UNIVERSIDADE DE SÃO PAULO

FACULDADE DE FILOSOFIA, LETRAS E CIÊNCIAS HUMANAS

DEPARTAMENTO DE LINGUÍSTICA

PROGRAMA DE PÓS-GRADUAÇÃO EM SEMIÓTICA E LINGUÍSTICA GERAL

PRISCILA LIMA PIRINI

CONSTRUÇÕES MARGINAIS EM GEORGIANO:

UMA ANÁLISE SOB A PERSPECTIVA DA LINGUÍSTICA

COGNITIVA. 
PRISCILA LIMA PIRINI

\section{CONSTRUÇÕES MARGINAIS EM GEORGIANO: UMA ANÁLISE SOB A PERSPECTIVA DA LINGUÍSTICA COGNITIVA.}

Dissertação apresentada ao Programa de Pós-Graduação em Semiótica e Linguística Geral da Faculdade de Filosofia, Letras e Ciências Humanas da Universidade de São Paulo, para obtenção do título de Mestre em Letras.

Área de concentração: Semiótica e Linguística Geral.

Orientador: Prof. Dr. Paulo Chagas de Souza. 
Autorizo a reprodução e divulgação total ou parcial deste trabalho, por qualquer meio convencional ou eletrônico, para fins de estudo e pesquisa, desde que citada a fonte.

Catalogação na Publicação

Serviço de Biblioteca e Documentação

Faculdade de Filosofia, Letras e Ciências Humanas da Universidade de São Paulo

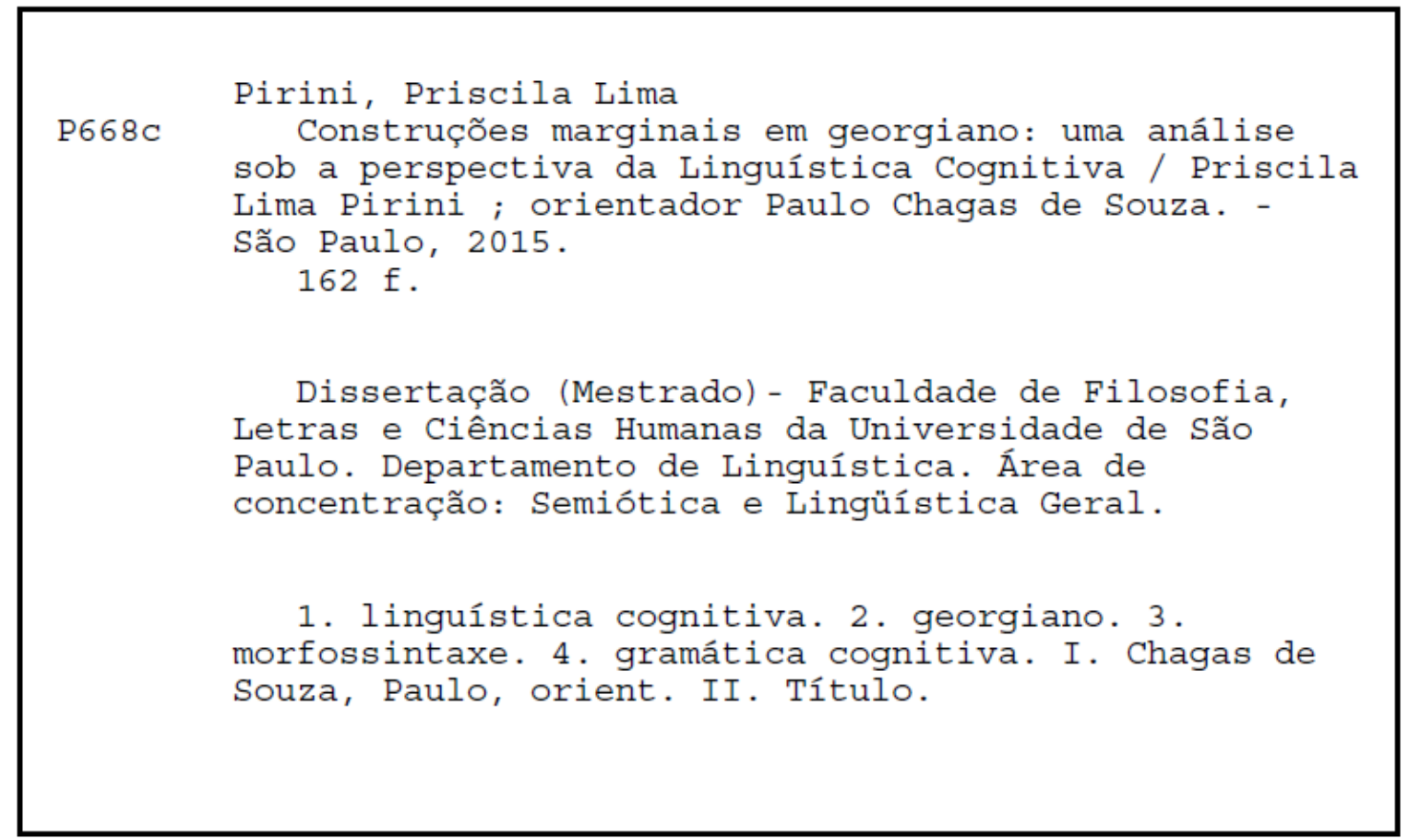


Nome: PIRINI, Priscila Lima.

Título: Construções marginais em georgiano: uma análise sob a perspectiva da Linguística Cognitiva.

Dissertação apresentada ao Programa de Pós-Graduação em Semiótica e Linguística Geral da Faculdade de Filosofia, Letras e Ciências Humanas da Universidade de São Paulo, para obtenção do título de Mestre em Letras.

Aprovada em:

Banca examinadora:

Prof. Dr.

Instituição:

Prof. Dr.

Instituição:

Prof. Dr.

Instituição: 


\section{AGRADECIMENTOS}

À Fundação de Amparo à Pesquisa do Estado de São Paulo (FAPESP) e Coordenação de Aperfeiçoamento de Pessoal de Nível Superior (CAPES), processo No 2014/03296-0, pela bolsa concedida que permitiu a dedicação exclusiva a esta pesquisa.

Ao meu orientador, Prof. Dr. Paulo Chagas de Souza, que tem me acompanhado desde a graduação, pelo apoio, confiança, aprendizado e acolhimento.

À instituição sede em que esta pesquisa se realizou, Faculdade de Filosofia, Letras e Ciências Humanas da Universidade de São Paulo, por possibilitar o desenvolvimento integral da pesquisa.

Aos professores do Departamento de Linguística, em especial, Prof. ${ }^{a}$ Dr. ${ }^{a}$ Ana Paula Scher, Prof. ${ }^{a}$ Dr. ${ }^{a}$ Evani de Carvalho Viotti e Prof. Dr. Marcos Fernando Lopes, por suas aulas, conselhos, estímulo e inspiração. Sem sua inestimável orientação, a realização plena deste trabalho não teria sido possível.

A todos que contribuíram de alguma forma para minha formação acadêmica como aluna e pesquisadora.

À minha família, pelo amor e compreensão em todos os momentos. 


\section{RESUMO}

PIRINI, P. L. Construções marginais em georgiano: uma análise sob a perspectiva da Linguística Cognitiva. 2015. 162 f. Dissertação (Mestrado) - Faculdade de Filosofia, Letras e Ciências Humanas da Universidade de São Paulo, São Paulo, 2015.

Diferentes agrupamentos de verbos, parte do que chamamos aqui de construções marginais, representam em georgiano um pequeno número de verbos que apresenta peculiaridades estruturais que se desviam, de um modo ou de outro, do padrão dominante representado por classes maiores de verbos. São nessas classes maiores que esses agrupamentos menores tradicionalmente acabam por ser inseridos, estando no limiar, diacrônica e sincronicamente, entre construções morfossintáticas maiores. Argumenta-se que, assim como em relação às classes verbais maiores e mais produtivas, esses grupos menores de verbos também revelam tendências bastante específicas presentes na língua, destacando-se por apresentar diferentes processos de significação. Em vista disso, com base no movimento teórico conhecido pelo amplo termo Linguística Cognitiva, procurouse compreender e explicar - fornecendo as necessárias relações entre construções que apontam para essas tendências menos e mais produtivas e prototípicas - de que forma mudanças formais vistas nesses grupos de verbos em particular - como mudanças argumentais, aumento ou apagamento de argumentos, mudança na marcação de caso de argumentos etc. - codificam e espelham maneiras e processos distintos de significação, e qual seria, consequentemente, a natureza dessas diferentes significações.

PALAVRAS-CHAVE: georgiano, linguística cognitiva, gramática cognitiva, construções marginais, morfossintaxe. 


\begin{abstract}
PIRINI, P. L. Marginal Constructions in Georgian: an analysis under the framework of Cognitive Linguistics. 2015. 162 f. Dissertação (Mestrado) - Faculdade de Filosofia, Letras e Ciências Humanas da Universidade de São Paulo, São Paulo, 2015.

Different groups of verbs, that we call here marginal constructions, represent in Georgian a limited number of verbs that have structural peculiarities that deviate in one way or another, from the dominant pattern represented by major verb classes in which they are traditionally classified, since they are at the threshold between major morphosyntactic constructions, diachronically and synchronically. It is argued that, compared to the largest and most productive verb classes, these smaller groups of verbs also reveal quite specific tendencies within the language, particularly by showing different meaning processes. Therefore, based on the theoretical framework known by the broad term Cognitive Linguistics, we sought to understand and explain - by providing the necessary relations between those constructions that point to less and more productive and prototypical tendencies - how formal changes seen in these verb groups in particular, e.g. changes in argument structure, increase or deletion of arguments, shifting in case marking of arguments etc., reflect and code distinct ways and processes of conceptualization, being able, therefore, to caracterize the nature of these different meanings.
\end{abstract}

KEY-WORDS: Georgian, cognitive linguistics, cognitive grammar, marginal constructions, morphosyntax. 


\section{LISTA DE FIGURAS}

Figura 1: Construção transitiva ativa (LANGACKER, 2008, p.385) ............................120

Figura 2: Construção passiva (LANGACKER, 2008, p.385) .......................................121

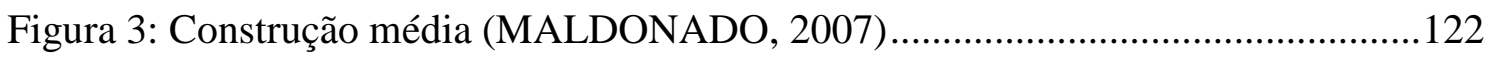

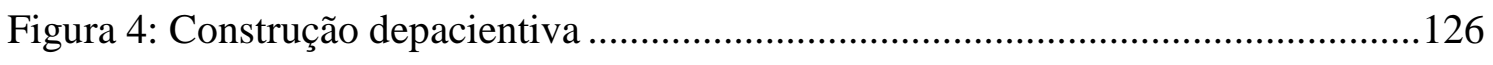

Figura 5: Construção bitransitiva (LANGACKER, 2008, p.242) ................................129

Figura 6: Verbos de transferência com dois participantes..........................................130 


\section{LISTA DE TABELAS}

Tabela 1: Marcação de caso de acordo com a classe e série. .26

Tabela 2: Sistema de screeves.

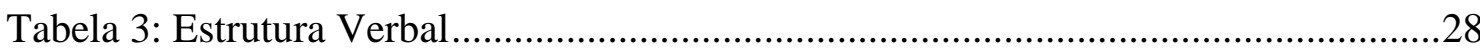

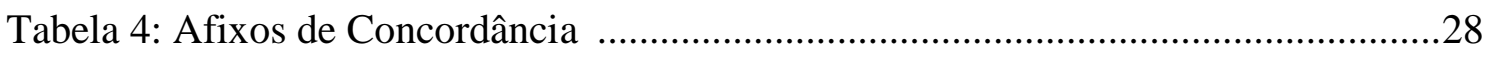

Tabela 5: Séries de concordância com o objeto indireto ..............................................29

Tabela 6: Concordância com objeto de terceira pessoa - Séries I do presente (padrão normal).

Tabela 7: Concordância com o sujeito de terceira pessoa (objeto indireto no dativo) Séries III do perfeito (padrão de inversão). .............................................................. 40

Tabela 8: Verbos lábeis (direto-indiretos) de Classe I (TUITE, 1998, p.37) 52 


\section{ABREVIATURAS}

1A, 3A, 1B, 3B, etc: conjunto $\mathrm{A}$ de afixos de concordância e conjunto $\mathrm{B}$ de afixos de concordância, lê-se 'primeira pessoa do conjunto A', 'terceira pessoa do conjunto B', etc., abreviaturas seguidas usualmente pelo caso gramatical do argumento, i.e., 3ANOM, 3BDAT, etc.;

AOR: aoristo;

COP: cópula;

DAT: dativo;

ERG: ergativo;

GEN: genitivo;

IMP: imperativo;

IMPERF: imperfeito;

INDIC: indicativo;

INST: instrumental;

INTR: intransitivo

NOM: nominativo;

NEG: negativo;

PERF: perfeito;

PI: infixo passivo (ou sufixo passivo)

PL: plural;

POSP: posposição;

POSS: possessivo

PV: preverbo;

SA: aumento de radical

SG: singular;

SM: marca de screeve;

ST: sufixo temático;

VPR: vogal pré-radical. 


\section{TRANSLITERAÇÃO}

\begin{tabular}{|c|c|c|c|}
\hline $\begin{array}{l}\text { Alfabeto } \\
\text { georgiano }\end{array}$ & Transliteração & $\begin{array}{l}\text { Alfabeto } \\
\text { georgiano }\end{array}$ & Transliteração \\
\hline$s$ & $\mathrm{a}$ & b & $\mathrm{s}$ \\
\hline 8 & $\mathrm{~b}$ & $\mathcal{O}$ & $\mathrm{t}^{\prime}$ \\
\hline 8 & g & $y$ & $\mathrm{u}$ \\
\hline$@$ & $\mathrm{~d}$ & O3 & $\mathrm{p}$ \\
\hline 9 & e & $\mathrm{d}$ & $\mathrm{k}$ \\
\hline 3 & $\mathrm{v}$ & & gh \\
\hline 8 & $\mathrm{z}$ & y & $\mathrm{q}$ \\
\hline o) & $\mathrm{t}$ & ฮ & $\mathrm{sh}$ \\
\hline $\mathrm{O}$ & $\mathrm{i}$ & $h$ & ch \\
\hline 3 & $\mathrm{k}^{\prime}$ & 3 & $\mathrm{c}$ \\
\hline m & 1 & $\partial$ & $\mathrm{dz}$ \\
\hline$\partial$ & $\mathrm{m}$ & 6 & $c^{\prime}$ \\
\hline 5 & $\mathrm{n}$ & $\mathfrak{F}$ & ch' \\
\hline$m$ & o & $b$ & $\mathrm{x}$ \\
\hline 3 & $\mathrm{p}^{\prime}$ & $x$ & $\mathrm{j}$ \\
\hline I & $\mathrm{zh}$ & 3 & $\mathrm{~h}$ \\
\hline m & $\mathrm{r}$ & & \\
\hline
\end{tabular}




\section{SUMÁRIO}

1. INTRODUÇÃ

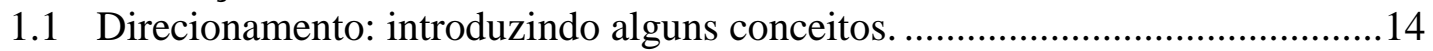

1.1.1 Embasamento teórico: Linguística Cognitiva ......................................15

1.1.2 Categorização na Linguística Cognitiva................................................17

1.1.3 Construções como pareamentos de forma e significado .........................18

1.1.4 Consequências das noções discutidas para a análise das construções

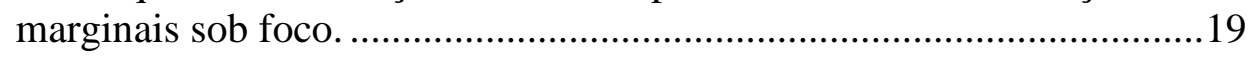

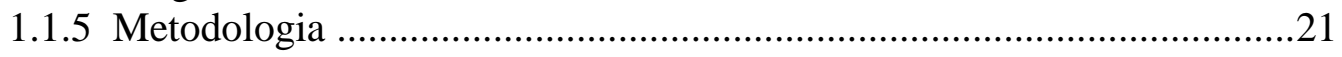

2. SISTEMA VERBAL: CLASSES VERBAIS EM GEORGIANO ........................24

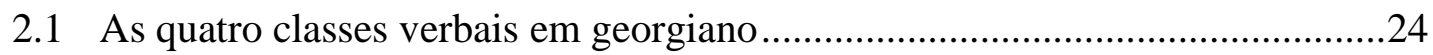

2.2 Classes: marcação de caso e concordância em georgiano ..................................26

2.2.1 Marcação de caso .......................................................................26

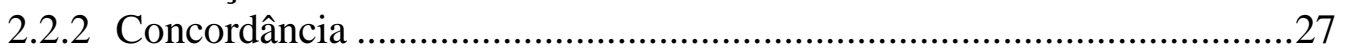

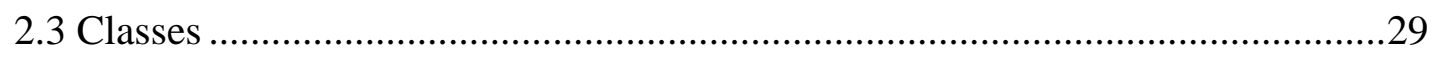

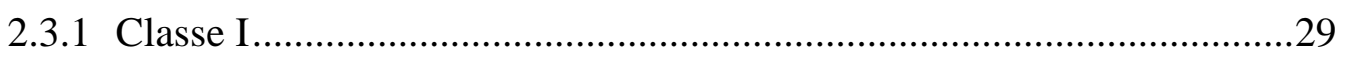

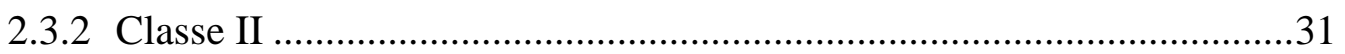

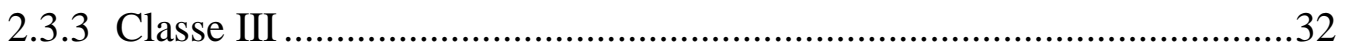

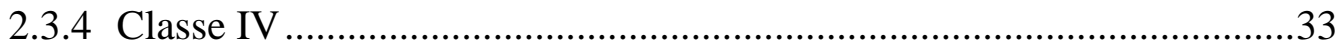

3. SISTEMA VERBAL: OUTRAS CARACTERÍSTICAS RELEVANTES ...........35

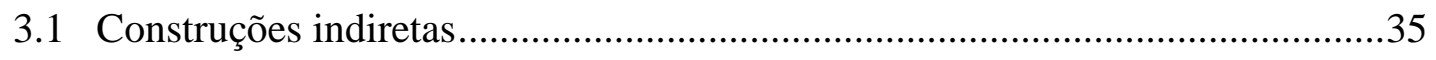

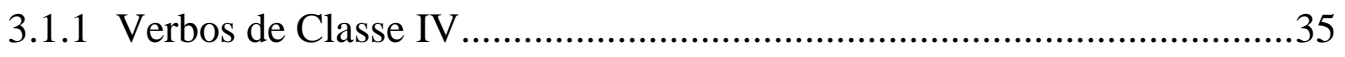

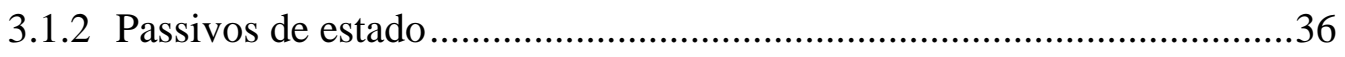

3.1.3 Construção dativa........................................................................... 37

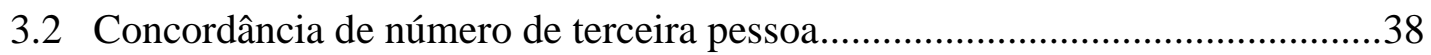

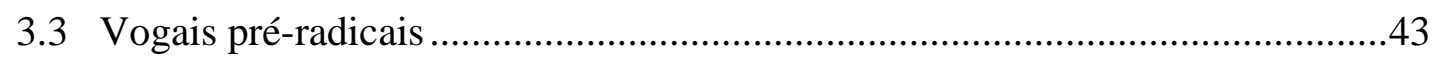

4. SISTEMA VERBAL: GRUPOS MARGINAIS DE VERBOS ...............................47

4.1 Verbos direto-indiretos (labiles) .................................................................47

4.1.1 Verbos de Classe II e verbos de Classe I .............................................47

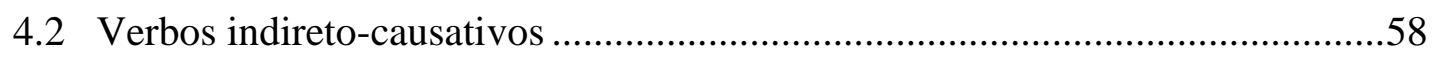

4.3 Verbos depoentes ...............................................................................6. 63

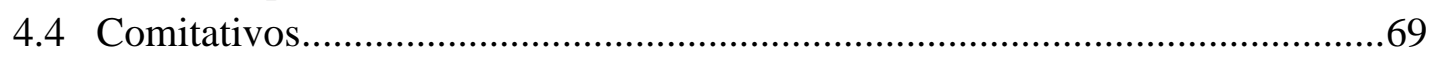

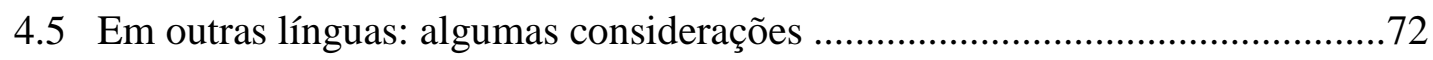

5. GRAMÁTICA COGNITIVA DE LANGACKER E ANÁLISE ALTERNATIVA DAS CONSTRUÇÕES MARGINAIS ...........................................................................79

5.1 Introdução a alguns conceitos básicos da Gramática Cognitiva (CG) de

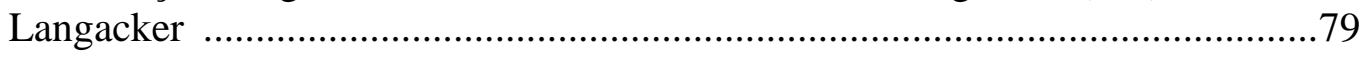

5.2 Construções marginais e contraste semântico ................................................ 81

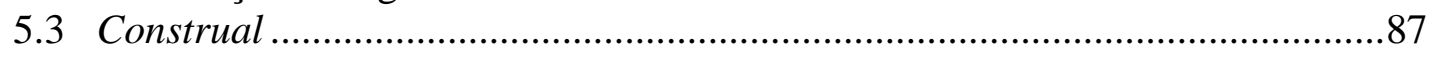

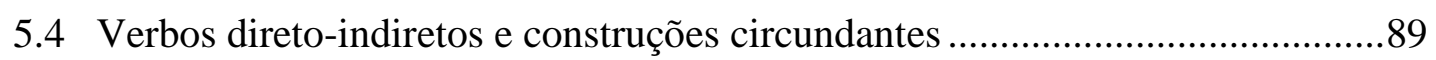

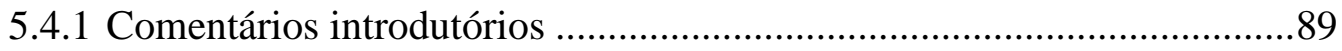


5.4.2 Construções marginais e construções circundantes ................................91

5.4.2.1 Verbos indireto-causativos

5.4.3 Contraste semântico e a importância da categoria semântica de volição

em georgiano

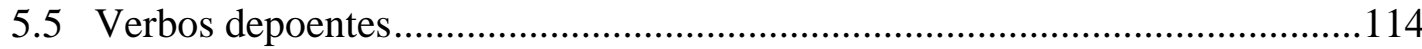

5.5.1 Vogal pré-radical e verbos comitativos ...............................................114

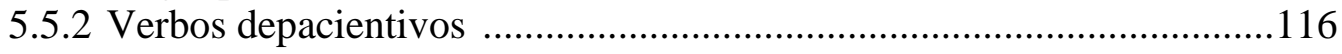

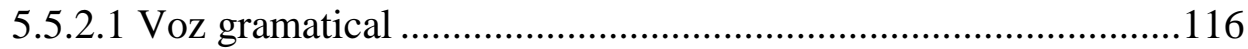

5.5.2.2 Arquétipos conceituais na CG e estratégias de codificação.......117

5.5.2.3 Construção depacientiva e construções circundantes ................119

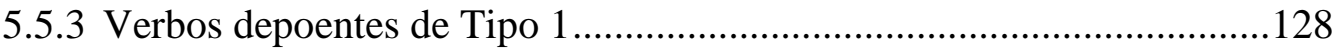

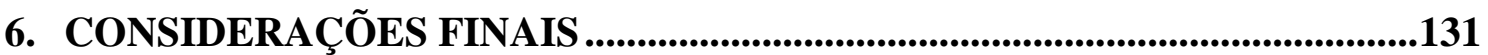

REFERÊNCIAS BIBLIOGRÁFICAS ...............................................................133

APÊNDICE: COMPILAÇÃO, PARA REFERÊNCIA, DOS EXEMPLOS DO

GEORGIANO UTILIZADOS AO LONGO DESTE TEXTO..................................141 


\section{INTRODUÇÃO}

\subsection{Direcionamento: introduzindo alguns conceitos.}

Partindo de uma análise estrutural da língua, tradicionalmente se dividem os verbos georgianos em classes, no geral, em quatro grandes classes. Cada classe vai ter associados a ela certos comportamentos gramaticais e usualmente uma morfologia em comum. Certos agrupamentos de verbos, no entanto, se desviam, de um modo ou de outro, do restante da classe, apresentando certas peculiaridades estruturais. Por essa razão, esses verbos são considerados como idiossincráticos ou como exceções relativamente aos verbos circundantes. Essa visão, argumenta-se, não é suficiente para dar conta da plena caracterização conceitual por detrás da aparente idiossincrasia estrutural - acredita-se, pelo contrário, que essa diferença estrutural se dá por reflexo de conceitualizações distintas que essas construções acabam por apresentar.

A aproximação restrita do sistema verbal através da noção de classes parte, sobretudo, de uma visão estrutural da língua, em que a estrutura é privilegiada em detrimento das significações que reflete.

Como é plenamente reconhecido pela literatura, a classificação dos verbos em classes em georgiano não é absoluta, tanto em termos formais, quanto semânticos. Ainda que classificações como essas tenham sua validade como a de representar generalizações na língua - o que, inclusive, pode indicar tendências em termos de construções envolvidas -, são pouco intuitivas e falham em revelar toda a complexidade conceitual por detrás da estrutura que é o ponto inicial para formar esse tipo de classificação.

Na Linguística Cognitiva (doravante LC) - movimento teórico no qual esta pesquisa se assenta - o significado ou o processo de conceitualização acionado pelas expressões linguísticas é o ponto de partida. A forma, não é para ser entendida como marginal, mas sim como uma das facetas de unidades simbólicas, a outra sendo o polo semântico. Dessa forma, qualquer unidade simbólica, de um item lexical a uma construção (uma questão apenas de gradação), é um pareamento de forma e significado. Por essa razão, a estrutura da língua reflete um rico aparato conceitual, dando pistas sobre o processo de significação que está sendo codificado.

Desse modo, se os verbos fossem aproximados de um ponto de vista de seu significado, i.e., das conceitualizações de eventos que codificam e das construções em 
que aparecem, poderíamos ter uma perspectiva mais intuitiva e clara de certos processos que ocorrem na língua e em seu sistema verbal.

E um exemplo são esses grupos de verbos sob foco, se fossem aproximados através dos eventos que codificam e, consequentemente, das construções em que estão aparecendo, veríamos que sua estrutura não é idiossincrática, e sim constitui um processo de significação em si que carrega similaridades e diferenças em relação às construções circundantes. E acreditamos que o processo codificado por esses verbos seria melhor capturado se partirmos, não de uma visão estrutural de classes, mas sim do ponto de vista de construções como pareamentos de forma e significado. A partir dessa premissa, é possível ganhar melhor entendimento desses grupos de verbos sob foco que serão aqui referidos pelo termo de construções marginais.

\subsubsection{Embasamento teórico: Linguística Cognitiva}

Este trabalho, como mencionado, tem como influência o movimento teórico conhecido pelo amplo termo Linguística Cognitiva, que evoca uma série de trabalhos desenvolvidos ao longo das últimas décadas por um conjunto de linguistas que dividem a visão de que a língua é parte da cognição humana e como tal, deve ser descrita e analisada com base em outros processos e habilidades cognitivas.

Essa premissa estende-se para a gramática da língua, na medida em que sua própria estrutura vai ser correlata a processos cognitivos como categorização, atenção, percepção, etc. Por conseguinte, cada construção vai refletir uma organização cognitiva particular, assim como distinções formais observadas na língua espelham igualmente diferenças conceituais (ACHARD, 1998, xi).

$\mathrm{O}$ que equivale a dizer que a gramática tem uma natureza inerentemente conceitual. Desse modo, contrária à visão de que a sintaxe constitui um componente autônomo, governada por princípios próprios e independente da semântica e do léxico, a Linguística Cognitiva vai sustentar, como pressuposto fundamental, que a gramática, assim como o léxico, constitui uma relação de forma $e$ significado.

O significado gerado por uma expressão linguística, por sua vez, é intrinsecamente cognitivo (TALMY, 2000a), i.e., é abarcado por uma forma mais geral de concepção à qual impõe certa seleção ou restrição (TALMY, 2000a, 4), em outras palavras, significado equivale à conceitualização, processo cognitivo pelo qual o significado de uma expressão 
linguística seria construído e que envolve não somente o conteúdo da situação ao qual se refere a expressão, mas também outros fatores como experiências e conhecimento prévios, contexto social, físico, etc. (EVANS \& GREEN, 2006, 162; LANGACKER, 2002: 2; 2008, 4).

Complementarmente, outro aspecto da conceitualização que desempenha papel central nos trabalhos, principalmente, de Langacker e Talmy, é aquele que concerne o modo como uma situação ou cena é construída e percebida, i.e., refere-se à nossa habilidade de estruturar o conteúdo dessa situação de diferentes modos, envolvendo diretamente o ponto de vista e percepção, além de pressupor certa escolha, daquele que é o sujeito da conceitualização (VERHAGEN, 2007). A diversidade de operações desse tipo que as línguas são capazes de codificar pode ser observada por classificações abrangentes originadas de linhas de pesquisa particulares, mas que convergem em resultados similares e complementares como, por exemplo, a classificação de Langacker (2008) - a saber, 'proeminência', 'especificidade', 'perspectiva' e 'foco' -; e a classificação feita por Talmy (2000a) - a saber, 'estrutura configuracional', 'perspectiva', 'atenção' e 'dinâmica de forças'. Categorias como essas correspondem ou espelham fenômenos e processos mais gerais da cognição e experiência humana.

Se o significado - visto como um processo cognitivo elaborado - torna-se um meio de acesso ao modo como pensamos e percebemos o mundo ao nosso redor, a gramática - vista como tendo significado inerentemente -, consequentemente, também passa a ser um meio de não só compreender melhor nossa cognição e a vasta variedade de conceitualizações que somos capazes de gerar, mas igualmente a forma como organizamos e estruturamos essas informações. E isso torna-se possível, sobretudo, por que a estrutura da língua nos dá meios de estruturar e codificar uma grande variedade dessas informações, nas palavras de Langacker:

\footnotetext{
Additionally, grammar allows us to construct and symbolize the more elaborate meanings of complex expressions (like phrases, clauses, and sentences). It is thus an essential aspect of the conceptual apparatus through which we apprehend and engage the world. And instead of being a distinct and self-contained cognitive system, grammar is not only an integral part of cognition but also a key to understanding it. (2008: 3 e 4)
}

Através, portanto, de sua sistematicidade, organização e dos padrões que apresenta, a estrutura da língua, sua gramática, torna-se um meio fundamental e essencial 
de se apreender o funcionamento e os mecanismos envolvidos na produção de significado e, por conseguinte, na cognição humana.

Um dos grandes interesses da Linguística Cognitiva que emerge, consequentemente, dessa concepção de língua, é o seu interesse em observar como a gramática codifica e organiza processos cognitivos mais gerais e estruturas conceituais complexas, incluindo operações que mobilizam estruturações distintas desse conteúdo conceitual. Parte desse amplo interesse é comum aos objetivos deste trabalho, na medida em que se pretende observar a significação codificada pela estrutura desses grupos de verbos, em outras palavras, um de nossos principais intuitos é justamente discutir como diferenças formais verificadas nesses verbos refletem ou codificam conceitualizações distintas.

\subsubsection{Categorização na Linguística Cognitiva}

Categorização é uma capacidade cognitiva básica em que somos capazes de apreender e identificar similaridades e diferenças em experiências, eventos ou objetos, tendo, dessa forma, a capacidade de agrupá-los de formas distintas. Assim, toda vez que nos deparamos com uma experiência ou entidade nova, a tendência é procurarmos uma forma de estabelecer relações com outras experiências que já conhecemos, seja modicando categorias já existentes, seja criando novas. A própria língua é uma ferramenta de categorização, de forma que podemos categorizar objetos ou experiências através dela.

Dois estudos relativos à categorização vindos da psicologia, desenvolvidos por Eleanor Rosch, tiveram um grande impacto na semântica cognitiva, as categorias de nível básico e a teoria de protótipos. Esses estudos vieram a mudar completamente, pelo menos sob a perspectiva da Linguística Cognitiva, a concepção clássica de categorização, em que as categorias são definidas por um conjunto de condições ou propriedades necessárias e suficientes, ou seja, uma entidade pertenceria àquela categoria se tivesse todas aquelas propriedades, as categorias, assim, seriam consideradas como tendo limites bem definidos, rígidos.

A teoria dos protótipos, em particular, vai mostrar que as categorias têm, pelo contrário, limites difusos ou fuzzy. As categorias não seriam definidas por um conjunto específico de propriedades, mas sim seriam estruturadas ao redor de protótipos, i.e., os membros considerados mais prototípicos daquela categoria. Por essa perspectiva, 
protótipos funcionam como pontos de referência para a classificação de instâncias não tão claras ou mais marginais à categoria.

Ainda em oposição à noção clássica de categorização, que pressupõe que os membros de uma dada categoria devam compartilhar um significado central, i.e., um significado ou conjunto de atributos comum a todos, está a noção de semelhança de família de Wittgenstein (TAYLOR, 1998). Para Wittgenstein, ainda que se possa associar à categoria certas similaridades de significado, não há um conjunto de propriedades comum a todos os membros de uma categoria, i.e., que todos necessariamente devam apresentar. Assim, os membros da categoria estariam ligados por uma rede de similaridades, em que alguns membros dividiriam certos atributos, outros dividiriam outros atributos, formando uma rede complexa de conexões (TAYLOR, 1998).

\subsubsection{Construções como pareamentos de forma e significado}

Uma construção é usualmente definida dentro da LC como um pareamento de forma e significado, sendo considerada como uma unidade básica da língua. Como nota Taylor (1998), construções também devem ser consideradas como a formar categorias em termos de prototipicidade, i.e., em que certas instanciações seriam mais prototípicas ou melhores exemplos daquela construção do que outras.

Uma construção, assim definida - i.e., como um pareamento de forma e significado -, pode apresentar efeitos de prototipicidade tanto em termos de forma quanto de significado, nas palavras de Taylor (1998):

A construction may be used to express meanings which differ to a greater or lesser extent from the central specification. Similarly, the items which fill the construction slots may diverge from the formal specification of the prototype.

Construções são aprendidas no contexto de uso, i.e., a partir de eventos de uso em toda sua especificidade de significado. Uma construção, portanto, é aprendida com base nos elementos que mais recorrentemente ocorrem nela, isto é, os lexemas não são apenas inseridos em slots, eles, assim como a própria construção, são aprendidos no contexto das construções em que aparecem. É a partir das similaridades apreendidas em eventos de uso que um esquema daquela construção, unidade mais abstrata e menos rica ou específica 
em detalhes, pode ser abstraído. O esquema de uma construção - uma abstração de instâncias mais específicas -, tendo sido arraigado na língua através de uso repetido, pode ser, inclusive, usado para sancionar novas expressões.

Quanto aos elementos que ocorrem em uma construção, há construções lexicalmente específicas, por exemplo, certas expressões idiomáticas, e há construções menos específicas em termos dos elementos que nela ocorrem - i.e., são abstrações de instâncias mais específicas que contêm itens lexicais particulares -, apenas especificando, por exemplo, que dado elemento seja um sintagma nominal ou especificando a presença de certos verbos, como um verbo transitivo. Dessa maneira, passam a formar esquemas abstraídos a partir de similaridades observadas em diferentes instâncias que apresentam aquele mesmo tipo de configuração (TAYLOR, 1998).

E como foi mencionado, assim como uma construção tem seu esquema abstraído a partir dos elementos que recorrente e prototipicamente aparecem nela, um verbo ou os sentidos associados a ele são abstraídos a partir das construções em que esse verbo ocorre. Dessa forma, verbos são aprendidos no contexto das construções em que aparecem e viceversa, e a partir do arraigamento e convencionalização do uso do verbo em determinada construção é que se pode dizer que o verbo tem o sentido associado àquela construção. Assim, aquela construção, ou significado associado à construção, faz parte dos sentidos associados ao lexema verbal através de esquematização.

Portanto, um item lexical, como um verbo, não é aprendido em isolamento, pelo contrário, sua aquisição se dá através das construções em que ocorre, tornando-se uma unidade através de arraigamento e convencionalização, i.e., sendo abstraído de eventos de uso a partir de similaridades apreendidas. Assim, um verbo, por exemplo, pode ser referido como 'transitivo' apenas por ser usado prototipicamente em construções transitivas que na LC, aliás, é definida conceitualmente, sendo a noção de transitividade uma questão de gradação.

\subsubsection{Consequências das noções discutidas para a análise das construções marginais sob foco.}

As noções discutidas anteriormente de categorização, prototipicidade e de construções como pareamentos de forma e significado serão a base para a abordagem que 
daremos a esses diferentes agrupamentos de verbos. Como mencionado, consideramos que esses verbos não representam uma idiossincrasia, mas sim sua diferença estrutural é reflexo de conceitualizações distintas. Argumenta-se que, assim como em relação às construções circundantes mais produtivas, esses grupos menores de verbos também revelam tendências - ainda que menos salientes e produtivas - bastante específicas presentes na língua, destacando-se por apresentar diferentes processos de significação. ${ }^{1}$

O ponto inicial, portanto, consiste em vermos esses verbos no contexto dessas construções em que aparecem, identificando o processo de significação que está sendo acionado, e isso será feito em contraste com as construções circundantes. Nossa análise, portanto, se restringirá a essas construções marginais que englobam diferentes grupos de verbos, cada qual com suas peculiaridades: os que chamamos de verbos direto-indiretos, causativos-indiretos, depacientivos e outros pequenos grupos de verbos depoentes de Classe II como são referidos tradicionalmente. Em relação a cada um desses grupos, será feita a análise pensando no contraste com construções circundantes mais produtivas, no caso de verbos direto-indiretos e causativos-indiretos, com as construções que serão referidas pelo amplo termo de construções diretas e construções indiretas, e no caso de verbos depacientivos com certas construções diretamente relacionadas envolvendo voz.

E esse tratamento que daremos a esses grupos de verbos envolve as noções que discutimos anteriormente de construções como pareamentos de forma e significado, categorização e prototipicidade. Nossa aproximação a esses grupos de verbos se dá considerando-os como parte de construções que refletem diferentes conceitualizações de eventos, assim sendo, a aproximação não ocorre a partir de termos puramente estruturais, mas sim a partir da noção de construções como pareamentos de forma e significado, a estrutura diferenciada desses verbos sendo apenas reflexo de um elaborado processo de significação.

\footnotetext{
${ }^{1}$ A noção de produtividade em modelos baseados no uso, e utilizada aqui, está relacionada ao grau de arraigamento de um esquema e frequência de tipo. Frequência de tipo é a frequência de determinado padrão - em contraste com a frequência de token que é a frequência de determinado item na língua -, quanto maior for a frequência de ocorrência de instâncias que correspondem a determinado esquema, mais arraigado esse esquema será e maior seu grau de produtividade na língua. Assim, de acordo com Croft \& Cruse (2004), a produtividade (e arraigamento) de uma construção seria proporcional ao número de instâncias daquela construção em qualquer nível de especificidade e ao grau de aproximação semântica e formal dessas instâncias em relação ao esquema. Por essa perspectiva, as construções aqui referidas como marginais em que ocorrem um número restrito de verbos (por exemplo, os verbos referidos como direto-indiretos) podem ser consideradas como menos produtivas, isto é, haveria uma menor ocorrência de instâncias que correspondem à construção comparativamente às construções circundantes em que a frequência de instâncias é maior, havendo um grande número de verbos na língua que aparecem nessas construções (por exemplo, os verbos ditos de Classe IV pela gramática tradicional).
} 
Com a noção de construções em mente, consideramos que, assim como outros elementos na língua, construções também mostram efeitos de categorização e prototipicidade. Sob essa perspectiva, construções formam com outras construções categorias complexas com efeitos de prototipicidade, em que certas instâncias são mais prototípicas e outras mais marginais, podendo ocorrer extensões a partir do protótipo tanto a partir de sua forma quanto de seu significado, como discutido acima.

Dessa forma, acredita-se que as construções que referimos como marginais constituem, em relação às construções circundantes e mais prototípicas, extensões destas, em alguns casos, tanto em termos de forma quanto de significado. Por exemplo, argumenta-se que as chamadas aqui de construções indiretas formam uma categoria complexa na língua que, acreditamos, representa uma tendência, no sentido de representar formas particulares de codificar certas significações de certa maneira na língua. Certas construções indiretas seriam mais prototípicas que outras, nesse caso, supomos que as construções com verbos ditos de Classe IV pela gramática tradicional constituiriam as mais prototípicas, enquanto certas construções marginais sob foco, nesse caso citado, as que ocorrem com verbos direto-indiretos, seriam extensões desse protótipo, sendo mais marginais dentro da categoria de construções indiretas na língua.

\subsubsection{Metodologia}

Como foi mencionado em seções anteriores, a análise e descrição na literatura linguística sobre a língua tem uma base fundamentalmente estrutural, em que o ponto de partida para a análise é, na maior parte, a estrutura. Nosso intuito é oferecer uma análise alternativa, com base na LC, a uma pequena parcela do sistema verbal. Devido justamente à necessidade de delimitar nosso objeto de estudo, nos restringiremos às construções marginais sob foco em contraste às construções circundantes e incluindo outros aspectos do sistema verbal que forem pertinentes para a descrição dessas construções e argumentação da análise. Assim, muitos aspectos do sistema verbal, como ficará evidente, ficarão sem ser abordados em nossa análise, nossa contribuição, desse modo, consistindo em uma tentativa inicial e modesta de lançarmos, ao fim, um olhar diferente para a língua e seu complexo sistema verbal.

Para que possamos oferecer uma aproximação alternativa a esses grupos de verbos, serão revistos nos primeiros capítulos, além da divisão tradicional dos verbos em 
classes - o que inclui os grupos de verbos sob foco e seu tratamento -, alguns aspectos do sistema verbal georgiano que serão relevantes para a nossa discussão. Com essa exposição e a partir dela, temos o intuito de oferecer uma base para o entendimento de como o sistema verbal georgiano é tratado na literatura linguística da língua que, acreditamos, é essencial para se ganhar uma visão das questões e alcances explicativos desenvolvidos por essa tradição.

E reconhecendo a importância e pertinência dessas análises desenvolvidas que, de uma forma ou de outra, formam a base para os estudos da língua, procuraremos desenvolver essa exposição e discussão de forma a atentar para certas explicações e generalizações alcançadas que serão aproveitadas e usadas em nossa própria aproximação aos grupos de verbos sob questão.

Dessa forma, nos capítulos iniciais será feita essa exposição de forma a proporcionar uma visão geral do sistema verbal como é usualmente descrito na literatura e de forma a discutir e dirigir a atenção aos aspectos que serão utilizados na análise que será conduzida com base na LC nos capítulos que seguirão. Assim, será feita uma transição gradativa de uma visão à outra, para que, ao fim, possamos demonstrar através de nossa análise como é possível e viável abordarmos as construções marginais sob foco de maneira alternativa, vendo-as sob o ponto de vista das significações que codificam e não de uma visão puramente formal de classes.

No que diz respeito aos dados utilizados no presente estudo, o levantamento bibliográfico proposto por esta pesquisa abrange a soma de dados que foi necessária para dar embasamento à análise pretendida. Ademais, como auxílio ao levantamento de um dado específico ou pontual no decorrer da pesquisa, recorreu-se à eliciação por meio de contato pessoal com falantes nativos. Esse contato, também por uma questão de viabilidade e disponibilidade, foi obtido de modo informal por meios de comunicação à distância como e-mail.

Os dados, portanto, foram retirados sobretudo da literatura linguística que tem tratado, por diferentes motivações, das classes verbais em georgiano como um todo, o que acaba por abarcar os grupos de verbos aos quais temos nos referido, a saber: verbos direto-indiretos, incluindo aqueles tradicionalmente classificados como de Classe III, II e I: Aronson \& Kiziria (1999); Cherchi (1997); Hewitt (1987, 1995); Holisky (1981); Tschenkeli (1958a, b); Tuite (1987, 1998, 2009); verbos indireto-causativos: Cherchi (1997); Holisky (1981); Tuite (1998, 2009); depacientivos e agentivos de Classe II: 
Aronson \& Kiziria (1999); Amiridze (2006); Harris (1981, 1985); Tuite (1998, 2002, 2007, 2009).

Como a intenção não é listar esses verbos exaustivamente - tarefa que, inclusive, já foi feita por alguns dos autores mencionados em relação a alguns desses grupos de verbos -, uma pequena soma de verbos proveniente de cada uma dessas classes de verbos, retirada dessa literatura linguística especificada, foi suficiente para dar embasamento à análise proposta por este trabalho.

Os dados retirados, portanto, de outros autores foram explicitamente indicados, tendo a referência indicada logo abaixo do exemplo ou conjunto de exemplos. $\mathrm{Na}$ ausência dessa indicação, o exemplo ou dado foi obtido por meio de eliciação com falantes nativos.

Ao final desta dissertação, foi acrescentado um apêndice com a compilação de todos os exemplos do georgiano utilizados ao longo deste texto, indicando-se a seção e página em que inicialmente aparecem para facilitar a referência e retomada. 


\section{SISTEMA VERBAL: CLASSES VERBAIS EM GEORGIANO}

\subsection{As quatro classes verbais em georgiano.}

Costuma-se, tradicionalmente, dividir os verbos em georgiano em 'classes', usualmente quatro, representando propriedades comuns entre esses verbos. Apesar de os rótulos mudarem dependendo do autor, as classificações são basicamente similares nas distinções e limites que propõem, principalmente em relação aos critérios formais.

Todavia, em relação às propriedades semânticas e sintáticas atribuídas a cada classe, nem sempre o mesmo consenso é compartilhado. Os parâmetros por vezes empregados para distinguir entre uma classe e outra, além de suas características morfológicas, variam entre voz, transitividade ou ambos. Na gramática tradicional de Shanidze (1973), classificam-se os verbos em ativos, passivos e médios, esses últimos subdivididos em médio ativos e médio passivos. Hewitt (1995) agrupa os verbos em transitivos, intransitivos, mediais, indiretos e estativos. De forma similar, Tschenkeli (1958) separa os verbos em transitivos, médios, passivos e indiretos. Aronson (1992) faz uma classificação de verbos em quatro conjugações que se assemelha à distinção feita por Tschenkeli. Harris (1981), por sua vez, também divide os verbos em quatro classes, definindo-as inicialmente apenas com base em distinções morfológicas diretas.

E como mencionado, o principal problema inerente a esse tipo de classificação e terminologia, e frequentemente notado pelos autores, é a não uniformidade de traços sintáticos e semânticos atribuídos aos verbos em cada classe (cf. AMIRIDZE (2006); HEWITT (1995); TUITE (1998, 2006)), podendo ocasionar certa interpretação tendenciosa. À guisa de exemplo, nem todos os verbos agrupados na classe de 'transitivos' são uniformemente transitivos, havendo também verbos sintaticamente intransitivos (HEWITT, 1995).

Classificações como essas, portanto, podem a priori ser tomadas como categorizações puramente formais, i.e., levam em conta, sobretudo, características morfológicas em comum. Por consequência, levantariam certa divergência em relação às propriedades semânticas e sintáticas que corresponderiam a cada classe. Assim, no que diz respeito, principalmente, a esses dois últimos aspectos, sintáticos e semânticos, distinções pouco nítidas ou definíveis podem ser estabelecidas em determinados momentos. 
No entanto, classificações tais como aquelas citadas, não são de todo arbitrárias e sem significado, se tomadas como generalizações na língua e não como distinções absolutas, podem ser válidas para o entendimento de certos processos e tendências presentes na língua.

Harris (1981), por exemplo, apesar de partir de uma definição formal dessas classes - e sem deixar de reconhecer a existência de exceções em cada classe - argumenta que podem ser identificados traços semânticos e sintáticos em cada classe, o que as tornaria não arbitrárias, dispensando a necessidade de se listar os verbos que pertenceriam a cada uma.

Como discutido pela autora, a coalescência de traços semânticos e sintáticos em cada classe envolveria seu argumento de que a língua apresenta uma marcação ativa/estativa, i.e., verbos intransitivos têm uma marcação distinta a depender do grau de agentividade ou controle do sujeito sobre a ação. Verbos intransitivos que denotam ações menos agentivas têm seu sujeito marcado da mesma forma que objetos diretos de verbos transitivos, enquanto verbos intransitivos que denotam ações mais agentivas e controláveis têm seus sujeitos marcados da mesma forma que sujeitos de verbos transitivos. A partir dessa premissa, traça as seguintes generalizações: a Classe I seria composta em sua maioria por verbos transitivos e ativos; a Classe II seria formada por verbos intransitivos com sujeitos marcados da mesma forma que objetos diretos de transitivos de Classe I, caracterizados por uma semântica inativa ou passiva; a Classe III, seria composta por verbos intransitivos com sujeitos marcados da mesma forma que sujeitos de verbos transitivos de Classe I, sendo caracterizados por uma semântica ativa ou agentiva; a Classe IV, por fim, seria formada por verbos indiretos, apresentando sujeitos caracterizados por serem experienciadores e de pouco controle sobre a ação.

Por essa perspectiva, classificações como essa, se tomadas apenas como formas de se identificar certas generalizações na língua, podem constituir um modo de se observar certos processos e tendências presentes na língua.

Dessa forma, ainda que esses tipos de divisões, sejam quais forem os critérios utilizados, não representem limites precisos ou indiscutíveis tanto quanto se almeja tradicionalmente - que parte de uma noção estrutural da língua -, podem apontar, de qualquer forma, que há no comportamento dessas classes ou grupos de verbos padrões que evidenciam fortes tendências presentes na língua, i.e., formas particulares de se codificar certas significações de certa maneira na língua. 
A seguir, serão então revistos alguns aspectos do sistema verbal, além da classificação dos verbos em classes mencionada acima, a partir da visão tradicional em que se assenta a descrição da língua.

\subsection{Classes: marcação de caso e concordância em georgiano}

\subsubsection{Marcação de caso}

Uma visão geral da marcação de caso em georgiano pode ser vista na Tabela 1. Os padrões de marcação de caso variam de acordo com a classe do verbo e com a Série, termo proveniente do georgiano e que agrupa um conjunto de diferentes screeves - termo também adaptado do georgiano, ' $m c$ ' $k$ 'rivi', constituindo paradigmas de formas verbais flexionadas em número e pessoa e que refletem, morfologicamente, uma formação de radical em comum e, sintaticamente, um padrão de marcação de caso em comum (TUITE, 1998; WIER, 2008).

\begin{tabular}{|c|c|c|c|c|c|c|c|c|c|}
\hline & \multicolumn{3}{|c|}{ Séries I - Presente } & \multicolumn{3}{c|}{ Séries II - Aoristo } & \multicolumn{3}{c|}{ Séries III - Perfeito } \\
\hline & SUJ & OD & OI & SUJ & OD & OI & SUJ & OD & OI \\
\hline Classe I & NOM & DAT & DAT & ERG & NOM & DAT & DAT & NOM & OBL \\
\hline Classe II & NOM & - & DAT & NOM & - & DAT & NOM & - & DAT \\
\hline Classe III & NOM & (DAT) & DAT & ERG & (NOM) & DAT & DAT & (NOM) & OBL \\
\hline Classe IV & DAT & NOM & (OBL) & DAT & NOM & (OBL) & DAT & NOM & (OBL) \\
\hline
\end{tabular}

Tabela 1: Marcação de caso de acordo com a classe e série.

Como pode ser observado pela Tabela 1, não há uma correlação única entre os casos e relações gramaticais. Casos, por exemplo, como o nominativo e dativo podem marcar tanto sujeitos quanto objetos dependendo da classe do verbo e de características aspectuais e temporais expressas pelo verbo (AMIRIDZE, 2006).

Nas Séries I do Presente, o sujeito é marcado pelo nominativo e o objeto pelo dativo, nas Séries III do Perfeito e com os verbos de Classe IV em todas as Séries, há o que chamam de inversão, o objeto passa a ser marcado pelo nominativo e o sujeito pelo dativo.

A Tabela 2, a seguir, ilustra a divisão de cada Série em screeves, as Séries I do Presente sendo subdivididas em duas subséries, do presente e do futuro: 


\begin{tabular}{|c|c|c|}
\hline \multirow{2}{*}{ Séries I - Presente } & \multicolumn{2}{|c|}{ Screeve } \\
\cline { 2 - 3 } & Subsérie do Presente & Subsérie do Futuro \\
\cline { 2 - 3 } & Presente & Futuro \\
\cline { 2 - 3 } & Imperfeito & Condicional \\
\hline \multirow{2}{*}{ Séries II - Aoristo } & \multicolumn{2}{|c|}{ Subjuntivo Presente } \\
\hline \multirow{2}{*}{ Séries III - Perfeito } & \multicolumn{2}{|c|}{ Optativo } \\
\cline { 2 - 2 } & \multicolumn{2}{|c|}{ Perfeito } \\
\cline { 2 - 2 } & \multicolumn{2}{|c|}{ Mais-que-perfeito } \\
\hline
\end{tabular}

Tabela 2: Sistema de screeves.

A ergatividade cindida no georgiano - para aqueles a favor da tese de que a língua apresentaria padrões de ergatividade -, teria sua manifestação nas Séries II do Aoristo, verbos de Classe I, na maioria transitivos, têm o sujeito marcado pelo caso ergativo e o objeto pelo caso nominativo. Já verbos de Classe II, normalmente intransitivos, têm seu sujeito marcado com o caso nominativo, mesmo caso usado para marcar o objeto de verbos de Classe I nas Séries II.

Dessa forma, além dos casos de inversão que afetam tanto a marcação de caso quanto a concordância, o padrão de caso nas Séries II também altera os valores entre caso e relações gramaticais, o caso nominativo, por exemplo, que marcava nas Séries I o sujeito de verbos transitivos e intransitivos, passa a marcar nas Séries II o objeto de transitivos e sujeito de intransitivos de Classe II (mas não de Classe III).

\subsubsection{Concordância}

A estrutura do verbo em georgiano é morfologicamente complexa. O verbo concorda com o sujeito, o objeto direto e em alguns casos com o objeto indireto, além de carregar marcas de aspecto, tempo, passividade, causatividade, dentre outras.

Basicamente, a estrutura morfológica que pode compor um verbo em georgiano pode ser visualizada na Tabela 3. Cada posição indicada por um número representa o que se chama de slots, assim, quando presentes na estrutura de um dado verbo, possuem uma posição fixa antes ou depois da raiz verbal como indicado. 


\begin{tabular}{|c|c|c|c|c|c|c|c|}
\hline 1 & 2 & 3 & 4 & 5 & 6 & 7 & 8 \\
\hline Preverbo & $\begin{array}{c}\text { Prefixo de } \\
\text { Concordância }\end{array}$ & $\begin{array}{c}\text { Vogal Pré- } \\
\text { Radical }\end{array}$ & RAIZ & $\begin{array}{c}\text { Sufixo } \\
\text { Passivo }\end{array}$ & $\begin{array}{c}\text { Sufixo } \\
\text { Temático }\end{array}$ & $\begin{array}{c}\text { Marca de } \\
\text { Tempo/Modo }\end{array}$ & $\begin{array}{c}\text { Sufixo de } \\
\text { Concordância }\end{array}$ \\
\hline
\end{tabular}

Tabela 3: Estrutura Verbal

Nos slots número 2 e 8 aparecem os afixos responsáveis pela concordância. É por meio de uma combinação de prefixos e sufixos que se dá a concordância com sujeito e objeto.

A distribuição dos conjuntos de afixos vai depender da estrutura argumental do verbo, da classe verbal, de características aspectuais e temporais do verbo e por vezes é idiossincrática ao verbo (AMIRIDZE, 2006).

A Tabela 4 mostra os afixos de concordância em georgiano. Para evitar denominar os dois conjuntos de marcas de ‘sujeito' e 'objeto' respectivamente - identificação, aliás, feita em alguns trabalhos - optou-se por seguir Amiridze (2006) e apenas identificar os conjuntos de afixos como A e B. O principal motivo, como ficará evidente, é que os afixos, tanto de um conjunto quanto de outro, não são usados exclusivamente para marcar sujeito e objeto respectivamente.

\begin{tabular}{|c|c|c|}
\hline \multicolumn{3}{|c|}{ Conjunto A } \\
\hline & Singular & Plural \\
\hline $1^{\mathrm{a}}$ pessoa & $\mathrm{v}-$ & $\mathrm{v}-\mathrm{t}$ \\
\hline $2^{\mathrm{a}}$ pessoa & $\varnothing$ & $-\mathrm{t}$ \\
\hline $3^{\mathrm{a}}$ pessoa & $-\mathrm{s} / \mathrm{a} / \mathrm{o}$ & -en/es/nen, etc \\
\hline \multicolumn{3}{|c}{ Tabela $4 \cdot$ Afixos }
\end{tabular}

\begin{tabular}{|c|c|c|}
\hline \multicolumn{3}{|c|}{ Conjunto B } \\
\hline & Singular & Plural \\
\hline $1^{\mathrm{a}}$ pessoa & $\mathrm{m}-$ & $\mathrm{gv}-$ \\
\hline $2^{\mathrm{a}}$ pessoa & $\mathrm{g}-$ & $\mathrm{g}-\mathrm{t}$ \\
\hline $3^{\mathrm{a}}$ pessoa & $\mathrm{s} / \mathrm{h} / \varnothing-$ & $\mathrm{s} / \mathrm{h} / \varnothing-\mathrm{t}$ \\
\hline
\end{tabular}

Tabela 4: Afixos de Concordância

A alternância entre as marcas de terceira pessoa do conjunto A é determinada por tempo/aspecto e classe do verbo.

O conjunto B engloba os afixos que usualmente marcariam tanto o objeto direto quanto o indireto. A única diferença entre as marcas de concordância de objeto direto e indireto no verbo estaria na terceira pessoa do singular e plural, em que o objeto direto teria uma marca zero para singular e plural, enquanto que o objeto indireto teria, para plural e singular, além da marca zero, duas outras marcas que se alternariam $(-s /-h)$, sendo fonologicamente previsíveis.

No entanto, no georgiano moderno, essas marcas de objeto indireto $(-s /-h)$ não são mais usadas consistentemente (cf. HARRIS, 1981; HEWITT, 1995), apagando a única diferença que haveria entre as marcas de concordância de objeto direto e indireto no verbo. Por esse motivo, não se costuma representar em dois conjuntos distintos as marcas de objeto direto e indireto. 
Quando há, no verbo, as vogais pré-radicais servindo para indicar a presença ou adição de um objeto indireto (ver seção 3.3 sobre a vogal pré-radical), a concordância com esse objeto indireto é feita por meio da vogal pré-radical no slot número 3 em adição às marcas do conjunto $\mathrm{B}$. Tradicionalmente, considera-se haver quatro conjuntos ou séries de marcas de concordância com o objeto indireto, série- $u$, série- $e$, série- $a$ e série- $h$. A única diferença entre as três primeiras é o uso de vogais pré-radicais distintas, de resto as marcas são as mesmas para as quatro séries, i.e., além da vogal pré-radical, são usadas conjuntamente as marcas do conjunto B.

\begin{tabular}{|c|c|c|c|c|c|c|c|c|}
\hline & \multicolumn{2}{|c|}{ Série- $h$} & \multicolumn{2}{c|}{ Série- $u$} & \multicolumn{2}{c|}{ Série- $a$} & \multicolumn{2}{c|}{ Série-e } \\
\hline & Singular & Plural & Singular & Plural & Singular & Plural & Singular & Plural \\
\hline $1^{\mathrm{a}}$ pessoa & $\mathrm{m}-$ & $\mathrm{gv-}$ & $\mathrm{m}-\mathrm{i}-$ & $\mathrm{gv-i}-$ & $\mathrm{m}-\mathrm{a}-$ & $\mathrm{gv-a}-$ & $\mathrm{m}-\mathrm{e}-$ & $\mathrm{gv-e}-$ \\
\hline $2^{\mathrm{a}}$ pessoa & $\mathrm{g}-$ & $\mathrm{g}-\mathrm{t}$ & $\mathrm{g}-\mathrm{i}-$ & $\mathrm{g}-\mathrm{i}-\mathrm{t}$ & $\mathrm{g}-\mathrm{a}-$ & $\mathrm{g}-\mathrm{a}-\mathrm{t}$ & $\mathrm{g}-\mathrm{e}-$ & $\mathrm{g}-\mathrm{e}-\mathrm{t}$ \\
\hline $3^{\mathrm{a}}$ pessoa & $\mathrm{s} / \mathrm{h} / \varnothing-$ & $\mathrm{s} / \mathrm{h} / \varnothing-\mathrm{t}$ & $\mathrm{u}-$ & $\mathrm{u}-\mathrm{t}$ & $\mathrm{a}-$ & $\mathrm{a}-\mathrm{t}$ & $\mathrm{e}-$ & $\mathrm{e}-\mathrm{t}$ \\
\hline
\end{tabular}

A inversão que ocorre em verbos de Classe IV e nas Séries III do perfeito em verbos de Classe I e III também se reflete na concordância. Os afixos do conjunto A que marcam o sujeito nas Séries I, nas Séries III e em verbos de Classe IV, passam a marcar o objeto, enquanto os afixos do conjunto B passam a marcar o sujeito nas Séries III e em verbos de Classe IV. Por essa razão, é preferível denominar os conjuntos de afixos apenas como A e B, e não como afixos de sujeito e objeto respectivamente, como se encontra em alguns trabalhos.

O aparente padrão de ergatividade observado nas Séries II - diferente dos casos de inversão em que tanto a marcação de caso quanto a concordância são afetadas - se refletiria apenas na marcação de caso e não na concordância, i.e., tanto sujeitos de transitivos quanto de intransitivos acionam os afixos do conjunto A nas Séries I e Séries II, enquanto o objeto de transitivos aciona os afixos do conjunto B.

\subsection{Classes}

\subsubsection{Classe I}


Morfologicamente, verbos de Classe I são caracterizados pelas seguintes propriedades (cf. HARRIS, 1981 e HOLISKY, 1979): adição de um preverbo no tempo futuro - distinguindo-o do presente - e no aoristo (observe a presença do preverbo $a$ - na sentença em (1b) no aoristo das Séries II); o afixo de concordância $-s$ é utilizado para marcar, no verbo, o sujeito na terceira pessoa do singular (cf. a-shen-eb-s 'ele constrói') e o afixo -en para marcar, no verbo, o sujeito na terceira pessoa do plural no futuro e presente (observe a sentença em (1a) no presente); no aoristo, o afixo de concordância es marca o sujeito na terceira pessoa do plural no verbo (observe a sentença em (1b)).

(1a) kal-eb-i saxl-s a-shen-eb-en. mulher-PL-NOM casa-DAT VPR-construir-ST-3ANOM.PL ${ }^{2}$ As mulheres estão construindo uma casa.

(1b) kal-eb-ma saxl-i a-a-shen-es. mulher-PL-ERG casa-NOM PV-VPR-construir-3AERG.PL.AOR.INDIC As mulheres construíram a casa.

(1c) kal-eb-s turme saxl-i a-u-sheneb-i-a-t. mulher-PL-DAT aparentemente casa.NOM PV-VPR-construir-SM-3ANOM-PL.DAT As mulheres aparentemente construíram a casa.

Ademais, verbos de Classe I seguem os padrões de marcação observados na Tabela 1, i.e., têm seu sujeito marcado pelo caso ergativo nas Séries II do Aoristo e sofrem inversão na marcação de caso e concordância nas Séries III do Perfeito.

Dentre os verbos que poderiam ser considerados prototípicos de Classe I - i.e., verbos que usualmente denotam eventos de dois ou mais participantes com sujeitos agentivos, agindo volitivamente -, encontram-se verbos transitivos como o exemplificado acima $a$-shen-eb-s 'construir', formado, como é característico de alguns verbos dessa classe, com a vogal pré-radical - $a$-, ou 'versão neutra' como é chamada, e com o sufixo temático -eb-; verbos ditransitivos como $a$-chuk-eb-s 'dar algo a alguém', com um objeto direto e um objeto indireto, este ficando no dativo nas Séries I e II, e nas Séries III, sendo marcado por uma posposição; e verbos causativos como $a$-shen-eb-in-eb-s 'fazer alguém

\footnotetext{
${ }^{2}$ As glosas usadas no presente trabalho referentes aos exemplos do georgiano, o que inclui a forma de identificar e separar os morfemas, foram baseadas e adaptadas a partir do trabalho de Amiridze (2006) e Hillery (2009).
} 
construir alguma coisa' formado pelo afixo causativo -in-, em adição ao sufixo temático $-e b$ - e à vogal pré-radical $-a-.^{3}$

\subsubsection{Classe II}

As características morfológicas usualmente atribuídas a verbos de Classe II são: a formação, assim como verbos de Classe I, do futuro das Séries I e do aoristo das Séries II por meio de um preverbo (ver (2b)); o afixo de concordância - $a$ é usado para marcar, no verbo, o sujeito na terceira pessoa do singular (observe a sentença em (2a)) e o afixo -en para marcar, no verbo, o sujeito na terceira pessoa do plural no futuro e presente; no aoristo das Séries II, o afixo de concordância -en também marca, no verbo, o sujeito na terceira pessoa do plural (HARRIS, 1981; HOLISKY, 1979).

Como mostrado na Tabela 1, diferente de verbos de Classe I, verbos de Classe II têm seu sujeito marcado com o caso nominativo em todas as Séries e não sofrem inversão nas Séries III do Perfeito.

Os exemplos abaixo ilustram um verbo prototípico de Classe II t'qd-eb-a 'quebrar', denotando um evento de um participante e com um sujeito considerado tema, inanimado e não agentivo.

(2a) k'alam-i qoveltvis t'qd-eb-a

caneta-NOM sempre quebrar-ST-3ANOM.SG

A caneta está sempre quebrando.

(2b) k'alam-i ga-t'qd-a ${ }^{4}$ gushin caneta-NOM PV-quebrar-3ANOM.SG.AOR.INDIC ontem A caneta quebrou ontem.

(2c) k'alam-i turme ga-t'exil-a caneta-NOM aparentemente PV-quebrar-3ANOM.SG A caneta aparentemente quebrou.

\footnotetext{
${ }^{3}$ Como se costuma fazer em alguns dicionários da língua georgiana e feito neste trabalho, a forma de citação do verbo é na terceira pessoa do singular no presente, por exemplo, a-shen-eb-s 'ele constrói', sendo traduzida pelo infinitivo em português quando em forma de citação do verbo.

${ }^{4} \mathrm{O}$ morfema - $a$, observado em sentenças no aoristo como (2b), é uma marca de screeve (SM) que varia de acordo com o verbo, pessoa e seguindo, a depender da classe, o padrão 'fraco' ou 'forte', sendo sempre glosado com a pessoa, caso e número a que se refere e com a indicação AOR.INDIC. Esse morfema, como marca de screeve, não é equivalente ao morfema - a presente no último slot em (2a) e (2c) que constitui apenas marca de pessoa.
} 
Verbos de Classe II são tradicionalmente subdivididos em três tipos: verbos passivos prefixais, formados com a vogal pré-radical - $i-$, como, por exemplo, o verbo de sentido passivo na sentença c'eril-i $i$-c'er-eb-a, 'a carta está sendo escrita', derivado do verbo de Classe I c'er-s 'escrever'; verbos sufixais, formados a partir da adição do infixo - $d$ - no slot 5 (ver Tabela 2) junto à raiz. Vários desses verbos são derivados de adjetivos e substantivos, carregando um sentindo incoativo de 'tornar-se alguma coisa', como, por exemplo, c'itl-d-eb-a 'tornar-se vermelho', 'corar'; e verbos sem marca (ou radicais), constituindo formas verbais básicas da classe, i.e., não derivadas, como, por exemplo, k'vd-eb-a 'morrer'.

Os verbos em georgiano tradicionalmente chamados de 'passivos de estado' são também agrupados por alguns na Classe II (cf. HARRIS, 1981) - já outros autores preferem agrupá-los em classe separada (cf. HEWITT, 1995). Esses verbos constituem um grupo restrito de verbos de semântica estativa como, por exemplo, o verbo a-par-i-a 'estar espalhado, coberto', ilustrado a seguir pelo exemplo retirado de Harris (1981):

$\begin{array}{lll}\text { (3) mt'ver-i } \quad \text { a-par-i-a } & \text { iat'ak'-ze } \\ \text { poeira-NOM } & \text { VPR-estar.espalhado-SM-3ANOM.SG } & \text { chão-POSP } \\ \text { A poeira está espalhada no chão. } & \end{array}$

(HARRIS, 1981)

\subsubsection{Classe III}

As propriedades morfológicas levantadas na caracterização de verbos de Classe III podem ser resumidas às seguintes: tanto o futuro quanto o aoristo são formados através da adição da vogal pré-radical $i$ - (observe a sentença no aoristo em (4b) e o futuro do verbo 'jogar' v-i-tamash-eb, 'eu jogarei'); o afixo de concordância -s é utilizado para marcar, no verbo, o sujeito na terceira pessoa do singular (note a sentença no singular em (4a) no tempo presente) e o afixo -en para marcar, no verbo, o sujeito na terceira pessoa do plural no futuro e presente; no aoristo, o afixo de concordância -es marca o sujeito na terceira pessoa do plural (ver sentença (4b)). 
(4a) k'ac-i musha-ob-s qoveldghe

homem-NOM trabalhar-ST-3ANOM.SG todo.dia

O homem trabalha todo dia.

(4b) k'ac-eb-ma i-mushav-es

homem-PL-ERG VPR-trabalhar-3AERG.PL.AOR.INDIC

Os homens trabalharam.

(4c) k'ac-eb-s turme u-mushav-i-a-t

homem-PL-DAT aparentemente VPR-trabalhar-SM-3ANOM-PL.DAT

Os homens aparentemente trabalharam.

Assim como verbos de Classe I, verbos de Classe III sofrem inversão nas Séries III, como pode ser observado na sentença (4c) em que o sujeito é marcado com o caso dativo. Nas Séries II do Aoristo, também da mesma forma que verbos de Classe I, verbos de Classe III têm o sujeito marcado com o caso ergativo.

Ainda que a classificação tradicional considere a Classe III como aquela que engloba verbos intransitivos agentivos, pode-se encontrar, nessa classe, além de verbos de um participante com sujeitos agentivos, também eventos com dois participantes. Dentre as formas verbais básicas de Classe III há aqueles de um participante como $i$-cin$i-s$ 'rir' e quir-i-s 'gritar', e aqueles que podem tomar um segundo participante opcionalmente como tamash-ob-s 'jogar, brincar'. O verbo ilustrado acima musha-ob-s 'trabalhar' exemplifica os verbos denominais da classe. Um terceiro tipo de verbos característicos de Classe III são alguns verbos que expressam eventos durativos tais como dugh-s 'ferver', prial-eb-s 'brilhar', etc.

Holisky (1980) descreve verbos de Classe III como verbos de aspecto inerentemente durativo e que expressam eventos dinâmicos. Para a autora, a base da distinção entre certos verbos intransitivos de Classe II e III é aspectual, enquanto verbos de Classe III como t 'ir- $i-s$ 'chorar' e dugh-s 'ferver' constituem atividades em andamento e, por isso, são considerados atélicos, i.e., sem indicar início ou término da ação, os verbos correspondentes de Classe II sufixais t'ir- $d-e b-a$ 'começar a chorar' e dugh-d-eb-a 'começar a ferver' são télicos incoativos (ARONSON, 1991; HOLISKY, 1981; TUITE, 1998).

\subsubsection{Classe IV}


A verbos de Classe IV são usualmente atribuídas as seguintes características morfológicas: a formação do futuro e do aoristo é feita através da vogal pré-radical $e$-, observe (5b) no futuro, assemelhando-se a verbos de Classe III que formam esses tempos sem preverbos; no futuro, o afixo - $a$ marca sujeitos na terceira pessoa do singular (cf. (5b)) (HARRIS, 1981; HOLISKY, 1979).

Verbos de Classe IV também apresentam a peculiaridade de sofrerem inversão em todas as séries, como pode ser observado pela Tabela 1.
(5a) bich'-eb-s u-qvar-t gogona garoto-PL-DAT VPR-amar-PL menina.NOM Os garotos amam a menina.

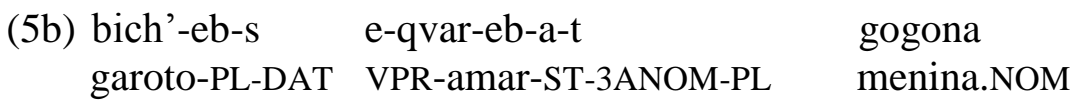
Os garotos amarão a menina ${ }^{5}$
(5c) bich'-eb-s qvar-eb-i-a-t gogona garoto-PL-DAT amar-ST-SM-3ANOM-PL menina.NOM Os garotos aparentemente amaram a menina.

As sentenças em (5) ilustram um verbo prototípico de Classe IV u-qvar-s 'amar'. De modo geral, verbos de Classe IV expressam sensações involuntárias, sintomas, emoções, estados (mentais, físicos), etc. Essa semântica peculiar da classe correlacionase com o caráter de seus sujeitos, considerados típicos experienciadores.

Outros exemplos de verbos característicos da classe são $d z u l-s$ 'odiar', c'qur-i-a 'ter sede' e a-xsov-s 'lembrar-se'. Nessa classe, também são incluídos os chamados verbos de humor, ou desiderativos, que expressam vontade ou desejo de fazer algo, por exemplo, e-mgher-eb-a 'sentir desejo de cantar'.

\footnotetext{
${ }^{5}$ A forma no aoristo do verbo $u$-qvar-s 'amar' não é comum, por isso optou-se por usar, neste caso, um exemplo no tempo futuro.
} 


\section{SISTEMA VERBAL: OUTRAS CARACTERÍSTICAS RELEVANTES}

\subsection{Construções indiretas}

A designação de 'construções indiretas' em georgiano pode ser entendida tradicionalmente, i.e., de um ponto de vista estrutural, como a inversão de certas propriedades atribuídas às construções diretas, i.e., o argumento que é usualmente identificado como sujeito de uma construção direta, por exemplo, o agente de uma sentença transitiva de Classe I - marcado nas Séries I com o caso nominativo e nas Séries II com o caso ergativo e referenciado pelo conjunto de afixos A - é, em uma construção indireta, marcado pelo caso dativo e referenciado pelo conjunto de afixos B (TUITE, 1998).

Uma construção indireta, assim considerada, engloba não somente os casos de inversão nas Séries III, mas também uma série de outras construções em georgiano que seria de valor descrevermos mais atentamente, principalmente atentando para as características em comum entre elas. Dentre essas, há os já referidos verbos de Classe IV, os verbos estativos ou passivos de estado e a tradicionalmente chamada 'construção dativa'. Esse conjunto de construções, como veremos, será importante quando definirmos o que será designado também sob o rótulo de 'construções indiretas', nesse caso, a partir do processo de significação que codificam e de suas similaridades.

\subsubsection{Verbos de Classe IV}

Verbos de Classe IV expressam eventos psíquicos e sensórios, usualmente não volitivos e involuntários, em que o sujeito, um experienciador no caso dativo, não possui controle sobre a ação, sofrendo de alguma forma seus efeitos. Os verbos listados abaixo exemplificam a semântica típica dessa classe (HARRIS, 1981; HEWITT, 1995; TUITE, 1998):

- emoções: $s$-dzul-s 'odiar', u-qvar-s 'amar', mo-s-c'on-s 'gostar', e-shin-i-a 'ter medo', $e$-natr-eb-a 'ter saudades', e-nan-eb-a 'ter arrependimento', rcxv-em-i-a 'ficar embaraçado'. 
- estados (mentais, físicos), sensações involuntárias e sintomas: $a-k$ ' $l-i-a$ 'faltar alguma coisa', ghvidz-av-s 'estar acordado', $s-c$ 'qur-i-a 'ter sede', $h-s h-i-a$ 'ter fome', $a-k v-s$ 'ter alguma coisa', dzin-av-s 'estar adormecido', $u$-nd-a 'querer', s-ch 'ir-s 'precisar', s-t'k 'iv$a$ 'machucar', $s$-civ- $a$ 'estar frio', s-cxel-a 'estar quente', $c h$ 'ir-s 'sofrer de alguma coisa'. - percepção: $e$-sm-i-s 'ouvir, entender', a-xsov-s 'lembrar', a-vic 'q-d-eb-a 'esquecer', $e$ gem-eb-a 'sentir o gosto', e-qnos-eb-a 'sentir o cheiro'.

Grande parte das raízes verbais presente na Classe IV pode ser considerada como básica e não marcada, i.e., essas raízes não são derivadas a partir de outras construções, representando um padrão prototípico na língua, tanto quanto verbos transitivos de Classe I de construção direta (TUITE, 1998).

A qualidade dessas raízes como básicas e não marcadas indicia o forte, e antigo, grau de arraigamento desse tipo de construção indireta na língua, podendo servir, nos termos da Gramática Cognitiva de Langacker, para sancionar novas construções ou permitir que novas construções sejam derivadas a partir dela, o que envolveria tanto a semântica peculiar das construções com esses verbos quanto a estrutura característica de uma construção indireta. No capítulo 5, voltaremos a discutir a canonicidade de construções indiretas com verbos tradicionalmente classificados como de Classe IV, ou seja, a qualidade básica e não marcada atribuída a verbos de Classe IV na língua, no que diz respeito tanto à sua semântica quanto à sua forma. No capítulo 5, ainda serão discutidas as noções de arraigamento e sanção na Gramática Cognitiva.

\subsubsection{Passivos de estado}

Verbos estativos ou 'passivos de estado' são um grupo restrito de verbos que, como o nome indica, denotam estados, e por serem eventos contínuos e imutáveis, sem indicação de início ou término, são inerentemente imperfectivos (HEWITT, 1995).

Os verbos estativos podem ocorrer com um ou dois participantes, o exemplo a seguir ilustra o uso monovalente do verbo $h$ - $k$ 'id-i-a 'estar pendurado, suspenso' retirado de Hewitt (1995): 


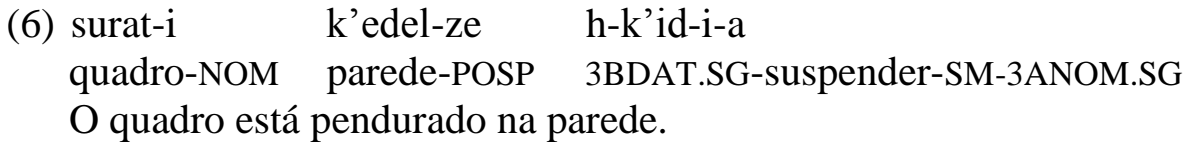

(HEWITT, 1995)

Observe pelo exemplo acima que a marcação de objeto indireto no verbo é obrigatória, mesmo não havendo, no caso de verbos estativos monovalentes, um objeto indireto com o qual a marca do conjunto $\mathrm{B} h$ - concordaria na sentença.

A sentença em (7) exemplifica o uso bivalente do verbo estativo $u$-nt-i-a 'estar aceso'.

(7) mezobel-s cecxl-i u-nt-i-a saxl-shi

vizinho-DAT fogo-NOM VPR-estar.aceso-SM-3ANOM.SG casa-POSP

O vizinho tem fogo aceso em casa (lit. o fogo está aceso na casa do vizinho).

(HILLERY, 2009)

No caso de verbos estativos bivalentes, interessa-nos em particular notar o papel proeminente do objeto indireto nessas construções. Segundo Hewitt (1995) e Hillery (2009), o objeto indireto seria mais salientemente percebido como sujeito, de maneira similar aos outros casos vistos nesta seção, em que o conteúdo informacional da sentença ou mesmo seu foco parece se referir ou ser feito mais ao argumento dativo do que ao argumento nominativo. Por essa razão, Hillery (2009) argumenta ser preferível traduzir a sentença acima como 'o vizinho tem fogo aceso em casa', dando foco ao argumento dativo, do que a tradução mais literal entre parênteses.

\subsubsection{Construção dativa}

Aronson (1999) chama de verbos de construção dativa usualmente verbos que apresentam um argumento dativo animado em conjunto com um argumento nominativo inanimado. Tschenkeli (1958a), em sua gramática e dicionário de referência, designa esse tipo de construção de objektive Reihe - implicando que, por consequência, enquanto os afixos do conjunto B são usados para todas as pessoas (concordando com o argumento dativo animado), apenas as marcas de terceira pessoa do conjunto de afixos A seriam 
normalmente usadas (concordando com o argumento inanimado nominativo) (TUITE, 1998).

Segundo Tuite (1998), grande parte dos verbos listados por Tschenkeli são verbos de Classe II e apenas uma pequena percentagem são verbos de Classe I.

A sentença em (8) exemplifica um verbo de Classe II em uma construção dativa, apresentando um argumento dativo animado e um argumento nominativo inanimado. Observe que, assim como no caso de verbos de Classe IV e estativos, a tendência é interpretar o nominal no dativo como sujeito:

(8) mdzghol-s benzin-i gaza-ze da-u-mtavr-d-a motorista-DAT gasolina-NOM caminho-POSP PV-VPR-acabar-PI-3ANOM.SG.AOR.INDIC O motorista ficou sem gasolina no caminho.

(HILLERY, 2009)

Dentre os verbos de Classe I, Tuite (1998) lista exemplos como $u$-cxun-eb-s com um argumento possuidor, significando 'alguma coisa (e.g. sol) queima alguma coisa de alguém (e.g. parte do corpo)' em que o primeiro argumento é o nominal nominativo inanimado e o último, o nominal dativo animado, nesse caso, o possuidor. E também exemplos como ga-a-p'irkush-eb-s com um argumento experienciador, significando 'alguma coisa coloca alguém de mau humor', em que o último argumento é o nominal dativo animado.

\subsection{Concordância de número de terceira pessoa}

Em georgiano, usualmente apenas nominais animados acionam marcas de concordância de plural no verbo na posição de sujeito. Nominais plurais inanimados de terceira pessoa em - eb não acionam marca de plural no verbo que, dessa forma, permanece na terceira pessoa do singular. Da mesma forma, objetos diretos e indiretos na terceira pessoa também não acionam concordância de plural no verbo (ARONSON, 1999). No exemplo a seguir, retirado de Aronson (1982a), o sujeito nominativo plural, denotando uma entidade inanimada, não aciona pluralidade no verbo: 
(9) gakvetil-eb-i male mo-mzad-d-eb-a lição-PL-NOM logo PV-estar.pronta-PI-ST-3ANOM.SG Logo as lições estarão prontas.

(ARONSON, 1982a)

Com verbos de Classe IV, no entanto, e demais grupos de verbos discutidos na seção anterior, a tendência é haver concordância de plural com o objeto indireto, especialmente quando este é animado.

Nos casos de concordância com a terceira pessoa em particular, é interessante notar a diferença referente à marcação de concordância de sintagmas plurais em paradigmas sem inversão e paradigmas com inversão (cf. GUREVICH, 2004). A Tabela 6 mostra o paradigma de concordância verbal com o objeto de terceira pessoa das Séries I do presente, usando como exemplo o verbo xedva 'ver'.

\begin{tabular}{|c|c|}
\hline \multirow{2}{*}{ Sujeito } & Objeto \\
\cline { 2 - 2 } & $3^{\mathrm{a}}$ pessoa \\
\hline 1SG & v-xed-av \\
\hline 1PL & v-xed-av-t \\
\hline 2SG & xed-av \\
\hline 2PL & xed-av-t \\
\hline 3SG & xed-av-s \\
\hline 3PL & xed-av-en \\
\hline
\end{tabular}

Tabela 6: Concordância com objeto de terceira pessoa - Séries I do presente (padrão normal).

Diferente da concordância com o sujeito na terceira pessoa em que há uma marca explícita indicando a pessoa e número, a concordância com o objeto na terceira pessoa não possui uma marca explícita, não sendo possível distinguir uma forma singular e uma plural. Observe agora a Tabela 7, mostrando o paradigma de inversão do verbo xedva (radical nax-).

No geral, as marcas de concordância em paradigmas de inversão são como um espelho do paradigma 'normal' de concordância, i.e., os afixos do conjunto A passam a concordar com o objeto, e os afixos do conjunto B com o sujeito no dativo. A exceção a esse espelhamento é a concordância com a terceira pessoa. 


\begin{tabular}{|c|c|c|}
\hline \multirow{2}{*}{ Objeto } & \multicolumn{2}{|c|}{ Sujeito } \\
\hline & $3^{a}$ pessoa sg. & $3^{\mathrm{a}}$ pessoa pl. \\
\hline $1 \mathrm{SG}$ & \multicolumn{2}{|c|}{ v-u-nax-av-var } \\
\hline 1PL & \multicolumn{2}{|c|}{ v-u-nax-av-var-t } \\
\hline $2 \mathrm{SG}$ & \multicolumn{2}{|c|}{ u-nax-av-xar } \\
\hline $2 \mathrm{PL}$ & \multicolumn{2}{|c|}{ u-nax-av-xar-t } \\
\hline 3 & u-nax-av-s & u-nax-av-t \\
\hline
\end{tabular}

Tabela 7: Concordância com o sujeito de terceira pessoa (objeto indireto no dativo) - Séries III do perfeito (padrão de inversão).

A concordância com o sujeito de terceira pessoa em paradigmas de inversão não distingue formas singulares de formais plurais, exceto quando o objeto é de terceira pessoa, como pode ser observado na Tabela 7.

Essa preferência no georgiano moderno de verbos de Classe IV e demais verbos indiretos por concordar com o objeto indireto pode ser observada através das sentenças a seguir, retiradas de Tuite (1998):

(10a) mat da-e-drik'-a-t mat-i p'ir-eb-i mic'-isa-k'en. 3PL-DAT PV-VPR-voltar-3ANOM-PL seu-NOM rosto-PL-NOM chão-GEN-em.direção "Eles voltaram suas faces em direção ao chão."

(10b) tu g-i-q'var-d-e(s)-t tkven tkven-i moq'vare-eb-i se 2BDAT-VPR-amar-PI-3ANOM-PL 2PL.DAT seu.PL-NOM amante-PL-NOM "Se vocês amarem aqueles que os amam..."

(TUITE, 1998)

Em (10a), a marca de plural - $t$ concorda com o argumento dativo mat 'eles', em (10b), a marca de segunda pessoa plural $g-t$ concorda com o nominal no dativo tkven 'vocês'.

Segundo Tuite (1998), no entanto, essa tendência a concordar com o objeto indireto plural nem sempre vigorou na língua. No georgiano antigo, as sentenças acima corresponderiam a:

(11a) mat da-X-e-drik'-nes p'ir-n-i mat-n-i kweq'n-ad 3PL.DAT PV-3BDAT-VPR-voltar-3ANOM.PL rosto-PL-NOM seu-PL-NOM terra-AD "Eles voltaram suas faces em direção ao chão." [Luke 24:5 (Xanm.; c. 500 AD)]

(11b) uk'wetu g-i-q'war-d-en tkwen moq'ware-n-i tkwen-n-i se 2BDAT-VPR-amar-PI-3ANOM.PL 2PL.DAT amante-PL-NOM seu-PL-NOM "Se vocês amarem aqueles que os amam..." [Luke 6:32 (Xanm.)]

(TUITE, 1998) 
Em ambos os exemplos, retirados de Tuite (1998), a concordância se dá com o argumento nominativo, o inverso da situação observada em (10). Em (11a), -nes concorda

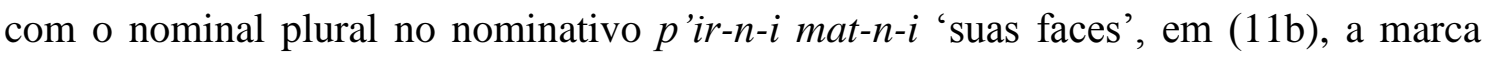
plural -en concorda igualmente com o argumento nominativo no plural moq'ware-n-i tkwen- $n-i$ 'seus amantes'.

Para Tuite (1998), essa mudança se deu em razão de um deslocamento de foco do sujeito morfológico (nominais marcados pelo caso nominativo e referenciados pelos afixos do conjunto A de concordância) no georgiano antigo para o sujeito semântico (nominais marcados pelo caso dativo e referenciados pelos afixos do conjunto B de concordância) no georgiano moderno.

Essa tendência em concordar com o objeto indireto também pode ser atestada em algumas das classes marginais de verbos aqui estudadas e que serão discutidas mais detalhadamente nas próximas seções. Por enquanto, é suficiente observar a concordância desses grupos de verbos com o objeto indireto. Os exemplos a seguir, portanto, mostram verbos de Classe II aparecendo no que foi chamado aqui de construção indireta:

(12a) nino-s bavshv-i da-e-k'arg-a Nino-DAT criança-NOM PV-VPR-perder-3ANOM.SG.AOR.INDIC Nino perdeu a criança.

(12b) nino-s bavshv-eb-i da-e-k'arg-a Nino-DAT criança-PL-NOM PV-VPR-perder-3ANOM.AOR.INDIC Nino perdeu as crianças.

(12c) gogon-eb-s bavshv-i da-e-k'arg-a-t menina-PL-DAT criança-NOM PV-VPR-perder-3ANOM.AOR.INDIC-PL As meninas perderam a criança.

(12d) gogon-eb-s bavshv-eb-i da-e-k'arg-a-t menina-PL-DAT criança-PL-NOM PV-VPR-perder-3ANOM.AOR.INDIC-PL As meninas perderam as crianças.

(ASATIANI, 1998)

Nos exemplos, mesmo quando há um argumento nominativo animado no plural, a concordância é com o objeto indireto, sendo mais visível nos exemplos (12c) e (12d) em que o nominal no dativo está no plural e aciona o afixo de plural - $t$.

Verbos de Classe I que ocorrem nesse tipo de construção indireta apresentam concordância com o objeto indireto particularmente quando este é animado e o argumento 
nominativo inanimado, formação usual para esse grupo de verbos como será discutido adiante. Aronson (1999) fornece os exemplos a seguir:

(13a) es teoria / es teori-eb-i mas aint'eres-eb-s esse teoria.NOM esse teoria-PL-NOM 3SG.DAT interessar-ST-3ANOM.SG Essa teoria/Essas teorias interessam-no.

(13b) es teoria / es teori-eb-i mat aint'eres-eb-t esse teoria.NOM esse teoria-PL-NOM 3PL.DAT interessar-ST-PL Essa teoria/Essas teorias interessam-nos.

(13c) mat ra ac'ux-eb-t

3PL.DAT que incomodar-ST-PL

O que os incomoda?

(ARONSON, 1999)

De acordo com o autor, quando, no entanto, o foco recai no argumento nominativo, indicando que o foco de interesse está nele e não no objeto, a concordância acontece com o nominal no nominativo:

(14a) k'arg-i moxseneba msmenel-eb-s aint'eres-eb-s bom-NOM fala.NOM ouvinte-PL-DAT interessar-ST-3ANOM.SG Uma boa fala interessa os ouvintes.

(ARONSON, 1999)

Inicialmente, é possível perceber que os padrões de concordância, principalmente se vistos sob a perspectiva da terceira pessoa, envolvem uma série de interações complexas entre animacidade, foco, saliência etc., como será discutido no capítulo 5.

\subsection{Vogais pré-radicais}

Como o próprio nome já indica, as vogais pré-radicais - quando presentes -, ocupam, invariavelmente, o slot que imediatamente precede a raiz verbal, não sendo possível aparecerem duas vogais pré-radicais concomitantemente. 
As vogais pré-radicais são conhecidas na literatura linguística georgiana como sendo responsáveis por uma variedade de funções que só podem ser identificadas dentro do contexto morfossintático em que se encontram (cf. GUREVICH, 2006), pois interagem diretamente com propriedades distintas, como voz, estrutura argumental dos verbos, tempo/modo/aspecto, concordância verbal etc.

E como veremos, essas diferentes funções pelas quais a vogal pré-radical é responsável nem sempre têm uma relação entre si, seja sincrônica ou diacrônica, que pode ser claramente estabelecida ou definida, sendo ainda motivo de discussão (cf. GUREVICH, 2006; TUITE, 2007). Ainda assim, dentro da literatura, algumas relações são comumente traçadas entre suas diferentes funções e propriedades, o que nos sugere que em algum ponto de sua história houve o que se poderia chamar de uma extensão de alguns dos seus usos mais 'primitivos' a outros.

Uma das funções centrais que é atribuída às vogais pré-radicais é a de versão verbal, à qual tentaremos nos ater no momento, passando depois às suas demais funções.

A versão verbal é conhecida em georgiano por incorporar à estrutura do verbo propriedades argumentais e semânticas, e segundo Gurevich (2006, p. 8), passa a indicar que aquele constituinte adicionado é afetado pela ação do verbo, atribuindo-lhe certo grau de saliência. Dessa forma, as versões verbais diferem entre si na medida em que marcam diferentes propriedades relacionadas ao verbo, e estas são:

- Versão objetiva - marcada pela vogal pré-radical - $i$ - quando o objeto indireto beneficiário da ação está na primeira ou segunda pessoa, e pela vogal pré-radical - $u$ quando o objeto estiver na terceira pessoa.

- Versão subjetiva - marcada pela vogal pré-radical - $i$ - quando o sujeito for o participante afetado ou o beneficiário da ação exercida pelo verbo.

- Versão locativa - marcada pela vogal pré-radical - $a$ - quando houver um objeto indireto locativo, indicando, por exemplo, alguma relação espacial em relação à ação do verbo.

- Versão neutra (ou zero) - marcada pela vogal pré-radical - $a$ - quando não houver nenhuma propriedade argumental ou semântica adicional ligada ao verbo.

As funções descritas acima das versões verbais são usadas em verbos de Classe I e verbos de Classe III. É importante notar que em relação à maior parte dos usos descritos acima, uma forma alternativa pode ser usada ao invés da versão verbal, e esta se refere ao uso de um sintagma nominal posposicionado, isto é, há a possibilidade de usarmos uma posposição junto ao nome para expressar as relações temáticas associadas ao uso das 
versões. No entanto, a diferença sintática fundamental entre as duas possibilidades é que a versão verbal adiciona propriedades argumentais ao verbo, gerando concordância, enquanto que um sintagma posposicional não faz parte da estrutura argumental do verbo, não havendo concordância (HARRIS, 1981, p. 88).

Verbos de Classe II e IV, como veremos, por possuírem uma morfologia distinta, marcam essas relações de forma um tanto peculiar, porém, relacionada.

Em verbos de Classe IV, verbos 'psíquicos', e verbos nas Séries III que apresentam inversão, as vogais pré-radicais são usadas obrigatoriamente para indicar o sujeito lógico no dativo, i.e., $-i$ - para primeira ou segunda pessoa e $-u$ - para terceira pessoa. No tempo mais-que-perfeito, a vogal pré-radical - $e$ - é usada para todas as pessoas (HEWITT, 1995).

Embora, provavelmente, esse uso das vogais pré-radicais esteja relacionado historicamente ao uso da versão objetiva em verbos transitivos de Classe I e verbos de Classe II, sincronicamente, acaba por tomar diferentes funções, pois seu uso é obrigatório por razões diretamente ligadas à morfologia e sintaxe de verbos de Classe IV juntamente com morfologia de tempo/modo/aspecto em outras classes. Dessa forma, é igualmente requerida para marcar as Séries III tanto em verbos de Classe I quanto em verbos de Classe III que sofrem inversão, como pode ser observado na sentença com um verbo de Classe I no perfeito das Séries III 'mas saxli a-u-sheneb-ia' - 'Ele (aparentemente) construiu a casa' -, em que a vogal pré-radical - $u$ - concorda com o nominal no dativo de terceira pessoa mas, 'ele', sendo obrigatória.

Em verbos de Classe II, formados pela vogal pré-radical - $i$ - mais o sufixo temático -eb-, a vogal pré-radical - $e$ - marca a presença de um argumento extra ou participante afetado, podendo indicar quaisquer propriedades temáticas listadas acima pelo uso das outras vogais pré-radicais (HEWITT, 1995, p. 204). Dessa forma, a vogal pré-radical -emarca o que seria um objeto indireto no dativo em verbos intransitivos (cf. HARRIS, 1981; HEWITT, 1995).

Em adição a esses usos das vogais pré-radicais como versão verbal, as vogais préradicais $-i$ - e - $e$ - são também responsáveis pela marcação de tempo/modo/aspecto de verbos de Classe III e verbos de Classe IV. Possuem, nesse caso, uma função particularmente 'gramatical', já que servem para formar o futuro e outros tempos verbais juntamente com o sufixo - $e b$ - - compare o verbo de Classe III no presente das Séries I vtamash-ob, 'eu jogo', com o mesmo verbo no futuro v-i-tamash-eb, 'eu jogarei'. 
Por considerarem verbos de Classe III (denotam uma atividade) e verbos de Classe IV (verbos psíquicos) como atélicos, é provável que houvesse uma restrição nesses verbos quanto ao uso dos preverbos que denotam aspecto perfectivo e são usados na formação do futuro e outros tempos verbais em verbos transitivos de Classe I e verbos de Classe II. Dessa forma, talvez por extensão, os verbos de Classe III e IV tenham passado a formar o futuro com a vogal pré-radical mais o sufixo temático -eb-, forma esta idêntica à formação de verbos de Classe II (GUREVICH, 2006; TUITE, 2007, p. 10).

O que é interessante notar é que os verbos de Classe IV formam o futuro e outros tempos com a vogal pré-radical - $e$ - juntamente com o sufixo temático - eb-, enquanto os verbos de Classe III usam a vogal pré-radical - $i-$, ou seja, na presença do sujeito lógico no dativo em verbos psíquicos, a vogal pré-radical - $e$ - é empregada ao invés da vogal préradical $-i$-, lembrando-nos de seu uso similar ao emprego da vogal pré-radical - $e$ - nos verbos de Classe II.

Outra função atribuída à vogal pré-radical - $i$ - é de passividade, sendo responsável pela formação de verbos passivos prefixais de Classe II, a passiva sintética como chamada por Harris (1981). Dessa forma, a vogal pré-radical - $i$ - derivaria tanto verbos passivos de Classe II quanto verbos inativos de Classe II. Nesse caso, se pensarmos em termos de argumentos licenciados pelas vogais pré-radicais em verbos de Classe II, a vogal préradical - $i$ - marcaria a ausência de um argumento extra ou objeto indireto, enquanto que a vogal pré-radical - $e$ - marcaria a presença de um argumento extra ou objeto indireto (GUREVICH, 2006, p. 8).

Por fim, a vogal pré-radical - $i$ - também é usada em algumas formações reflexivas (cf. AMIRIDZE, 2006), função associada estruturalmente à versão subjetiva juntamente com a passividade (cf. CYRINO, 2011; TUITE, 2007).

Exposto isso, é possível concluir esta seção com algumas considerações que serão importantes adiante:

- As vogais pré-radicais provocam mudanças argumentais nos verbos, acrescentando ao verbo propriedades argumentais e temáticas à sua estrutura;

- As vogais pré-radicais, além de poderem licenciar um argumento a mais, são responsáveis por tornar um sintagma nominal um argumento sintático do verbo.

Mesmo que as duas características acima sejam mais aplicáveis à função de versão verbal das vogais pré-radicais, não são completamente estranhas às outras funções 
atribuídas às vogais pré-radicais, sendo relacionadas a mudanças argumentais e à marcação de argumentos, a saber:

- Assim como as vogais pré-radicais podem tornar um SN um argumento verbal, também poderiam indicar o apagamento de argumentos da estrutura sintática do verbo, processos de detransitivização em verbos passivos e inativos de Classe II são um exemplo;

- Acabam por indicar ou marcar, em outras diferentes funções, o objeto indireto no dativo, como nos verbos de Classe IV e em verbos nas Séries III que apresentam inversão, e, similarmente, no futuro e outros tempos verbais de Classe IV, no caso da vogal pré-radical $-e-$.

E por fim, sobre as vogais pré-radicais e suas diferentes funções gramaticais, algumas questões a se considerar:

- Por apresentarem diversas funções, os usos das vogais pré-radicais acabam por depender essencialmente de contextos e construções morfossintáticas maiores. Não sendo possível defini-las ou explicá-las isoladamente ou apenas levando em consideração um número $X$ de características, sejam sintáticas, morfológicas ou semânticas que poderiam se aplicar a um uso, porém, não necessariamente a usos, a princípio, similares;

- Ainda que, sincronicamente, essas funções e construções acabem por ter pouca relação - justamente por aparecerem em diferentes ambientes morfossintáticos -, possivelmente esses usos, e outros, da vogal pré-radical formam, diacronicamente, uma cadeia coerente de relações em comum no que diz respeito à sua origem e formação. 


\section{SISTEMA VERBAL: GRUPOS MARGINAIS DE VERBOS}

Dessas tendências maiores até agora vistas, outras menores ou mais marginais parecem se formar - ou às vezes restar -, como a desprender-se, carregando consigo propriedades daquela construção e podendo, concomitantemente, tomar a forma de outras. O que acaba por formar construções, por vezes, completamente diferentes ou independentes, ou, por outras, formando um continuum.

A esses agrupamentos menores ou marginais costumam dar o nome de 'exceções'. Como consequência em alguns casos, pouca atenção é dada a esses grupos de verbos, como salienta Tuite (2009), ele mesmo tendo devotado diversos artigos a essas classes de verbos menores ou menos produtivas (cf. TUITE, 2002; 2007; 2009).

Assim como em relação às classes verbais maiores como mencionamos, grupos menores de verbos são suficientemente consistentes para que também revelem tendências bastante específicas presentes na língua, em outras palavras, destacam-se por gerar mudanças argumentais na estrutura verbal, codificando ou refletindo, consequentemente, diferentes processos de significação.

Desse modo, como começamos a expor anteriormente, classes verbais marginais são assim chamadas, não somente por representarem um número menor, mas principalmente por se desviarem do padrão dominante representado por classes maiores de verbos nas quais acabam tradicionalmente por ser inseridas, estando no que Tuite (2007) chama de 'limiar', diacrônica e sincronicamente, entre construções morfossintáticas maiores.

Essas construções menores e os diferentes mapeamentos em sua estrutura mostram processos de significação distintos, isto é, há tendências bastante específicas sendo codificadas na língua através da mudança estrutural nessas classes de verbos marginais tanto quanto ocorre em classes mais centrais ou proeminentes.

\subsection{Verbos direto-indiretos (labiles)}

\subsubsection{Verbos de Classe II e verbos de Classe I}


Como já notado, verbos de Classe II, caracteristicamente, formam o futuro das Séries I e do aoristo das Séries II por meio de um preverbo e têm seu sujeito marcado com o caso nominativo em todas as Séries, não sofrendo inversão nas Séries III do Perfeito. Semanticamente, atribui-se a verbos de Classe II uma semântica passiva, sinalizada em particular pela presença da vogal pré-radical - $i$ - (ver seção 3.3 sobre as vogais pré-radicais em georgiano). Verbos de Classe II com a vogal pré-radical - $i$ - tomam apenas um argumento e são chamados, tradicionalmente, de absolutos. Quando, no entanto, há a adição de um argumento extra à grade argumental, usualmente um objeto indireto, alterna-se a vogal pré-radical - $i$ - para a vogal pré-radical - $e$ - que, portanto, passa a sinalizar a presença de um argumento extra na grade argumental do verbo. Verbos com a vogal pré-radical - $e$ - de Classe II são chamados, tradicionalmente, de verbos relativos.

Os verbos exemplificados a seguir (ver exemplos de (15) a (21) abaixo) são, formalmente, verbos de Classe II. Os exemplos de (15) a (18) são verbos relativos de Classe II, isto é, verbos com a vogal pré-radical -e-, classificados como Relatives Passiv (RP) por Tschenkeli em seu dicionário georgiano-alemão (1965-74), doravante (GDW). Os verbos de Classe II em (20) e (21) não apresentam a vogal pré-radical -e-; em (20), são verbos relativos que apresentam as marcas de concordância com o objeto indireto da série em - $h$ - e em (21) são verbos relativos de Classe II com as marcas de concordância com o objeto indireto da série em - $u$ - (ver seção 2.2.2 sobre as marcas de concordância). Os verbos mencionados acima são caracterizados por Tschenkeli, em seu dicionário, por apresentarem Objektive Reihe (OR), isto é, são classificados como também apresentando o que costumam chamar de 'construção dativa' (ver seção 3.1.3), i.e., podem também aparecer com um argumento dativo animado e um argumento nominativo inanimado.

Em (19), é exemplificado o contraste entre um verbo direto-indireto de Classe II, sendo usado na construção indireta em (19a) e um verbo direto de Classe I em (19a'). 
(15) Verbos direto-indiretos de Classe II com VPR -e-. ${ }^{6}$

a. kurd-i ga-e-p'ar-a p'oliciel-eb-s ladrão-NOM PV-VPR-escapar-3ANOM.AOR.INDIC polícia-PL-DAT

a'. p'oliciel-eb-s ga-e-p'ar-a-t kurd-i polícia-PL-DAT PV-VPR-escapar-3ANOM.AOR.INDIC-PL.DAT ladrão-NOM

O ladrão escapou da polícia.

b. mepe e-chven-eb-a xalx-s

rei.NOM VPR-aparecer-ST-3ANOM.SG pessoas-DAT

$\mathrm{O}$ rei se mostra para as pessoas.

b'. deda-s e-chven-eb-a shvil-i sizmar-shi mãe-DAT VPR- aparecer-ST-3ANOM.SG criança-NOM sonho-POSP A criança aparece para a mãe no sonho. [A mãe vê a criança aparecendo.]

c. gak'vetil-i e-c'q'-eb-a moc'ape-eb-s xval rva lição-NOM VPR-começar-ST-3ANOM.SG estudante-PL-DAT amanhã oito saat-ze hora-POSP

c'. moc'ape-eb-s e-c'q'-eb-a-t gak'vetil-i xval rva estudante-PL-DAT VPR-começar-ST-3ANOM-PL.DAT lição-NOM amanhã oito saat-ze hora-POSP

A lição começa para os estudantes amanhã às oito horas.

[Adaptados de Tschenkeli (1958a)]

(16) Verbos direto-indiretos de Classe II com VPR -e-.

a. ded-eb-s e-chven-eb-i-an tavianti bavshv-eb-i mãe-PL-DAT VPR-aparecer-ST-SM-3ANOM.PL suas criança-PL-NOM As crianças apareceram diante de suas mães.

a'. ded-eb-s e-chven-eb-a-t tavianti bavshv-eb-i mãe-PL-DAT VPR-aparecer-ST-3ANOM-PL.DAT suas criança-PL-NOM As crianças apareceram para suas mães (em sonho).

\footnotetext{
${ }^{6}$ Como os exemplos deste capítulo serão retomados com bastante frequência no capítulo 5, optou-se por organizá-los ou agrupá-los em conjuntos para facilitar sua referência e retomada posterior. Os exemplos também podem ser visualizados no apêndice.
} 
b. damsheul dzaghl-eb-s mgl-eb-i e-c-nen

famintos cão-PL-DAT lobo-PL-NOM VPR-cair-3ANOM.PL

Os lobos caíram sobre os cães famintos.

b'. damsheul dzaghl-eb-s sun-i e-c-a-t

famintos cão-PL-DAT odor-NOM VPR-cair-3ANOM-PL

Os cães famintos sentiram o odor.

[Adaptados de Tuite (1998)]

(17) Verbos direto-indiretos de Classe II com VPR -e-.

a. bavshv-eb-i e-mal-eb-i-an ertmanet-s

criança-PL-NOM VPR-esconder-ST-SM-3ANOM.PL um.ao.outro-DAT

a'. bavshv-eb-s e-mal-eb-a-t ertmanet-i

criança-PL-DAT VPR-esconder-ST-3ANOM-PL.DAT um.ao.outro-NOM

As crianças se escondem umas das outras.

b. bavshv-eb-i da-e-k'arg-nen ertmanet-s

criança-PL-NOM PV-VPR-perder-3ANOM.PL um.ao.outro-DAT

b'. bavshv-eb-s da-e-k'arg-a-t ertmanet-i

criança-PL-DAT PV-VPR-perder-3ANOM-PL.DAT um.ao.outro-NOM

As crianças perderam-se umas das outras.

[Adaptados de Tuite (1998)]

(18) Verbos direto-indiretos de Classe II com VPR -e-.

a. bavshv-eb-i e-mal-eb-i-an ded-eb-s

criança-PL-NOM VPR-esconder-ST-SM-3ANOM.PL mãe-DAT

As crianças estão se escondendo de suas mães.

a'. bavshv-eb-s e-mal-eb-a-t ded-eb-i

criança-PL-DAT VPR-esconder-ST-3ANOM-PL.DAT mães-NOM

As crianças estão se escondendo de suas mães (no entanto, não o fazem de propósito). 
(19) Contraste entre verbo direto de Classe I e verbo de Classe II direto-indireto.

a. am sak'itxis axsnisas bevri dro da-m-e-k'arg-a esse questão.GEN explicação muito tempo PV-1BDAT.SG-VPR-perder-3ANOM.AOR.INDIC Eu perdi muito tempo durante a explicação dessa questão (eu não tinha a intenção).

a'. bevri dro da-v-k'arg-e muito tempo PV-1AERG.SG-perder-AOR.INDIC Eu perdi muito tempo.

[Adaptados de Asatiani (1998)]

(20) Verbos de Classe II direto-indiretos sem vogal pré-radical -e-.
a. kal-eb-i she-xvd-eb-i-an kmr-eb-s mulher-PL-NOM PV-encontrar-ST-SM-3ANOM.PL marido-PL-DAT As mulheres encontrarão os maridos.
a'. kal-eb-i she-xvd-eb-a-t kmr-eb-s mulher-PL-NOM PV-encontrar-ST-3ANOM.AOR.INDIC-PL.DAT marido-PL-DAT Os maridos encontrarão as mulheres (por acaso).

[Adaptados de Tuite (1998)]

(21) Verbos direto-indiretos de Classe II com a vogal pré-radical - $u$-.
a. es saxl-i da-u-jd-a chem-s mshobl-eb-s esta casa-NOM PV-VPR-custar-3ANOM.SG.AOR.INDIC meu-DAT pais-PL-DAT bevri pul-i muito dinheiro-NOM
a'. chem-s mshobl-eb-s da-u-jd-a-t es saxli meu-DAT pais-PL-DAT PV-VPR-custar-3ANOM.AOR.INDIC-PL esta casa-NOM bevri pul-i muito dinheiro-NOM

Esta casa custou muito dinheiro aos meus pais.

[Adaptados de Tschenkeli (1958a)]

De forma similar a verbos de Classe II, verbos de Classe I formam o futuro das Séries I e do aoristo das Séries II por meio de um preverbo, diferentemente da Classe II, no entanto, têm seu sujeito marcado com o caso nominativo nas Séries I, nas Séries II 
com o caso ergativo e sofrem inversão nas Séries III do Perfeito. Usualmente são verbos diretos de semântica ativa, com sujeitos agentivos. Os verbos exemplificados em (22) e na Tabela 8 são, formalmente, verbos de Classe I, no entanto, como será discutido logo a frente, se distinguem em importantes aspectos do restante da classe, principalmente no que se refere à sua semântica.

De forma similar ao grupo de verbos de Classe II citado há pouco, os verbos de Classe I abaixo - classificados, por conseguinte, no GDW de Tschenkeli como $T^{1}$ (Transitiv in Neutraler Version), i.e., verbos de Classe I com vogal pré-radical - $a$-, a versão neutra -, são caracterizados no mesmo dicionário por 'Objektive Reihe', i.e., ocorrem na construção dativa.

A Tabela 8 retirada de Tuite (1998) lista alguns verbos pertencentes a essa pequena classe de verbos de Classe I direto-indiretos. A seguir, são exemplificadas algumas sentenças que mostram o contraste entre esses verbos ocorrendo em construções diretas e indiretas.

\begin{tabular}{|c|c|}
\hline $\begin{array}{c}\text { Forma do futuro na } \\
3^{a} \text { pessoa sg. }\end{array}$ & Significado \\
\hline da-a-int'eres-eb-s & interessar alguém \\
\hline ga-a-k'virv-eb-s & surpreender alguém \\
\hline da-a-mt'vrev-s & cansar alguém \\
\hline da-a-mdzim-eb-s & sobrecarregar alguém \\
\hline da-a-naghvl-eb-s & perturbar alguém \\
\hline ga-a-oc-eb-s & espantar alguém \\
\hline she-a-c'ux-eb-s & incomodar alguém \\
\hline ga-a-xar-eb-s & alegrar alguém \\
\hline
\end{tabular}

Tabela 8: Verbos lábeis (direto-indiretos) de Classe I (TUITE, 1998, p.37)

(22) Verbos direto-indiretos de Classe I

a. umcros-eb-s upros-eb-i a-c'ux-eb-d-nen mais.jovens-PL-DAT mais.velhos-PL-NOM VPR-incomodar-ST-SA-3ANOM.PL Os mais velhos estavam incomodando os mais jovens.

a'. umcros-eb-s ... ar a-c'ux-eb-d-a-t es mais.jovens-PL-DAT não VPR-incomodar-ST-SA-3ANOM-PL.DAT essa morchileba submissão.NOM Os mais jovens não se incomodaram em se submeter (à regra) [lit. aos mais jovens não incomodou se submeter à regra]. 
b. masc'avlebel-i mosc'avle-s a-xasiat-eb-s professor-NOM estudante-DAT VPR-caracterizar-ST-3A NOM.SG $\mathrm{O}$ professor caracteriza o estudante.

b'. am mosc'avle-s k'argi michveva a-xasiat-eb-s esse estudante-DAT bom hábito.NOM VPR-caracterizar-ST-3ANOM.SG Esse estudante é caracterizado por bons hábitos.

c. amxanag-eb-i a-xar-eb-en ertmanet-s colega-PL-NOM VPR-fazer-ST-3ANOM.PL um.ao.outro-DAT Os amigos fazem uns aos outros felizes.

c'. amxanag-eb-s a-xar-eb-t ertmanet-is ambeb-i colega-PL-DAT VPR-fazer-ST-PL.DAT um.ao.outro-GEN notícias-NOM Os amigos estão felizes com as notícias um do outro (lit. "as notícias um do outro fazem os amigos felizes").

d. es gogo-eb-i ertmanet-s a-int'eres-eb-en zghap'r-eb-it essa garota-PL-NOM um.ao.outro-DAT VPR-interessar-ST-3ANOM.PL conto-PL-INST Essas garotas estão interessando uma a outra em contos.

d'. am gogo-eb-s ertmanet-i a-int'eres-eb-t essa garota-PL-DAT um.ao.outro-NOM VPR-interessar-ST-PL.DAT Essas garotas estão interessadas uma na outra.

[Adaptados de Tuite (1998)]

(23) Verbos direto-indiretos de Classe I

a. mariam-i a-cxel-eb-s c'q'al-s Maria-NOM VPR-esquentar-ST-3ANOM.SG água-DAT Maria está esquentando a água.

a'. avadmq'op-s a-cxel-eb-s paciente-DAT VPR-esquentar-ST-3ANOM.SG O paciente está com febre.

[Adaptados de Tschenkeli (1958)]

O que difere esses dois grupos de verbos exemplificados nesta seção de outros verbos canônicos de Classe II e de Classe I é que eles podem alternar entre construções diretas e indiretas, i.e., ocorrem tanto em uma quanto em outra, tendo significados distintos dependendo da construção na qual aparecem, se direta ou indireta. 
Por essa razão, Tuite (1998) chama esses verbos de lábeis (labiles) - termo cunhado por Chikobava (1967) -, designando a alternância da mesma forma verbal entre construção direta e indireta.

E como Tuite (1998) nota, essa liberdade de esses verbos em alternar entre uma construção e outra não é particularmente comum na língua, já que a maioria dos verbos em georgiano ou é considerada direta ou indireta, por ocorrer, justamente, ou em construções diretas ou indiretas.

$\mathrm{O}$ fato de os verbos direto-indiretos, como chamados aqui, poderem ocorrer nas duas construções sem alterar sua forma resulta em certa ambiguidade quanto à sua distinção e divergência quanto aos parâmetros usados para distinguir uma forma da outra (observe nos exemplos em (15), (16), (17), (18), (20), (21), (22) e (23), em que as sentenças em contraste nos pares não diferem em forma, sendo formalmente iguais).

O diagnóstico, portanto, para se diferenciar as duas formas nem sempre é baseado em parâmetros formais absolutos, podendo haver certa divergência a depender da análise proposta (para outras análises desses verbos, em particular dos verbos de Classe II diretoindiretos, ver Aronson (1984) e Hewitt (1987)). Em geral, os parâmetros usados, além, naturalmente, do contexto, são concordância, percepção do nominal dativo (o objeto indireto) como sendo o sujeito e ordem de palavras.

O primeiro parâmetro, portanto, que serviria para desambiguar as formas e que indicaria se o verbo está sendo usado na construção direta ou indireta é a concordância, visível principalmente na terceira pessoa plural (ver seção 3.2 sobre concordância e os exemplos em (12) de verbos direto-indiretos de Classe II e (13) de verbos direto-indiretos de Classe I). Observe, por exemplo, os verbos em pares em (15a e 15a', 15c e 15c'), (16), (17), (18). (20), (21) e (22a e 22a', 22c e 22c', 22d e 22d'), em que a concordância característica de verbos indiretos com o afixo plural $-t$ para concordar com o nominal dativo na terceira pessoa plural é utilizada, desambiguando as duas formas.

De acordo com Tschenkeli (1958), o uso das marcas do conjunto B de afixos seria acompanhado nesses verbos por uma mudança do sujeito morfológico (o nominal nominativo) para o sujeito lógico (o nominal dativo). Dessa forma, o nominal dativo (o objeto indireto) seria percebido nesses verbos como sendo o sujeito da ação.

Como forma de verificar se o nominal dativo estaria nesses verbos funcionando sintaticamente como o sujeito de forma similar ao que acontece com verbos de Classe IV, Tuite (1998) dá as sentenças em (17) e (22d e 22d'), em que tanto (17a') e (17b'), quanto 
(22d'), o nominal nominativo ertmanet-i não poderia funcionar como sujeito, já que sua correferência dependeria de outro nominal na sentença. De acordo com o autor, esse tipo de teste de referência serviria como uma das maneiras de se diagnosticar o sujeito semântico em georgiano.

Além da concordância, a ordem de palavras também parece estar correlacionada com a mudança de foco para o nominal dativo, em que na maior parte dos casos - note, por exemplo, as sentenças em (15), (17), (18), (21) e (22b e 22b', 22c e 22c', 22d e 22d') - há a mudança do nominal dativo para argumento inicial nas sentenças, o que parece contribuir para interpretar aquele nominal como foco e também como sujeito na sentença (TSCHENKELI, 1958; TUITE, 1998). O informante que forneceu as sentenças em (18) e sua interpretação, informou, ao ser questionado, que a percepção de quem seria o sujeito da ação estaria correlacionada com o argumento que viria em primeiro lugar na sentença, no caso, por exemplo, da construção indireta em (18a'), o nominal dativo.

Por esses verbos serem de classes distintas (Classe I e II), os efeitos da construção indireta sobre as duas classes vai diferir, havendo importantes diferenças semânticas entre as duas que serão discutidas separadamente, a começar pela Classe II.

Para Tschenkeli (1958a), as marcas do conjunto B de afixos quando usadas com esses verbos, em particular para aqueles de Classe II, transmite a ideia de que alguma coisa acontece ou aconteceu com o objeto indireto, de forma que ele é afetado (betroffen) pela ação. Assim, as marcas do conjunto B apontariam para os beneficiários ou maleficiários da ação, aqueles mais afetados pela ação (TSCHENKELI, 1958).

Segundo o autor, a mudança de marcas é usada para dar diferentes ênfases (Betonung), usualmente, para a expressão da mesma ideia. Dessa forma, quando apenas se quer apontar para a pessoa ou coisa que funciona como o sujeito gramatical, usa-se as marcas em sua função normal. Se quiser, no entanto, enfatizar quem é aquele afetado pela ação, usa-se as formas invertidas, como chama Tschenkeli (1958), indicando que o objeto indireto é percebido como sujeito e, usualmente, colocado no começo da sentença.

Em (15a versus 15a'), ainda que a tradução não capte a diferença entre as duas construções, as sentenças têm significados distintos. Na primeira, a construção direta, a sentença tem uma interpretação equivalente à tradução. Na segunda, a construção indireta, o evento em si é o mesmo - i.e., o evento de o ladrão escapar dos policiais - no entanto, o foco (ou 'ênfase' como usa Tschenkeli (1958a)) recai no argumento dativo, a 
perspectiva desloca-se para p'olicieleb-s, os 'policiais', que são afetados pelo fato do ladrão lhes ter escapado.

Tuite (1998) aponta a construção indireta como provocando nesses verbos, além de um deslocamento de caráter psicológico para o argumento dativo - i.e., aquele afetado pelo evento e que possui pouco controle ou volição sobre ele -, também uma mudança em empatia. Empatia, na definição de Kuno e Kaburaki (1977), se refere à identificação do falante com diferentes elementos em uma sentença, isto é, sob a perspectiva de qual participante o falante escolhe se posicionar ao descrever o evento. Nesse sentido, as sentenças em (15a, 15c' e 21a') a empatia recairia sobre o participante no dativo, o falante se posicionando sob a sua perspectiva. Já as sentenças em (15a, 15c e 21a) seriam mais neutras, no sentido de serem mais narrativas, apenas reportando o evento (KUNO \& KABURAKI, 1977).

De forma similar a (15a e 15a'), nas sentenças (15c versus 15c') e (21a versus 21a'), o foco se desloca para o argumento dativo plural que concorda com o verbo, moc'ape-eb-s e chem-s mshobl-eb-s respectivamente, em que eles são afetados pelo evento, acarretando seu pouco ou nenhum controle sobre o evento. No caso desses dois exemplos, o nominal dativo é animado e o nominativo é inanimado.

Nas sentenças (15b versus 15b') a interpretação indireta do mesmo verbo provoca, não só a mudança de foco para o argumento dativo deda-s, mas também a implicação de que é a mãe que vê a criança em seu sonho, embora, naturalmente, não possua controle sobre o evento. O mesmo acontece com as sentenças em (16a versus 16a') em que, enquanto a sentença na construção direta em (16a) implica que as crianças apareceram intencionalmente diante de suas mães, a sentença na construção indireta em (16a') acarreta o deslocamento de foco psicológico para o argumento dativo, em que as mães veem as crianças aparecendo em seu sonho.

Os exemplos (17a versus 17a') e (17b versus 17b') não necessariamente implicam uma mudança de foco de um argumento para o outro, já que, evidentemente, o objeto, nesse caso, é correferencial com o sujeito. Como observa Tuite (1998) ao discutir os exemplos, o deslocamento de perspectiva ocasiona uma interpretação não intencional na construção indireta em (17a' e 17b'), enquanto a construção direta (17a e 17b) somente pode ser interpretada como uma atividade intencional.

Da mesma forma, nos exemplos em (18), (19) e (20), a construção indireta - em contraste com as construções diretas - acarreta um forte sentido de não intencionalidade 
e de pouca ou nenhuma volição por parte dos nominais dativos, significado que pode ser transmitido, por vezes, por expressões de não intencionalidade em português como 'por acaso’ em (20), ‘não fazer de propósito’ em (18) e ‘não ter intenção’ em (19).

Ademais, as sentenças em (19) contrastam o uso indireto do verbo de Classe II em (19a) e o verbo direto de Classe I em (19a'); esse tipo de oposição - que reforça as tendências representadas por essas classes (tanto, como é argumentado, as classes marginais quanto as mais centrais) - será explorada nas seções que se seguirão.

Em (16b versus 16b'), a sentença na construção indireta (16b') pode ser interpretada sensorialmente, em que o argumento dativo, 'os cães', é afetado pelo evento, nesse caso, por sentirem o odor. Literalmente, a sentença poderia ser traduzida como 'o odor caiu sobre os cães'.

Em contraste com esses verbos direto-indiretos de Classe II, a construção indireta em verbos de Classe I tem um efeito semântico um pouco diferente.

Os verbos transitivos de Classe I em (22) e (23) adquirem uma interpretação bastante saliente de estatividade resultante da mudança para a construção indireta, interpretação estativa que é recorrente, principalmente, quando há um argumento animado como dativo e outro inanimado como nominativo que é o caso dos exemplos em (22), ou, no caso de (23), quando há ausência do argumento nominativo.

Em razão da semântica desses verbos, a construção indireta ainda pressupõe situações que envolvem pouco ou nenhum controle ou volição por parte dos participantes, já que, normalmente, são situações que denotam eventos psicológicos ou físicos e estados - observe, também, os verbos listados na Tabela 8. Diferente do que ocorre com os mesmos verbos quando usados na construção direta em (22a, 22b, 22c, 22d) e (23a), em que se pressupõe um maior grau de volição e intencionalidade por parte do sujeito nominativo que, de uma forma ou outra, é responsável pelo evento.

Dessa breve exposição podemos extrair alguns conceitos ou categorias semânticas que serão importantes na discussão que se segue e na caracterização dessas construções marginais. Inicialmente, é possível dizer que certas propriedades semânticas como saliência, agentividade, animacidade, volição/controle estão envolvidas na significação acionada por essas classes e no contraste que geram em relação às construções circundantes. 


\subsection{Verbos indireto-causativos}

Verbos transitivos que apresentam alternância entre marcação indireta e direta não são característica exclusiva do grupo de transitivos de Classe I direto-indiretos que foram vistos na seção anterior. Outros pequenos grupos de verbos formalmente transitivos também compartilham essa peculiaridade.

É o caso, por exemplo, de um grupo de verbos morfologicamente causativos discutidos por Tuite (2009). Verbos como esses afastam-se do padrão em um número diferente de modos, são verbos com morfologia causativa, o que os torna formalmente transitivos, porém, o sujeito desses verbos (o causador e agente) pode ser omitido e são, além do mais, verbos considerados indiretos, i.e., ocorrem em construções indiretas. Característica esta que provavelmente é correlata, como o autor menciona, ao fato de serem verbos que, em sua maioria, denotam sensações involuntárias, sintomas, mudanças de estado, etc., semântica típica de verbos com sujeitos experienciadores e, como visto, de verbos de Classe IV em particular.

Uma parte desses causativos monovalentes indiretos, no entanto, pode também alternar para construções diretas. Nesse caso, o significado implicado pela interpretação direta parece ser relativo ao seu uso indireto, ou seja, verbos que expressam processos com pouco ou nenhum controle adquirem, a partir da construção direta, uma interpretação em que o sujeito passa a ter um grau de controle sobre o evento.

Tuite (2009) divide os verbos que chama de agentless transitives 'transitivos sem agente' em três grupos. O primeiro, ilustrado pelos exemplos, a seguir, em (24), (25), (26) e (27) e chamado pelo autor de causativos sem agente facultativos, é composto por verbos morfologicamente causativos que podem alternar entre uma estrutura bivalente (i.e., causativa e direta) e monovalente (sem presença do agente, o causador, e indireta). Semanticamente, segundo o autor, são verbos que denotam sensações corporais involuntárias como tremer, delirar, arrepiar-se, etc.

O contraste entre os usos mono- e bivalente é exemplificado por Tuite (2009) pelas sentenças em (24). A sentença em (24a) é causativa, marcada no verbo $a-k$ 'ank'al$e b$-s pela vogal pré-radical $-a$ - e pelo sufixo temático $-e b$. Como é esperado de uma construção direta transitiva, o agente é marcado, nas Séries II do aoristo, pelo caso ergativo. 
O mesmo padrão pode ser observado pelas sentenças bivalentes em (27b e 27b'), em que o agente é marcado pelo caso nominativo nas Séries I (27b) e pelo caso ergativo nas Séries II (27b'), enquanto o objeto direto é marcado pelo caso nominativo nas Séries II (27b') e pelo dativo nas Séries I (27b). Quando, no entanto, os mesmos verbos morfologicamente causativos $a-k$ 'ank'al-eb-s e $a-z h r z h o l-e b-s$ são usados em sua forma monovalente - i.e., omitindo-se o agente da causativa, aquele que causa o evento apresentam um padrão similar ao de verbos de Classe IV, em que o sujeito é marcado pelo caso dativo nas Séries II (TUITE, 2009).

O objeto indireto, no caso do uso monovalente, é marcado pelo conjunto de afixos B e recebe uma caracterização parecida a sujeitos experienciadores típicos de construções indiretas, como em verbos de Classe IV, em que o sujeito não possui controle sobre o evento, apenas experienciando de alguma forma seus efeitos. O exemplo em (26) ilustra a diferença entre o verbo indireto-causativo em (26a) e o verbo ativo em (26a'): enquanto em (26a'), o sujeito tem controle sobre o evento de alongar-se - sendo, aliás, marcado no verbo pelo conjunto de afixos A -, em (26a), é passado o sentido de não-volicionalidade por parte do sujeito, em que o sujeito experiencia o desejo de alongar-se.

Os exemplos em (25) exemplificam outros verbos causativos sem agente, em que o objeto indireto parece comportar-se como o sujeito experienciador. Em (25b), ainda que o argumento nominativo presente possa ser considerado como o agente da ação, i.e., aquele que causa a situação de 'tremer', é mais provável que o argumento dativo animado, a exemplo de outras construções indiretas já discutidas, esteja sendo considerado como o sujeito experienciador da ação, minimizando uma leitura causativa da sentença. ${ }^{7}$

O segundo grupo dividido por Tuite (2009) consiste em um subgrupo dos verbos chamados por ele de verbos sem agente facultativos, diferindo do anterior apenas por não serem morfologicamente causativos. Alguns exemplos desses verbos estão ilustrados em (28). Semanticamente, são verbos que denotam dores e desconforto muscular (TUITE, 2009).

\footnotetext{
${ }^{7} \mathrm{O}$ significado, ou tradução, da sentença em que o nominal 'minha alma' é posicionado como sujeito foi mantido de acordo com o que foi passado pelo falante, o que é interessante, já que mostra que o falante percebe o argumento dativo como sujeito.
} 
(24) Causativos sem agente facultativos

a. shish-ma isev a-m-a-k'ank'al-a

medo-ERG novamente PV-1B.SG-PRV-tremer-3AERG.SG.AOR.INDIC

$\mathrm{O}$ medo me fez tremer novamente.

a'. siciv-isa-gan a-m-a-k'ank'al-a

frio-GEN-POSP PV-1BDAT.SG-VPR-tremer-3ANOM.AOR.INDIC

Eu tremi de frio.

[Adaptados de Tuite (2009)]

(25) Causativos sem agente facultativos

a. me m-a-caxcax-eb-s rodesac v-uqur-eb

1SG.DAT 1BDAT.SG-VPR-ter.medo-ST-3ANOM.SG quando 1ANOM.SG-olhar-ST

lom-s

leão-DAT

Eu tenho medo quando olho para um leão.

b. chem-s sul-s a-trtol-eb-s shen-i siqvarul-i

meu-DAT alma-DAT VPR-tremer-ST-3ANOM.SG seu-NOM amor-NOM

Minha alma treme por seu amor.

c. me m-a-bod-eb-d-a rodesac m-kond-a

1SG.DAT 1BDAT.SG-VPR-delirar-ST-SA-3ANOM quando 1BDAT.SG-ter-3ANOM

sicxe

febre.NOM

Eu delirava quando tive febre.

(26) Verbo causativo sem agente em (a) e verbo ativo em (a')

a. ga-m-a-zmor-eb-s

PV-1BDAT.SG-VPR-alongar-ST-3ANOM.SG

Eu sinto a necessidade de me alongar.

a'. ga-v-i-zmor-e

PV-1AERG.SG-VPR-alongar-AOR.INDIC

Eu me alonguei. 
(27) Marcação de caso em verbos indireto-causativos monovalentes e bivalentes.

a. xazarula-s siciv-isa-gan a-zhrzhol-eb-s xazarula-DAT frio-GEN-POSP VPR-tremer-ST-3ANOM.SG

A xazarula (nome de árvore) estremece do frio.

a'. xazarula-s siciv-isa-gan she-a-zhrzhol-a xazarula-DAT frio-GEN-POSP PV-VPR-tremer-3ANOM.SG.AOR.INDIC A xazarula estremeceu do frio.

b. kal-s usiamovno mogoneba a-zhrzhol-eb-s. mulher-DAT desagradável lembrança.NOM VPR-tremer-ST-3ANOM.SG Uma lembrança desagradável faz a mulher tremer.

b'. kal-i usiamovno mogoneba-m she-a-zhrzhol-a. mulher-NOM desagradável lembrança-ERG PV-VPR-tremer-3ANOM.SG.AOR.INDIC Uma lembrança desagradável fez a mulher tremer.

[Adaptados de Tuite (2009)]

(28) Verbos sem agente facultativos (não causativos)

a. ga-m-qin-av-s

PV-1BDAT.SG-sentir-se.gelado-ST-3ANOM

Eu me sinto gelado.

b. gverd-shi m-chxvlet-s

lado-POSP 1BDAT.SG-sentir.dor-3ANOM

Eu sinto uma dor lancinante no lado do corpo.

O terceiro grupo divisado por Tuite (2009) é o chamado por ele de verbos causativos lexicalmente sem agente. Diferente do outro grupo de verbos em que a presença do agente é facultativa, esse grupo de verbos é sempre monovalente, i.e., não aparece com um argumento agente. De forma similar aos verbos direto-indiretos vistos na seção anterior, esses verbos podem aparecer tanto na construção direta quanto na construção indireta. A construção indireta implica que a ação é involuntária, não intencional, por parte do sujeito, leitura que pode ser explicada pela semântica desses verbos. Segundo Tuite (2009), seriam verbos característicos do que chamam de 'emanação corporal', denotando reações involuntárias provocadas por estímulos internos corporais, ainda que parcialmente controláveis pelo sujeito, como tossir, espirrar, arrotar, 
soltar gases e vomitar. Em razão dessa semântica, verbos como esses também poderiam ocorrer com um objeto, denotando, por exemplo, aquilo que é expelido, observe os exemplos em (32a e 32b) (TUITE, 2009).

A construção direta, em contrapartida, acarretaria o significado de que a ação é intencional ou que foi feita de propósito.

O contraste entre as duas construções pode ser visualizado em (29) e (30). Enquanto a construção indireta em (29a) e (30a), e também em (31), denota ações involuntárias de 'tossir', 'vomitar' e 'bocejar', a construção direta em (29a') e (30a') denota ações intencionais por parte do sujeito, controladas ou voluntárias.

A diferença na marcação de caso também pode ser observada em relação ao uso indireto e direto desses verbos, o verbo usado na construção indireta em (29b) tem marcação similar a verbos de Classe IV nas Séries II do aoristo em que o sujeito permanece no caso dativo, em contrapartida, na construção direta em (30a) o verbo tem a marcação usual de verbos ativos, em que o sujeito fica no caso ergativo nas Séries II.

(29) Causativos sem agente lexicais

a. c'amosvl-is dghe-s gaciebuli vq'opilvar, sashinlad partida-GEN dia-DAT resfriado 1SG.estar.PERF terrivelmente m-a-xvel-eb-d-a. 1BDAT.SG-VPR- tossir-ST-SA-3ANOM

No dia da partida eu fiquei resfriado, eu tossia terrivelmente.

a'. didi k'ac-ivit much'-shi v-a-xvel-eb grande homem-como palma-POSP 1ANOM.SG-VPR-tossir-ST Como um adulto eu tusso na minha mão.

b. mas da-a-xvel-a

3SG.DAT PV-VPR-tossir-3ANOM.AOR.INDIC

Ele tossiu.

[Adaptados de Tuite (2009)]

(30) Causativos sem agente lexicais

a. rac v-ch'am-e, gadmo-m-a-rc'q-i-a que 1AERG.SG-comer-AOR.INDIC PV-1BDAT.SG-VPR-vomitar-SM-3ANOM Eu vomitei o que comi. 
[Retirado de Rayfield (2006)]

a'. bavshv-ma gadmo-m-a-rc'q-i-a

criança-ERG PV-1BDAT.SG-VPR-vomitar-SM-3ANOM

A criança vomitou em mim.

(31) Causativos sem agente lexicais

a. ertxel kimi-is lekcia-ze da-m-a-mtknar-a

uma.vez química-GEN aula-POSP PV-1BDAT.SG-VPR-bocejar-3ANOM.AOR.INDIC

Uma vez eu bocejei em uma aula de química.

a'. da-v-a-mtknar-e

[Adaptado de Tuite (2009)]

PV-1AERG.SG-VPR-bocejar-AOR.INDIC

Eu bocejei intencionalmente.

[Adaptado de Hewitt (2005)]

(32) Causativos sem agente lexicais

a. zog-i haer-s iolad amo-a-boq'in-eb-s

algum-NOM ar-DAT facilmente PV-VPR-arrotar-ST-3ANOM.SG

Alguns bebês arrotam ar facilmente.

b. sisxl-i amo-v-a-xvel-e

sangue-NOM PV-1AERG.SG-VPR-tossir-AOR.INDIC

Eu tossi sangue.

[Adaptados de Tuite (2009)]

\subsection{Verbos depoentes}

Os verbos chamados de depoentes em georgiano são aqueles que, de um ponto de vista morfológico, comportam-se, aparentemente, como verbos regulares passivos, mas que, de um ponto de vista semântico, possuem uma interpretação ativa (TUITE, 2002).

Sob a luz da morfologia verbal georgiana, esses verbos são comumente classificados como verbos de Classe II, por possuírem um conjunto de características e 
comportamentos similares em termos, principalmente, morfológicos, mas também dividindo algumas características sintáticas em comum.

Os verbos depoentes pertenceriam, assim, aos chamados verbos passivos prefixais, que são aqueles formados ou derivados a partir da vogal pré-radical $-i$ - em adição ao sufixo temático -eb-. No entanto, não possuem uma semântica passiva típica de verbos passivos da mesma classe como é esperado, comportando-se, semanticamente, como verbos ativos, isto é, o sujeito não é paciente, mas sim agente da ação (observe exemplos em (33), (34), (35), (36), (37), (38)), a seguir.

A fim de facilitar a referência aos verbos depoentes com suas diferentes características e formação, optamos por usar, tanto nos exemplos abaixo, quanto ao longo do texto, a divisão dos verbos depoentes em três tipos feita por Tuite (2002) que reflete similaridades semânticas e sintáticas entre eles, além de considerar a valência da base da qual eles seriam derivados.

Os três tipos em que os verbos depoentes são agrupados por Tuite (2002) são: Tipo 1, agrupa os verbos depoentes (somente absolutos, i.e., ) derivados, em sua maioria, de verbos trivalentes, isto é, formados a partir de verbos com três argumentos, havendo o que parece ser a omissão do objeto indireto da estrutura argumental. Observe os verbos depoentes em (36b) e (37), comparando o exemplo (36b) com o verbo passivo correspondente em (36c) e bitransitivo em (36a). Nesses verbos, o objeto indireto é omitido, normalmente constituindo a pessoa a quem a ação do verbo é dirigida ou destinada, mantendo o que parece ser o objeto direto, a ideia ou objeto a ser transferido. Além de permanecer com a mesma diátese do verbo base, isto é, uma semântica ativa.

Semanticamente, de acordo com Tuite (2002, p. 6), o objeto indireto omitido, aquele que receberia a informação, o objeto etc., não seria relevante no momento de fala ou então seria pressuposto pelo falante, ou mesmo estaria na perspectiva do falante;

Tipo 2, agrupa os verbos depoentes (somente absolutos) derivados a partir de verbos transitivos, havendo a omissão do objeto direto da estrutura argumental; Tipo 3, agrupa os verbos depoentes (incluem verbos relativos) derivados a partir de verbos transitivos ou de verbos intransitivos de Classe III, havendo o aumento no número de argumentos. Dentre os verbos de Tipo 3, há ainda os verbos depoentes comitativos chamados aqui de Subtipo 3 para diferenciar dos demais -, derivados exclusivamente de verbos intransitivos de Classe III e diferenciando-se destes por haver um aumento no 
número de argumentos. Não possuem, no entanto, correspondentes absolutos, somente relativos. Os verbos comitativos serão exemplificados e discutidos na seção seguinte.

Os verbos de Tipo 2 estão exemplificados em (33), (34) e (35) e os de Tipo 3 em (38) e (39). Como pode ser observado, em específico, pelas sentenças em contraste em (33) e (35), o objeto direto presente nas sentenças transitivas em (33a') e (35b) é omitido nas construções com os verbos depoentes de Tipo 2 em (33a) e (35a' e 35b), assim como nos exemplos listados em (34). Já com o verbo de Tipo 3 em (38) é observada apenas a mudança de significado, não havendo alteração no número de argumentos em relação ao verbo derivado intransitivo de Classe III $q$ 'ep-s. Segundo Tuite (2002), enquanto este último teria um significado menos específico e marcado, o depoente em (38) seria usado para enfatizar a duração ou o caráter habitual da atividade. Em (39), o verbo depoente absoluto i-p'ranch'-eb-a e seu correspondente relativo em (39b) são derivados do verbo transitivo p'ranch'-av-s, havendo a omissão do objeto direto.

(33) Verbo de Tipo 2 em (a) e verbo transitivo em (b)

a. is i-gin-eb-a (*mtavroba-s).

3SG.NOM PRV-xingar-ST-3ANOM.SG government-DAT

Ele fica xingando, está ocupado em xingar (*o governo).

a'. is a-gin-eb-s mtavroba-s

3SG.NOM PRV-xingar-ST-3ANOM.SG governo-DAT

Ele xinga o governo.

[Adaptados de Amiridze (2006)]

(34) Verbos de Tipo 2

a. ras i-rt'q'mevin-eb-i?!

por que VPR-bater-ST-2ANOM.SG

Por que você fica batendo?! [lit. por que você bate?]

b. k'argi-a, nu i-cingl-eb-i!

bom-COP NEG VPR-choramingar-ST-2ANOM.SG

É o bastante, pare de choramingar!" 
c. sup-shi rat'om i-purtx-eb-it?

sopa-POSP por que VPR-cuspir-ST-2ANOM.PL

Por que você continua cuspindo na sopa?

d. shexe, rogor dga-s da i-ch'qit'-eb-a

olhar.IMP como ficar.3ANOM.SG e VPR-olhar.estupefato-ST-3ANOM.SG

Olhe como ele fica ali olhando estupefato.

e. is i-coxn-eb-a

3SG.NOM PRV-morder-ST-3ANOM.SG

Ele fica mastigando, mastiga continuamente [enfatiza a natureza repetitiva da ação de mastigar].

[Adaptados de Tuite (2002)]

(35) Verbo de Tipo 2 em (a) e (a') e verbo transitivo em (b)

a. chvil-i i-k'bin-eb-a.

criança-NOM PRV-morder-ST-3ANOM.SG

A criança morde (quando, por exemplo, a criança já está na fase de ganhar novos dentes e gosta de ficar mordendo alguma coisa). [Adaptado de Amiridze (2006)]

a'. dzaghl-i i-k'bin-eb-a.

cachorro-NOM PRV-morder-ST-3ANOM.SG

O cachorro morde.

b. chvil-i m-k'en-s

criança 1BDAT.SG-morder.3ANOM.SG

A criança me morde.

(36) Verbo depoente de Tipo 1 em (b), verbo passivo em (c) e verbo bitransitivo de Classe I em (a).

a. mdivan-i kal-s pul-s a-dzlev-s secretária-NOM mulher-DAT dinheiro-DAT VPR-dar-3ANOM.SG

A secretária dá dinheiro à mulher

b. mdivan-i pul-s i-dzlev-a secretária-NOM dinheiro-DAT VPR-dar-3ANOM.SG

A secretária está dando dinheiro.

c. kal-s pul-i e-dzlev-a mulher-DAT dinheiro-NOM VPR-dar-3ANOM.SG

Dinheiro está sendo entregue à mulher. 
[Adaptados de Tuite (2002)]

(37) Verbo depoente de Tipo 1.

a. k'orisp'ondent'-i i-uc'q'-eb-a raion-is axal ambeb-s correspondente-NOM VPR-transmitir-ST-3ANOM.SG região-GEN novo notícias-DAT O correspondente está transmitindo (transmite regularmente) as últimas notícias da região.

[Adaptado de Tuite (2002)]

(38) Verbo depoente de Tipo 3

a. dzaghl-i i-q'ep-eb-a

cachorro-NOM VPR-latir-ST-3ANOM.SG

O cachorro late toda hora, tem o hábito de ficar latindo (de forma inapropriada, desnecessária).

[Adaptado de Tuite (2002)]

(39) Verbo depoente de Tipo 3 absoluto em (a) e relativo em (b).

a. p'at'ara dzaghl-i i-p'ranch'-eb-a.

pequeno cachorro-NOM VPR-flertar-ST-3ANOM.SG

O pequeno cachorro faz pose/graça.

b. $[\ldots]$ da aravis e-p'ranch'-eb-i.

e ninguém.DAT VPR-flertar-ST-2A.NOM.SG

[...] e você não flerta ninguém.

Ao comparar alguns verbos depoentes em georgiano aos verbos depoentes do latim tardio, Tuite (2007, p. 11) diz que a relação entre essa espécie de verbo e a semântica característica associada a eles seria estruturalmente condicionada. De acordo com o autor, os verbos depoentes do georgiano (em particular aqueles agrupados como Tipo 3 e 2 acima) se assemelhariam aos verbos depoentes latinos surgidos no período da Antiguidade Tardia, em que houve um aumento significativo no número de novos verbos depoentes surgidos da voz passiva no latim tardio, derivados de verbos ativos de mesma raiz (TUITE, 2007, p. 11). 
Semanticamente, tanto alguns dos verbos depoentes georgianos de Tipo 3 e 2 quanto os verbos depoentes atestados no latim tardio apresentam, comparativamente aos verbos ativos de mesma raiz, uma mudança de foco para a ação em si e sua relação com o sujeito, de modo a chamar a atenção para o comportamento do sujeito (TUITE, 2007, p. 11).

Essa mudança de foco para a ação que está sendo praticada e seus contornos, e não para o seu resultado, é parte de uma maior proeminência atribuída ao agente da ação. A diferença fundamental que parece existir entre um verbo passivo e um verbo depoente, em uma situação em que ambos são derivados de um verbo transitivo, é que, enquanto o verbo passivo demove o sujeito da ação e dá maior proeminência ao paciente, i.e., aquele que está sendo afetado pela ação, o verbo depoente, em contrapartida, apaga o objeto e dá maior proeminência ao agente e à ação por ele praticada. Nas palavras que Tuite (2007, p. 9) usa "it serves to foreground the grammatical subject AS subject."

O fato de o agente da ação ser trazido para primeiro plano, passando a ter maior proeminência traz como consequência ou implicatura uma maior caracterização do sujeito e de seu comportamento, muitas vezes denotando atividades características daquele sujeito. Situação diferente da reflexividade, ou do sentido mais prototípico da voz média, em que, apesar de o foco voltar-se igualmente ao sujeito, a ação, não somente é praticada pelo sujeito, mas também recai sobre ele próprio ou pode afetá-lo diretamente, isto é, é o sujeito que está sendo afetado pela ação, ou está, em diferentes graus, sob sua própria esfera.

No caso dos verbos depoentes, a ação em si não afeta o sujeito que a pratica, a consequência de uma maior caracterização do sujeito e de seu comportamento decorre de uma maior proeminência atribuída a ele e à ação em si, ou seja, o sujeito acabaria por deslocar o foco para si e a ação, e em certas situações, também decorreria da impressão que sua própria ação acaba por provocar nos outros (cf. TUITE, 2007). Por esse motivo, alguns verbos agrupados como Tipo 2 e 3 acabam por ter, em alguns contextos, uma certa conotação negativa ou incômoda. Alguns exemplos que Tuite (2002) fornece são os verbos $i$-coxn-eb-a 'mastigar' em (34e) e $i$-q'ep-eb-a 'latir' em (38), verbos depoentes de Tipo 2 e 3 respectivamente. Quando referentes ao comportamento de um animal, por exemplo, esses verbos podem implicar uma maior caracterização do sujeito, como uma atividade que é habitual daquele animal ou que faz com frequência. Ou mesmo podem 
enfatizar um aspecto negativo ou incômodo dessa mesma atividade, observe, por exemplo, as construções em (34).

\subsection{Comitativos}

Os verbos depoentes comitativos agrupados como Subtipo 3, diferenciam-se dos outros depoentes de Tipo 3 por adicionarem um objeto indireto através da vogal préradical $-e-$, possuindo uma semântica bastante específica e própria desse subgrupo. $\mathrm{O}$ argumento por eles adicionado corresponde sempre a alguém com quem ou em relação a quem a ação é feita, indicando uma ação feita conjuntamente ou que está associada a tal pessoa. Além disso, os verbos comitativos também se diferenciam dos demais por serem derivados exclusivamente de verbos de Classe III e por apenas apresentarem formas relativas e não absolutas, isto é, não apresentam uma forma com a vogal pré-radical $-i$ -

No que diz respeito a essa última característica, a razão mais provável que esses verbos teriam de não apresentarem uma forma absoluta com a vogal pré-radical $-i-$, seria de não ser necessário - já que, como Amiridze (2006) menciona, os próprios verbos de Classe III dos quais são derivados já servem como uma forma 'absoluta', isto é, uma forma sem a presença de um argumento a mais.

Como se pode observar pelos exemplos a seguir, em termos sintáticos, a única diferença entre os verbos de Classe III e os verbos depoentes comitativos é a presença de um argumento extra marcado pela vogal pré-radical -e-, adicionando um objeto indireto que indica relação de comitatividade. O que parece indicar, a princípio, que a mudança de morfologia, de Classe III à Classe II, está associada à adição de um objeto indireto à estrutura do verbo. De acordo com Harris (1981), essa não seria uma motivação facilmente explicável, i.e., por que a simples presença de um objeto indireto ocasionaria uma mudança de morfologia específica a esses verbos.

(40) Verbos comitativos em (a) e (b) e verbos de Classe III em (a') e (b').

a. me adamian-eb-s v-e-lap'rak'-eb-i

1SG.NOM pessoa-PL-DAT 1ANOM.SG-VPR-falar-ST-1ANOM.SG

Eu falo com as pessoas. 
a'. ambav-ze lap'arak'-ob-s

fato-POSP falar-ST-3ANOM.SG

Ele fala sobre o acontecimento.

b. dzaghl-i tevz-s e-tamash-eb-a.

cachorro-NOM peixe-DAT VPR-brincar-ST-3ANOM.SG

O cachorro brinca com o peixe.

b'. nino k'argad tamash-ob-s

nino.NOM bem jogar-ST-3ANOM.SG

Nino joga bem.

Os verbos comitativos de Classe II, ademais, apresentam nas Séries II alguns comportamentos morfológicos idiossincráticos quanto à marcação de caso. De acordo com a norma, e também com os falantes que parecem seguir esse paradigma, esses verbos têm seus argumentos marcados como esperado, isto é, nominativo para sujeito e dativo para objeto. Em fala considerada coloquial, porém, o sujeito desses verbos, no aoristo das Séries II, é marcado com o caso ergativo ao invés do caso nominativo, e o objeto indireto continua com o caso dativo (cf. ARONSON, 1999; HARRIS, 1981; HEWITT, 1995).

A maior parte dos verbos listados como verbos comitativos são derivados de verbos de Classe III que podemos chamar de inerentemente ou lexicalmente recíprocos, como, por exemplo, conversar/falar, discutir, brigar, flertar, brincar/jogar etc. Em georgiano, assim como em outras línguas, verbos inerentemente recíprocos, quando em presença de um sujeito plural, podem ter um leitura recíproca sem precisar do auxílio de outra marca própria de reciprocidade (AMIRIDZE, 2006, p. 123). Por exemplo, o verbo de Classe III 'tamash-ob', jogar/brincar, na frase "me da anam vitamashet", pode significar tanto a ação ou estado de jogar "Eu e Ana jogamos (aor.)" quanto reciprocidade "Eu e Ana jogamos uma com a outra" (AMIRIDZE, 2006, p.124).

É comum em algumas línguas haver sincretismo ou polissemia entre a marcação (ou construção) de reciprocidade e outros sentidos não-recíprocos, como o sociativo e comitativo (cf. NEDJALKOV, 2007), i.e., a mesma marca ou construção é usada ou passou a ser usada para indicar, além de reciprocidade, outros sentidos relacionados semanticamente. Em certas línguas em que esse tipo de polissemia ocorre, de um ponto de vista sintático, pode haver na construção com sentido comitativo um aumento no número de argumentos em relação à construção base recíproca (NEDJALKOV, 2007, p. 383 e p. 41). 
Em georgiano, em relação aos verbos comitativos exemplificados aqui, esse tipo de polissemia na marcação não ocorre, i.e., a estratégia que normalmente se usa em georgiano para indicar reciprocidade (usando a forma ertmanet-i) não é igual à estratégia ou construção de comitatividade usada pelos verbos depoentes em questão.

O que é interessante notar, no entanto, em primeiro lugar, é a relação próxima que parece existir nas línguas entre os sentidos de reciprocidade e comitatividade, causando em alguns casos que este seja derivado daquele. E em segundo, sintaticamente, entre essas duas construções ou sentidos, há, em certas línguas, um aumento no número de argumentos no sentido comitativo em relação ao sentido recíproco base.

A partir disso, é possível traçar um paralelo com os verbos depoentes comitativos. Como mencionado, a maior parte dos verbos de Classe III que serviram de base aos verbos depoentes comitativos, possuem uma semântica de reciprocidade, isto é, são inerentemente ou lexicalmente recíprocos. Assim, levando em consideração essa relação próxima existente entre os sentidos de reciprocidade e comitatividade, não é uma surpresa que o sentido de comitatividade expresso por esses verbos depoentes tenha sido derivado de verbos que possuem esse tipo de semântica inerente, isto é, de reciprocidade. ${ }^{8}$

Em adição a isso, como visto, há também o aumento de valência do verbo com sentido comitativo em relação à valência da base com sentido recíproco. Em georgiano, a mesma mudança de valência ocorre. Em relação à base, verbos de Classe III com sentido de reciprocidade, há, nos verbos comitativos derivados, um aumento no número de argumentos através do emprego da vogal pré-radical - $e$-.

A hipótese que pode ser levantada é de que a mudança de morfologia e, consequentemente, de classe, está relacionada ao aumento de valência de um verbo para outro. Desse modo, é possível que os verbos depoentes comitativos tenham se apropriado da vogal pré-radical - $e$ - como marca de comitatividade, isto é, como uma 'versão comitativa' (como é chamada por Harris (1981)), tendo como função tornar aquele sintagma nominal comitativo um argumento da estrutura do verbo. ${ }^{9}$

\footnotetext{
${ }^{8}$ Considerando a semântica desses verbos como naturalmente recíprocos - seja com uma derivação de Classe II ou III -, é bem possível que, dependendo do contexto, os verbos comitativos também possam ter uma leitura que indique ou subtenda-se algum tipo de reciprocidade entre os participantes, além do sentido mais geral atribuído a eles de comitatividade.

${ }^{9}$ Um outro indício a favor dessa análise é a possibilidade de as versões verbais poderem ser substituídas por um sintagma nominal posposicionado. Em relação aos verbos comitativos, isso também pode acontecer, só que o sintagma nominal posposicionado comitativo pode aparecer somente com o verbo de Classe III, indicando possivelmente que a mudança de morfologia juntamente com o uso da versão estão associados à marcação do objeto indireto, o nominal comitativo, como argumento do verbo.
} 


\subsection{Em outras línguas: algumas considerações}

Tuite (2007, p. 12) sugere que fenômeno similar àquele apresentado em particular pelos verbos depoentes de Tipo 2 e 3 descritos na seção 4.3, tanto de um ponto de vista semântico quanto sintático, é encontrado no russo, sueco, línguas bálticas (letão e lituano) e em algumas línguas oceânicas (to'aba'ita). A seguir serão traçados, a fim de comparação, alguns paralelos semânticos e morfossintáticos iniciais entre os verbos depoentes em georgiano e fenômenos similares em termos sintáticos e semânticos, em particular, em russo e to'aba'ita.

Em russo, o sufixo verbal -sja (ou -s' após vogais) é comumente conhecido por expressar ou marcar reflexividade, todavia, nem todos os seus usos podem ser explicados ou definidos por essa única propriedade semântica do sufixo, pois, embora o sentido reflexivo seja o significado mais prototípico ou mais 'primitivo' do sufixo, outros sentidos não-reflexivos são igualmente atribuídos a ele (cf. AHN, 2006).

Um dos sentidos não-reflexivos do sufixo -sja é o que Gerritsen (1990, p. 4) e outros descrevem como 'active-objectless' ou o que Ahn (2006, p. 12) chama de 'qualitativo'. Aqui, passaremos a nos referir a esse uso como depacientivo simplesmente.

O uso ativo-depacientivo do sufixo -sja - confira sentença (41b) dos exemplos abaixo, retirados de Medová (2009) do russo - é descrito, semanticamente, como uma ação que pode ser repetitiva ou habitual, ou mesmo característica do sujeito, e ao contrário do seu uso reflexivo, o sujeito não é afetado pela ação. Em (41b), as duas leituras são possíveis, tanto pode significar uma característica do sujeito, isto é, cachorros, em geral, têm uma tendência a morder (este, porém, não), quanto pode expressar uma ação/atividade habitual, o cachorro, nesse caso, usualmente não tem o hábito de morder. 
(41) Em russo

a. Naša sobaka ne kusaet detej.

our dogNOM NEG bite3.SG.PRES childrenACC.PL

'Our dog doesn't bite people.'

b. Naša sobaka ne kusajet.sja

our dogNOM NEG bite3.SG.PRES. sja

'Our dog doesn't bite.'

(MEDOVÁ, 2009, p. 26)

De um ponto de vista semântico, a semelhança é bastante saliente às características de alguns verbos depoentes em georgiano, principalmente de Tipo 2 e 3 que foram descritos anteriormente, como, por exemplo, com o verbo depoente de Tipo 2 i-kbin-eb-a "morder", as sentenças exemplificadas em (35) 'dzaghli i-kbin-eb-a' e 'chvili $i$-kbin-eb-a' sendo casos em questão. Naturalmente, essas sentenças dependem do contexto e podem ter uma variedade de diferentes significados, inclusive tons negativos dependendo do caso. A sentença 'chvili i-kbin-eb-a' por exemplo (em 35a), de acordo com Amiridze (2006) de onde foi retirada, pode estar relacionada a um bebê 'chvili' que esteja na fase em que seus dentes estão crescendo e já poderia morder, mastigar alguma coisa. Diferentemente do contexto, aliás, em que o sujeito/agente fosse um animal.

O que é igualmente interessante e notavelmente similar ao georgiano, é que as sentenças com o uso do -sja ativo-depacientivo em russo são descritas por Medová (2009, p. 28) e Ahn (2006, p. 13) como construções em que o foco ou a proeminência recai no agente e na ação em si através do apagamento do objeto/paciente. Ao contrastar-se a sentença (41a) e (41b) em russo, percebe-se, em uma sentença transitiva como em (41a), que o foco recairia sobre a ação como um todo e sobre o paciente, isto é, o interesse está no que poderia acontecer ao paciente a partir daquela ação praticada pelo agente. Em uma sentença como em (41b) o paciente é colocado em segundo plano, isto é, é rebaixado sintaticamente da estrutura do verbo, fazendo com que maior proeminência recaia sobre o agente e o evento expresso pelo verbo, consequentemente, o objeto da ação torna-se informação não relevante ou necessária. 
Situação bastante semelhante às sentenças em georgiano que acabamos de ver com o verbo $i$-kbin-eb-a, em que, se contrastarmos com sentenças transitivas, veremos que a proeminência nesses verbos depoentes recai sobre o agente e o evento em si, ou seja, o foco está em chvili/dzaghli e seu comportamento, o objeto torna-se informação desnecessária ou irrelevante.

De um ponto de vista sintático, ambas as construções, em russo e georgiano, estão diretamente relacionadas à intransitividade. Em russo, a reflexividade com o sufixo -sja é comumente conhecida por estar ligada a uma detransitivização do verbo (AHN, 2006; AMIRIDZE, 2006). Em georgiano, a morfologia de Classe II juntamente com a vogal pré-radical - $i$ - funcionam como marca de detransitivização nesses casos.

Sob uma perspectiva sintática, é possível que a vogal pré-radical - $i$ - possa estar relacionada a uma função depacientiva nesses casos, isto é, estaria funcionando como marca morfológica, juntamente com uma função sintática, de depacientização, processo que envolveria tanto a detransitivização do verbo quanto, consequentemente, mudança argumental ou de valência associada ao verbo, como demoção de objetos.

Em russo, é interessante notar, que o sufixo -sja pode ter ainda sentido passivo, como em “dver' otkryvaet-sya Antonom" 'A porta está sendo aberta por Anton' (MEDOVÁ, 2009, p. 28). ${ }^{10}$ Ou seja, há uma correspondência entre os usos de reflexividade/passividade e o uso ativo-depacientivo, estando os três associados à intransitividade em russo.

Em georgiano, encontramos situação similar, a vogal pré-radical está associada tanto à passividade (verbos prefixais de Classe II) e reflexividade (versão subjetiva e outras estratégias de reflexivização) quanto ao uso depacientivo nos verbos depoentes que foram discutidos até o momento. O uso passivo e depacientivo (verbos depoentes) estão relacionados à intransitividade assim como no russo, no entanto, a reflexividade em georgiano não está associada à detransitivização do verbo, cf. Amiridze (2006, p. 39), pois, de acordo com a autora, para se ter uma leitura reflexiva em georgiano, é necessário, pelo menos, dois argumentos.

\footnotetext{
10 Um fato sintático interessante apontado por Medová (2009, p. 28) acerca da construção ativadepacientiva com -sja é que, de acordo com a autora, o objeto direto demovido não poderia ser expresso como um sintagma nominal oblíquo, o que, segundo ela, é inesperado se considerarmos a construção passiva com -sja, em que o sujeito demovido pode ser ainda expresso como um SN oblíquo (caso instrumental) como no exemplo citado. Essa restrição sintática específica a essa construção com -sja aponta para uma estrutura bastante consistente e própria desse tipo de formação.
} 
Apesar disso, o uso depacientivo em russo e georgiano, parece estar diretamente relacionado a outras funções como passividade e reflexividade, assim como intransitividade. E como será visto acerca da língua to'aba'ita neste momento, relação similar também pode ser encontrada.

Na língua to'aba'ita - pertencente ao grupo das línguas oceânicas da família austronésia - existe a possibilidade de se formar uma construção recíproca morfologicamente, dentre outras formas, através de um prefixo verbal, kwai-, sendo, portanto, a marcação de reciprocidade a função principal ou mais prototípica, porém não única, atribuída a esse prefixo (LICHTENBERK, 2007, p. 1552).

Desse modo, além da reciprocidade, outros sentidos e funções são também atribuídos ao prefixo kwai-, dentre eles e o mais proeminente de acordo com o autor, encontra-se o que Lichtenberk (2009, p. 1559) chama de função 'depacientiva'.

Assim como vimos no russo e georgiano, em uma construção depacientiva com o prefixo kwai- em to'aba'ita, o sujeito é mantido, em comparação ao verbo base, enquanto que o objeto é completamente apagado da estrutura do verbo (LICHTENBERK, 2007, p. 1559). Como pode ser observado pelos exemplos a seguir que o autor contrasta:

(42) Em to'aba'ita

a. Wane e laba-ta'i nau.

man 3sg.fact harm-tr $1 \mathrm{sg}$

'The man harmed me.'

b. Wane baa 'e kwai-laba-ta'i.

man that 3sg.fact depat-harm-tr

'The man harms (people), damages, destroys (things).'

(LICHTENBERK, 2007, p. 1560)

Em (42b), em contraste com a sentença transitiva em (42a), o prefixo kwai- é usado, tornando a sentença intransitiva e passando a marcar o sentido depacientivo. Sintaticamente, o objeto direto é apagado - observe a presença do objeto direto 'nau' em (42a) em oposição à ausência de qualquer objeto em (42b) -, enquanto que, 
semanticamente, sua presença torna-se informação não necessária. Nas palavras do autor, a identidade do paciente é irrelevante ou geral, ou seja, não é dirigida a um participante específico, mas sim a um tipo de entidade ou coisa. Diferentemente da sentença transitiva em (42a) em que o foco recai na ação como um todo e no que pode acontecer ao paciente através da ação praticada pelo agente, isto é, o deslocamento do foco se dá do início da ação ao final, em que o paciente é diretamente afetado.

Em (42b), pelo contrário, o deslocamento do foco ocorre em direção ao sujeito e aos contornos do evento, e não ao seu resultado. Pois o que é relevante é o sujeito wane 'homem' e sua ação, a capacidade de provocar danos, destruir, situação semelhante à que vimos com as sentenças em georgiano com $i$-kbin-eb-a, em que o que interessava não era o que estava sendo mordido ou na sentença em to'aba'ita, destruído (isto é, o paciente), mas sim a ação em si e as características e propriedades atribuídas àquele sujeito.

Dessa forma, o que passa a ser realçado é o agente, a informação passada é a seu respeito, suas características, propriedades ou comportamento. Por isso, usualmente, esse tipo de construção pode indicar uma situação recorrente ou típica, habitual, porém, em certas circunstâncias também pode significar um único ou específico evento, em que o que é relevante é o agente e a atividade desempenhada por ele (LICHTENBERK, 2007, p. 1561).

As semelhanças, tanto semânticas quanto sintáticas, em relação ao que temos discutido aqui acerca dos verbos depoentes, em particular os de Tipo 2, em georgiano e o sufixo -sja em russo, são bastante notórias entre as línguas. Em to'aba'ita, a função depacientiva claramente realça o agente em comparação à construção transitiva, além de poder expressar situações e contextos similares.

Sintaticamente, a detransitivização associada às diferentes funções desses morfemas nessas línguas parece ser um dos pontos em comum entre essas construções. Já que, de acordo com Lichtenberk (2007, p. 1559), a reciprocidade em to'aba'ita também é uma construção intransitiva, em que, diferente do uso depacientivo e em contraste com a base transitiva, codifica o sujeito e o objeto juntos, em que ambos não são, ou não precisam, ser distinguidos, visto que têm papéis idênticos.

Outra construção em to'aba'ita, em alguns verbos, associada ao prefixo kwai- (e à intransitividade), além da reciprocidade e da função depacientiva, é a que Lichtenberk (2007, p. 1563) compara a alguns dos sentidos prototípicos da voz média encontrada em outras línguas. Segundo ele, em certas situações, o sujeito desse tipo de construção age 
sobre si mesmo ou em seu próprio benefício, ou seja, o sujeito ao mesmo tempo pratica e é afetado pela própria ação, diferente do uso depacientivo em que a ação não recai sobre o próprio agente da ação e sim sobre outro participante que não é expresso (LICHTENBERK, 2007, p. 1563).

Essas propriedades são interessantemente similares a alguns dos usos da versão subjetiva do georgiano marcada pela vogal pré-radical - $i$-. Inclusive, a associação desses usos da versão subjetiva à própria voz média não é uma comparação estranha à literatura georgiana (cf. TUITE, 2007, acerca das semelhanças entre voz média e a versão subjetiva).

A associação entre a construção depacientiva nessas três línguas e as diversas funções também marcadas da mesma maneira não parece ser acidental. Em georgiano, a função depacientiva nos verbos depoentes, principalmente os de Tipo 2, estaria sendo marcada da mesma forma que outras construções, isto é, além dela, a vogal pré-radical $i$ - é usada para marcar passividade (em passivas prefixais), assim como é usada em algumas estratégias de reflexivização, e também como marca de versão subjetiva.

Em russo, em relação ao que foi visto aqui, o sufixo -sja, além de marcar o uso ativo-depacientivo, também marca reflexividade e passividade.

Em to'aba'ita, o prefixo kwai-, pelo que foi visto, além da função depacientiva, marcaria reciprocidade e algumas funções atribuídas à voz média.

E como é conhecido na literatura, essas diferentes funções e construções parecem relacionar-se de maneiras diversas nas línguas do mundo, variando de língua a língua, como por exemplo a relação conhecida entre reciprocidade/reflexividade/voz média (cf. GUREVICH, 2006; NEDJALKOV, 2007), ou entre passividade/reflexividade (cf. CYRINO, 2011), em que acabam por ser marcadas da mesma forma. O que vem a se questionar como esse sincretismo viria a acontecer e o porquê de essas construções se relacionarem.

Pelo que foi discutido até aqui, a função depacientiva, que é a que nos interessa no momento, parece estar intimamente ligada a algumas dessas funções. O que levanta as mesmas questões, como essa relação viria a acontecer e por que acontece. Como será discutido no próximo capítulo, de funções mais 'primitivas' ou prototípicas, a função depacientiva parece surgir como uma extensão desses sentidos mais centrais ou iniciais.

Sendo bem menos provável que o inverso tenha acontecido, por exemplo, alguns desses outros usos mais prototípicos da vogal pré-radical - $i$ - tenham surgido a partir do 
uso depacientivo. Pois, em primeiro lugar, não só em georgiano, como em russo e em to'aba'ita, a função depacientiva, se comparada ao uso das outras funções, parece ser mais marginal, já que não parece ser tão produtiva quanto as outras, sendo representada, pelo menos em georgiano, por um grupo de verbos relativamente pequeno se for comparada à formação de verbos passivos de Classe II, por exemplo. No entanto, essa é apenas uma observação preliminar, visto que uma análise diacrônica mais aprofundada desses verbos e sua formação no georgiano antigo é requerida para que se possa verificar qualquer hipótese.

De qualquer modo, Tuite (2007, p. 11) comenta brevemente que sua impressão é que, em suas palavras, esse 'hibridismo' (que ele chama de antipassivização) surgiria quando um morfema reflexivo ou médio teria tomado muitas das funções de uma marca de voz passiva. O que é interessante se levarmos em consideração, além da vogal préradical - $i$ - em georgiano com seu histórico como marca de versão subjetiva e passivização, o morfema -sja do russo, que, como vimos, possui funções de reflexividade e passividade, esta parecendo ser um desenvolvimento posterior daquela (TUITE, 2007, p. 11).

Ademais, essas diferentes funções relacionadas nessas três línguas, além da marcação morfológica em comum, acabam por também assemelhar-se de outras maneiras, seja sintaticamente (pela detransitivização que parece ser um fator em comum), ou semanticamente (por afinidade entre alguns dos seus sentidos). 


\section{GRAMÁTICA COGNITIVA DE LANGACKER E ANÁLISE ALTERNATIVA DAS CONSTRUÇÕES MARGINAIS}

\subsection{Introdução a alguns conceitos básicos da Gramática Cognitiva (CG) de Langacker}

$\mathrm{Na}$ CG, como parte do que Langacker (2008) chama de content requirement - que visa restringir o aparato descritivo a apenas unidades de forma e significado -, as únicas estruturas atribuídas a um sistema linguístico são estruturas fonológicas, semânticas e relações simbólicas entre as duas. Uma relação simbólica, portanto, se dá entre uma estrutura fonológica e uma semântica, constituindo um pareamento de forma e significado (LANGACKER, 1987, 2008). Além desses elementos fundamentais, são ainda permitidas esquematizações dessas estruturas e relações de categorização entre elas.

Esquematização e categorização são processos gerais da cognição humana; esquematização é nossa habilidade de extrair similaridades a partir de diferentes experiências, chegando-se a uma concepção mais abstrata que capta, dessa forma, as similaridades apreendidas entre essas experiências; e categorização, por sua vez, é nossa habilidade de apreender novas experiências a partir de experiências já vividas, de modo a poder associá-las.

Por essa perspectiva, o sistema linguístico seria composto por unidades linguísticas limitadas a pareamentos de forma e significado. Unidades linguísticas convencionais são rotinas cognitivas arraigadas, convencionais à medida que são padrões linguísticos estabelecidos em dada comunidade linguística, e arraigadas, dada a frequência em que são usadas, i.e., quanto mais frequentemente forem usadas ou expostas ao falante, maior o grau de arraigamento dessas unidades.

Por ser um modelo baseado no uso, as unidades linguísticas consistem em abstrações de diferentes graus de eventos de uso, emergindo a partir do arraigamento de aspectos comuns selecionados e apreendidos e tornando-se rotinas cognitivas.

$\mathrm{Na} \mathrm{CG}$, unidades linguísticas são todas aquelas expressões que foram arraigadas através de frequência e convencionalidade, compreendendo tanto itens lexicais, como cachorro, quanto expressões complexas, como, por exemplo, uma sentença transitiva regular. Decorre que, para a CG, não haveria distinção entre gramática e léxico, sendo 
apenas uma questão de gradação entre ambos, e não de componentes discretos, delimitáveis. Desse modo, léxico e gramática (morfologia e sintaxe) formam um continuum, uma gradação em termos de complexidade simbólica, sendo plenamente reduzíveis a estruturas simbólicas, i.e., pareamentos de forma e significado.

Por rejeitar a divisão entre gramática e léxico e acreditar que a gramática contém significado inerentemente, a teoria também rejeita a visão formalista de que a gramática constitui um número limitado de regras e símbolos, sendo a partir desse conjunto restrito que um número infinito de sentenças ou estruturas podem ser produzidas. Pela perspectiva formalista, a sintaxe seria, portanto, o domínio da regularidade e da previsibilidade e o léxico o domínio da irregularidade, da idiossincrasia. Na medida em que o léxico precisa ser armazenado, por ser irregular e imprevisível, a sintaxe, sendo regular e previsível, apenas necessitaria ser computada, gerada a partir de conjuntos de regras, excluindo-se a necessidade de se armazenar as próprias estruturas geradas, pois a regra em si dispensa a listagem das formas produzidas a partir dela.

Para a CG, regras não excluem a presença de listas e tanto o regular quanto o irregular são armazenados. Dessa forma, assim como um esquema mais abstrato como, por exemplo, de formação de plural em $-s$ do inglês é armazenado, as instâncias mais específicas como dogs e cats também seriam armazenadas. A generalização, capturando a regularidade e recorrência dessa formação de plural, é apreendida pelo esquema.

Desse modo, um esquema de formação de plural em -s (ou mesmo um esquema de construções transitivas) é abstraído de instâncias mais específicas que têm em comum a formação de plural, tanto o esquema - presente de forma imanente em suas instanciações -, quanto as formas que o instanciam são armazenados como unidades, diferindo apenas no nível de abstração e especificidade. Nesse sentido, o modelo é bottom-up na medida em que as regras, esquemas mais abstratos extraídos de similaridades entre várias instâncias, emergem a partir do uso.

Assim, para CG, redundância de informação é um fato da língua e não pode ser ignorada a favor de economia, se o que se busca é plausibilidade cognitiva. Expressões mais específicas, arraigadas através de uso repetido, não são excluídas ao se abstrair um esquema de suas similaridades, tanto o esquema quanto suas instâncias coexistem na gramática do falante, sendo rotinas cognitivas arraigadas e facilmente retomadas. Por essa razão, o modelo é não reducionista, já que as instâncias não podem ser reduzidas ao esquema abstraído a partir delas. 
Dessa forma, esquemas abstraídos a partir de similaridades apreendidas de diferentes instâncias mais específicas podem funcionar como templates para a interpretação de novas expressões (LANGACKER, 2008). Na CG, uma relação de categorização é dita de elaboração quando o esquema é plenamente manifestado no alvo, i.e., a instância que o elabora.

Em casos em que a categorização entre alvo e o esquema construcional evocado não é plena, pode ocorrer o que na CG é chamado de categorização por extensão, em que a categorização é apenas parcial, podendo haver elementos ou propriedades que diferem entre alvo e esquema construcional. Essa nova extensão do significado prototípico do esquema, inicialmente não arraigada, pode vir a se tornar uma unidade da língua à medida que começa a ser usada pelos falantes repetidamente. Em dado momento, é possível até mesmo que essa nova construção, tornando-se uma unidade da língua, venha a sancionar ela mesma novas expressões.

Assim, por ser um modelo baseado no uso, a partir do momento que uma construção - que, por exemplo, antes era dada como não convencional - passa a ser usada pelos falantes com maior frequência, pode vir a ser arraigada como unidade, tornando-se parte das expressões convencionais daquela língua.

Naturalmente, o processo de categorização por parte dos falantes vai estar condicionado ao julgamento dos próprios falantes, ao contexto e a outros fatores como, por exemplo, o grau de arraigamento da unidade a ser evocada, i.e., quanto maior a frequência que for usada, mais arraigada será e maior a probabilidade de ser evocada como unidade categorizante.

Dessa forma, esquemas, como unidades arraigadas, não só representam padrões de convencionalidade na língua, mas também participam no processo de mudança da língua, já que é a partir deles que novas expressões podem ser sancionadas e, com uso repetido, se tornarem arraigadas e parte da língua.

\subsection{Construções marginais e contraste semântico}

Mudanças estruturais, como aquelas mobilizadas pelos grupos de verbos vistos até agora, marcam ou são reflexo de diferentes sentidos ou significados. E por mais que essas mudanças estruturais se assemelhem a estruturas de outras construções do sistema, nem sempre o significado que as motiva é igual ou equivalente; e como será argumentado, 
as propriedades de significação que estão sendo mobilizadas podem interagir de diferentes modos tanto entre esses próprias construções marginais como entre elas e as construções circundantes das quais mais se aproximam.

Considerando a estrutura da língua como um sistema de oposições em diversos níveis, frequentemente é observado pela literatura que determinadas construções seriam mais básicas que outras na medida em que usualmente não são marcadas pela língua, enquanto que construções derivadas, isto é, que se distinguem por oposição às primeiras, seriam marcadas. Naturalmente, nem toda diferença em marcação - ou oposição encontrada na língua em termos de construções distintas - implica necessariamente que uma seja básica e a outra derivada, não é raro que se encontrem construções que se oponham tanto semântica e morfologicamente e que sejam igualmente 'básicas'.

E o que temos nos referido aqui como as grandes tendências da língua - podendo ser indicadas através de certos padrões, em termos de construções, observáveis por meio de generalizações como as classes -, fornecem um exemplo disso: verbos chamados tradicionalmente de Classe IV, como já mencionamos, distinguem-se dos demais verbos por ocorrerem somente em construções indiretas em todas as Séries, contrastando em relação a esses por serem verbos com uma semântica bastante particular, usualmente apresentando sujeitos caracterizados como experienciadores, isto é, que não possuem nenhum tipo de volição sobre o evento, comparados a verbos ativos, por exemplo. Nesse caso, a falta de volição característica desses verbos parece ser especialmente marcada pela construção indireta em contraste com o sentido básico de verbos ativos de Classe I, o que, a princípio, poderia nos fazer concluir que verbos de Classe IV não são 'básicos' e sim derivados.

No entanto, como mencionado na seção 3.1.1, para grande parte das raízes verbais agrupadas como Classe IV, o padrão indireto é o básico e, consequentemente, o não marcado para esse tipo de raiz (cf. TUITE, 1998), ou seja, são raízes verbais não derivadas e que, por default, ocorrem em construções indiretas. Dessa forma, tanto a construção indireta que ocorre com verbos de Classe IV quanto a construção direta com verbos transitivos de Classe I por exemplo, podem ser consideradas como construções contrastantes básicas e não derivadas em georgiano.

Imagina-se, a partir disso, dois extremos. De um lado, encontram-se verbos que usualmente aparecem em construções diretas, prototipicamente verbos transitivos de Classe I, do outro lado, encontram-se verbos que ocorrem em construções indiretas, 
prototipicamente verbos de Classe IV. Inerente e indissociavelmente, cada um desses extremos contém suas próprias significações.

É possível pensar, por esse lado, em casos de alternâncias - similares aos exemplos que temos vistos - que ilustrariam ambos os extremos como constituindo padrões básicos na língua. Assim como há verbos que são prototipicamente verbos de Classe I e que alternam para a construção indireta, também o contrário ocorre. A alternância entre as duas construções em (43), por exemplo, ilustra um caso desses, em que a construção indireta poderia ser considerada como default. O verbo em (43a) pertence tradicionalmente à Classe IV e faz parte das raízes que são consideradas básicas e não marcadas para esse tipo de classe e, consequentemente, para a construção indireta; já a construção direta equivalente em (43b) contém um verbo que pertence morfologicamente à Classe I e é derivado do verbo de Classe IV. É interessante notar que, ao contrário dos exemplos de verbos direto-indiretos que discutimos anteriormente, a mudança de uma construção para outra em (43), implica igualmente em mudança de morfologia de classe, ou seja, embora sejam verbos de mesma raiz, possuem morfologia de classe distinta (observe, e.g., a marcação de caso).

(43) Contraste entre verbo de Classe IV (a) e verbo transitivo de Classe I (b)

a. me uceb she-m-dzul-d-a

1SG.DAT de repente PV-1B.DAT.SG-odiar- PI-3ANOM.SG.AOR.INDIC

papa

mingau-NOM

Eu detestei o mingau inesperadamente (não pude controlar).

b. me uceb she-v-i-dzul-e

1SG.ERG de repente PV-1AERG.SG-VPR-odiar-AOR.INDIC mingau.NOM Eu detestei logo o mingau (deliberadamente).

[Adaptados de Amiridze (2006)]

Desse modo, exemplos de mudança como (43) podem ser considerados como casos representativos de um desses padrões, a mudança de significado, conjuntamente com a mudança estrutural, parte de um default (43a) - em que o sujeito experienciador não tem controle sobre o evento - e se aproxima do outro extremo, em que, 
prototipicamente, o sujeito possui um grau de controle sobre a situação. Casos como esses são o oposto de casos em que o verbo por default é de Classe I, isto é, implica um evento em que os participantes possuem controle ou volição sobre o evento, e alterna para a construção indireta, passando a indicar pouco controle por parte dos participantes sobre aquela mesma situação - como, e.g., alguns verbos direto-indiretos de Classe I - fazendo com que se aproxime do significado de verbos indiretos de semântica estativa.

É provável que, ao observar o contraste presente em grupos de verbos menores (como os direto-indiretos) entre construção direta e indireta e suas respectivas significações, a primeira reação fosse procurar associar igualmente cada construção a um desses extremos, já que, muito naturalmente, seus significados carregam inegáveis similaridades àqueles presentes em cada um desses extremos, de modo que a alternância de significado observada de uma para outra construção se daria necessariamente por uma aproximação aos significados indissociáveis de cada construção representada em cada extremo.

Por um lado, isso ocorre na medida em que a construção indireta em particular carrega fortemente consigo a ideia de eventos em que os participantes possuem pouco controle ou volição, dessa forma, a maior parte dos verbos de cada um dos grupos menores comentados, quando usados na construção indireta, acarretam, em menor ou maior grau, a ideia de que os sujeitos não têm controle ou volição sobre a ação. Por outro lado, porém, as correspondências de significado envolvendo essas construções indiretas entre esses grupos, e entre eles e os verbos de Classe IV, não são tão exatas quanto aparentam à primeira vista.

A princípio, uma série de características ou noções semânticas, além de volição ou controle, podem ser identificadas como participando de uma ou outra daquelas construções, e.g., animacidade, saliência, agentividade, etc., noções estas que de forma alguma estão confinadas somente a essas construções - algumas delas são frequentemente citadas, por exemplo, para definir graus de transitividade nas línguas (cf. HOPPER \& THOMPSON, 1980; WOODS, 2008) -, estando presentes em diversas relações observadas na língua ou nas línguas em geral. O que, a priori, parece nos indicar que aspectos mais gerais podem estar sendo espelhados através dessas características recorrentes, além, naturalmente, de nos fornecer indícios de como os falantes atribuem significado a situações e eventos por meio da língua e sua estrutura. 
Dessa forma, a significação por trás dessas construções envolve a mobilização de diferentes características ou noções semânticas, e a interação de forma distinta entre essas noções é parte do processo que dá origem às diferenças e semelhanças entre as diferentes significações. Interação que igualmente converge de diferentes modos ao relacionar-se com sentidos mais prototípicos associados a determinado verbo. E como nota Tuite (1998), no caso dos verbos direto-indiretos, a diferença de significado entre as duas construções em que aparecem, pode variar de leve, previsível à 'idiossincrática'. Desse modo, seria mais apropriado falar em uma gradiência envolvendo as diferentes significações (resultado de interações variadas) do que distinções absolutas e categóricas. Se, então, alternâncias como (43) poderiam mais facilmente ser aproximadas a um dos extremos, construções como aquelas de verbos direto-indiretos estariam, provavelmente, em algum lugar entre esses dois extremos, tanto pelo fato de, em alguns casos, criarem uma certa dificuldade de se definir qual das formas seria realmente a mais básica, quanto, sobretudo, pelo fato de suas significações se distinguirem ou se afastarem de um modo ou de outro daquelas dos extremos, principalmente em relação à interpretação indireta.

Essa interação, mencionada há pouco, com os sentidos mais prototipicamente associados a determinado verbo é, na verdade, mais complexa à medida que envolve a própria percepção e intuição que os falantes possuem das particularidades daquele evento denotado pelo verbo e, por conseguinte, de sua relação e tipo de envolvimento com os participantes. Novamente, acredita-se que, assim como as tendências maiores e mais produtivas na língua, tendências menores, aquelas que se destacam por se desviarem, em termos tradicionais de classe, desses padrões maiores, nos fornecem igualmente pistas de como isso ocorre e se espelha nas línguas. E justamente, um dos modos de se poder observar esses indícios é por meio da própria mudança que esses grupos menores acabam por apresentar, ou seja, o modo como suas relações são codificadas pela língua.

Essa interação entre formas diferentes de significação - envolvendo a própria intuição e percepção dos falantes - e sua codificação na língua, não somente é observável entre os diferentes grupos de verbos marginais que apresentam alternâncias entre construção direta e indireta, mas igualmente em relação aos outros grupos de verbos marginais, como os depacientivos que, apesar de não envolverem distinções entre construções diretas e indiretas, também espelham esse tipo de interação.

Entre o limiar de outras construções, o grupo de verbos depacientivos, de forma similar a verbos que alternam entre construção direta e indireta, parece formar, em termos 
de significações distintas, uma gradiência em relação às construções circundantes. Significações estas que são fruto, igualmente, de uma interação entre os sentidos prototipicamente associados a cada verbo desses grupos marginais - tanto verbos diretoindiretos quanto depacientivos -, isto é, a codificação do evento e a relação que mantém com os participantes tal como são percebidos e intuídos pelo falante; e a mobilização de sentidos diversos, tais como saliência, agentividade, animacidade, volição/controle, etc.

A relação dessas construções conjuntamente com as significações distintas que propiciam e a marcação peculiar que acabam por se apropriar (no caso de verbos depacientivos, a vogal pré-radical - $i$-) resulta, possivelmente, de sua interação com outras construções das quais podem ter sido derivadas por oposição ou contraste. Esse tipo de interação com outras construções, em línguas em que, por exemplo, construções depacientivas similares ocorrem, apesar de poder tomar formas diferentes dependendo da língua, apresenta semelhanças interessantes em termos de construções que acaba por envolver.

De qualquer forma, assim como discutimos especificamente em relação aos grupos de verbos que alternam entre as construções direta e indireta, parece-nos igualmente que as construções depacientivas, no limiar de outras construções mais produtivas e numerosas na língua, não formam com estas cadeias de distinções absolutas, tanto sincrônica quanto diacronicamente, mas sim parecem formar uma gradiência de significações bastante particulares que envolvem não só uma interação de certas noções semânticas, mas a própria percepção do falante daquela situação em determinados contextos.

Como mencionado na seção 1.1.1, o significado de uma expressão, na CG, não equivale a conceitos, mas sim à conceitualização, termo que procura transmitir o caráter dinâmico desse tipo de processo (LANGACKER, 2008). Dessa forma, o significado de uma expressão engloba como o falante entende aquela expressão, tanto como falante, quanto como ouvinte, além de abarcar qualquer aspecto explorado para a construção daquele significado, como experiências e conhecimento prévios, contexto social, físico, cultural etc.

Assim, o processo de construção conceitual, servindo-se de fontes variadas e de um extensivo substrato conceitual, é altamente elaborado e rico, sendo apenas acionado por significados lexicais e padrões composicionais, i.e., a língua apenas disponibiliza 
instruções ou estímulos para a construção de elaboradas conceitualizações as quais somos capazes de realizar (EVANS \& GREEN, 2006; LANGACKER, 2008).

A partir disso, pressupõe-se que o significado das expressões não é objetivamente discernível nos eventos ou no mundo, o falante ou sujeito da conceitualização pode apreender situações e o mundo de diferentes modos, descrevendo-os de formas distintas. Essa liberdade não só implica uma escolha por parte do falante, mas também faz do significado de uma expressão algo dependente de seu ponto de vista e percepção para ser construído.

A idiossincrasia tradicionalmente observada relativamente às classes circundantes, tanto semântica quanto estrutural, nessas classes marginais de verbos que temos visto até o momento, na verdade, não constitui uma idiossincrasia. E sim, a diferença que mostram serve como indício, e reflexo, de como os falantes, como sujeitos da conceitualização, atribuem significado, fazendo escolhas com base em seu ponto de vista e percepção daquele evento ou situação, das relações envolvidas e, consequentemente, do mundo. Por conseguinte, a estrutura da língua dá pistas de como o falante conceitualiza situações e eventos por meio dos recursos que a própria língua disponibiliza.

A seguir discutiremos o quanto esse pressuposto se sustenta relativamente à significação das construções marginais sob foco, além de vermos a importância de certos processos cognitivos como proeminência e arraigamento nas diferentes mudanças observadas nessas construções.

\subsection{Construal}

Nesta seção, a noção de construal da Gramática Cognitiva de Langacker será introduzida, dada sua importância na caracterização do contraste oferecido por esses conjuntos de diferentes construções.

Construal é nossa habilidade de construir uma mesma situação de modos distintos. Duas expressões podem evocar o mesmo conteúdo conceitual, porém diferir em como esse conteúdo conceitual é construído, dessa forma, não basta descrever o significado de uma expressão com base apenas no seu conteúdo conceitual, o modo como esse conteúdo é construído é fundamental para sua caracterização plena. 
Essas diferenças em construal têm reflexo na estrutura da língua, no modo como cada construção é estruturada. É por meio dos mecanismos oferecidos pela língua - que podem variar de língua para língua - que se torna possível estruturar diferentes conceitualizações, diferentes modos de se construir eventos, seus participantes e a relação entre eles e se desviar das construções mais canônicas.

O contraste observado nessas construções marginais é parte resultado de conceitualizações distintas, refletidas em estruturações que acabam por ser consideradas idiossincráticas do ponto de vista das construções mais canônicas que as circundam.

Por um lado, os mecanismos empregados são aqueles que, de um modo ou de outro, acabam servindo de contraste em relação a outras construções circundantes, tornando-as, por oposição, em construções mais 'marcadas'. Por outro lado, esses mecanismos utilizados para marcar essas diferentes significações são, de certa forma, aqueles 'disponibilizados' ao falante daquela língua, certas marcas seriam aparentemente apropriadas de outras construções, formando em alguns casos uma espécie de família de construções, possivelmente com significações associadas em diferentes graus.

Uma dimensão de construal que particularmente nos interessa é a de proeminência ou saliência. A noção, na CG, envolve nossa habilidade cognitiva de dirigir ou focar a atenção em diferentes elementos ou aspectos de uma situação. Dois tipos de proeminência são de interesse para a descrição das classes marginais sob foco, profiling e alinhamento de trajetor e marco.

Em relações de profiling, perfil é a estrutura ou referente que uma expressão designa dentro de sua base conceitual, i.e., o conteúdo evocado. O perfil, dessa forma, é a estrutura mais saliente em referência à base, i.e., o elemento ao qual se dirige ou se foca a atenção. Por essa razão, uma expressão pode evocar o mesmo conteúdo e diferir apenas naquilo que é perfilado.

Há expressões, no entanto, em que tanto o conteúdo, ou base conceitual, quanto o perfil são idênticos, nesses casos, a diferença semântica entre essas expressões reside em alinhamentos de trajetor e marco distintos. $\mathrm{Na}$ CG, classes gramaticais como verbo e substantivo são definidas semanticamente, assim, um verbo, em contraste com um substantivo, é definido como aquele que perfila uma relação. Alinhamento de trajetor e marco é o tipo de assimetria, em termos de proeminência, que se observa entre os participantes de uma relação perfilada por um verbo. O participante focal primário, o mais 
saliente e sobre o qual se fala ou descreve, é chamado de trajetor. O participante focal secundário, quando presente, é chamado de marco.

Assim como classes gramaticais como verbo e substantivo são definidas na CG conceitualmente, noções como sujeito e objeto também recebem uma caracterização conceitual, diferindo substancialmente da visão formalista, em que ambas noções gramaticais são definidas sintaticamente. $\mathrm{Na} C \mathrm{CG}$, sujeito e objeto são definidos em termos de proeminência, sujeito corresponderia ao nominal que codifica o foco primário (trajetor) em uma relação perfilada por um verbo, enquanto o objeto corresponderia ao nominal que codifica o foco secundário (marco).

E como Langacker (2008) salienta, proeminência, tanto em relação a alinhamento de trajetor e marco quanto profiling, é uma questão de como o falante decide descrever uma situação e não algo que pode ser objetivamente discernível naquela situação, ou seja, por ser um fenômeno conceitual, proeminência reside na forma como apreendemos o mundo e não no próprio mundo de forma objetiva.

E essa liberdade do falante em conceitualizar situações de diferentes modo é essencial para o entendimento das construções marginais e da mudança que apresentam, como veremos.

\subsection{Verbos direto-indiretos e construções circundantes.}

\subsubsection{Comentários introdutórios}

Antes de adentrarmos nos aspectos de construal envolvidos na significação dessas construções, é necessário fazermos uma descrição mais aprofundada do significado dessas construções marginais, assim como sua relação com as construções circundantes.

Para que seja possível fazer essa relação, temos que primeiro definir o que é entendido por construções diretas e indiretas, partindo de um ponto de vista das conceitualizações codificadas e não a partir de aspectos puramente formais. Acredita-se que as construções diretas e indiretas formam cada qual uma categoria complexa na língua. Com isso, queremos dizer que a categorização de seus membros em uma ou outra 
categoria é definida em torno de um protótipo ou protótipos e não por meio de um conjunto de características compartilhadas por todos os membros.

Cada categoria, portanto, vai ter seus membros mais representativos, i.e., cada uma vai apresentar construções, entendidas como pareamentos de forma e significado, mais prototípicas que outras, interligadas por relações de categorização parcial, extensão, ou por categorização plena, elaboração. As relações de extensão entre as construções podendo ser tanto relativas à forma quanto ao significado.

A pertinência de se assumir a existência dessas duas categorias na língua é que elas capturam duas fortes tendências, i.e., representam formas particulares de se codificar certas significações de certa maneira na língua. Não são, no entanto, as únicas tendências observáveis, consistindo apenas uma parcela do rico aparato de construções que, sem dúvida, existem e coexistem na língua e que não serão tratadas aqui, e que igualmente não poderiam ser categorizadas nem em uma nem outra dessas categorias. Nosso intuito é apenas fazer um recorte de modo a chamar a atenção para essas tendências, na medida que são importantes para o entendimento da relação entre as construções marginais sob foco e as construções circundantes.

Da mesma forma, o objetivo não é listar construções que fariam parte de uma ou de outra, mas apenas chamar a atenção para seus membros mais representativos e para sua relação com as construções que chamamos de marginais. Essas categorias, naturalmente, não constituem a única forma de se analisar essas construções e seu significado, até mesmo porque não são delimitáveis e nem se pretende que sejam. A partir de seus membros, como é esperado, essas categorias vem a se interseccionar com outras.

Essas construções, de qualquer forma, poderiam ser consideradas sob outra perspectiva, i.e., podem ser observadas a partir de outros contrastes na língua, nesse caso, estamos apenas considerando o contraste que se observa entre construções diretas e indiretas e sua significação, deixando de lado outras possibilidades de análise.

Acreditamos que o contraste exibido por essas duas categorias envolve duas formas distintas de se construir ou se perceber eventos na língua. Como cada construção vai ter suas especificidades semânticas e estruturais, podemos supor a presença de um esquema mais abstrato, menos específico em relação a cada membro, que captura de forma bastante abstrata e geral algumas similaridades entre diferentes instâncias. Esse esquema, como um pareamento de forma e significado, vai ter uma especificação mais 
geral em cada polo, supõe-se que em termos de significado esse esquema vai abstrair uma maneira de se construir eventos na língua.

As construções indiretas constroem eventos de forma que esses eventos acarretem pouca volicionalidade e controle por parte do nominal dativo, usualmente, animado e, como argumentaremos, foco primário. As construções diretas, em contrapartida, constroem eventos em que se pressupõe volicionalidade e intencionalidade por parte do sujeito ou foco primário. Em termos de forma, de modo mais geral e abstrato, o esquema construcional conteria apenas uma especificação, no caso das construções indiretas, relativa a presença mínima de um nominal no dativo e um lexema verbal. Nas construções diretas, haveria, minimamente, um lexema verbal e um sintagma nominal que teria seu caso gramatical a depender do tempo verbal (séries e screeves).

É importante notar que essa forma de se construir eventos associada ao esquema em cada categoria não é algo objetivamente discernível no mundo ou nos eventos em si, mas constitui uma maneira de se perceber ou construir eventos por parte dos falantes, i.e., depende da escolha do falante. Não existem eventos, ou verbos que os codificam, que são intrinsicamente volitivos ou não, qualquer evento ou verbo que o codifica pode, a priori, ser construído de uma forma ou de outra, uma questão do construal imposto pelo falante, e os verbos direto-indiretos são evidência disso.

Dessa forma, quando falarmos em 'verbos indiretos' ou 'diretos', não estamos querendo impor uma propriedade àquele item lexical, mas sim estamos apenas fazendo referência ao sentido ou construal mais prototípico em que aquele lexema verbal é normalmente usado, podendo, a princípio, ser suscetível a diferentes conceitualizações.

\subsubsection{Construções marginais e construções circundantes}

Como foi discutido no início deste capítulo, o padrão indireto pode ser considerado como o básico e, consequentemente, como o não marcado para parte das raízes verbais agrupadas como Classe IV na literatura, i.e., são raízes verbais não derivadas e que, por default, ocorrem em construções indiretas. Por essa razão, é possível dizer que tanto a construção indireta, tendo verbos de Classe IV como prototípicos, quanto 
a construção direta em verbos transitivos de Classe I por exemplo, podem ser ambas consideradas como construções contrastantes básicas e não derivadas em georgiano, formando padrões bastante arraigados e convencionalizados na língua.

Como já mencionado, o que chamamos aqui de construção direta e indireta não constitui uma categorização com limites bem definidos e delimitáveis - tanto em termos de forma quanto em termos semânticos - ao contrário, o limite entre uma e outra é fuzzy, formando um continuum, cada categoria tendo seus membros ou conjunto de construções prototípicos. Dessa forma, o que é prototípico a cada construção, e o que as tornam características, são certas significações associadas a certos comportamentos ou estrutura gramatical característicos que giram em torno de membros prototípicos, além da ocorrência de verbos que prototipicamente são usados nessas construções.

Verbos chamados de Classe IV, por exemplo, podem ser considerados como prototípicos do padrão indireto. Dentre o comportamento gramatical característico compartilhado por esses verbos, há, por exemplo, a inversão em todas as séries, uso dos afixos do conjunto B para marcar o sujeito no dativo e a preferência por concordar com o objeto indireto no plural na terceira pessoa (ver seção 3.2 sobre concordância). Semanticamente, verbos de Classe IV expressam eventos psíquicos e sensórios, como emoções e sensações, usualmente não volitivos e involuntários, em que o sujeito, usualmente um experienciador no caso dativo, não possui controle sobre a ação, sofrendo ou experienciando de alguma forma seus efeitos. Dessa forma, as noções semânticas mais associadas a esses verbos e, consequentemente, às construções indiretas, são a não volicionalidade e agentividade do argumento dativo, além de ser usualmente animado, em contraste com a construção direta que normalmente vai apresentar o sujeito como tendo volicionalidade e agentividade.

Assim como no exemplo (43) da seção 5.2, os exemplos a seguir mostram o contraste semântico entre essas duas categorias, i.e., entre construções diretas e indiretas. Similar ao contraste em (43) da seção 5.2, os verbos nas sentenças diretas de (44) a (46) desta seção podem ser considerados como derivações dos verbos indiretos contrastantes, devido justamente à semântica mais prototipicamente associada a esses verbos - em (47), ocorre o contrário, havendo a derivação de verbos desiderativos a partir de verbos diretos típicos (nesses casos, agentivos da chamada Classe III).

É importante ainda ressalvar que as categorias que aqui definimos como diretas e indiretas não são equivalentes à transitividade, já que tanto nas construções diretas quanto 
indiretas há construções que poderiam ser consideradas como menos ou mais transitivas, se pensarmos, por exemplo, em eventos com dois participantes versus um participante. Nas construções indiretas, encontramos tanto eventos com um participante como m-din$a v-s$ 'eu durmo', quanto eventos com dois participantes como m-i-qvar-s 'eu o/a amo'. Da mesma forma, nas construções diretas, ocorrem tanto verbos com dois participantes como a-shen-eb-s 'ele constrói alguma coisa', quanto com um participante como musha$o b-s$ 'ele trabalha'.

(44) Verbo indireto em (a) e (b) e verbo direto em (a') e (b')

a. sandro-s u-qvar-d-eb-a nino Sandro-DAT VPR-amar-PI-ST-3ANOM.SG Nino.NOM

Sandro está se apaixonando por Nino (mesmo que não queira).

a'. sandro i-qvar-eb-s nino-s

Sandro-NOM VPR-amar-ST-3ANOM.SG Nino-DAT

Sandro está se apaixonando por Nino (e está fazendo de propósito).

b. me she-m-i-qvar-d-a musik'a

1SG.DAT PV-1BDAT.SG-VPR-amar-PI-3ANOM.SG.AOR.INDIC música.NOM

Eu me apaixonei pela música (sem intenção).

b'. me she-v-i-qvar-e musik'a

1SG.ERG PV-1AERG.SG-VPR-amar-AOR.INDIC música.NOM

Eu me apaixonei pela música (intencionalmente).

(45) Verbo indireto de Classe IV em (a) e verbo direto de Classe I em (a').

a. beka-s e-smin-eb-a musik'a

Beka-DAT VPR-ouvir-ST-3ANOM.SG música.NOM

Beka está ouvindo música (mesmo que não queira ou não precise).

a'. beka u-smen-s musik'a-s

Beka-NOM VPR-ouvir-3ANOM.SG música-DAT

Beka está ouvindo música (e está fazendo intencionalmente).

b. mas mo-e-c'on-a simghera

3SG.DAT PV-VPR-gostar-3ANOM.SG canção.NOM

Ele gostou da música (sem intenção). 
b'. man mo-i-c'on-a simghera

3SG.ERG PV-VPR-gostar-3ANOM.SG canção.NOM

Ele gostou da música (intencionalmente).

(46) Verbos de Classe I

a. mo-v-i-mk'vdarun-e

PV-1AERG.SG-VPR-fingir.de.morto-AOR.INDIC

Eu me fingi de morto.

b. mo-v-i-gizhian-e

PV-1AERG.SG-VPR-fingir.de.louco-AOR.INDIC

Eu me fingi de louco.

c. mo-v-i-sulel-e

PV-1AERG.SG-VPR-agir.como.tolo-AOR.INDIC

Eu me passei por idiota, agi como um tolo.

d. mo-v-i-mdzinar-e

PV-1AERG.SG-VPR-fingir.domir-AOR.INDIC

Eu fingi que estava dormindo.

(cf., por exemplo, o verbo de Classe IV m-din-av-s-'eu durmo')

[Adaptados de Asatiani (1998)]

(47) Verbos desiderativos

a. m-e-mgher-eb-a

1BDAT.SG-VPR-cantar-ST-3ANOM

Eu sinto desejo de cantar, estou no humor de cantar.

b. m-e-cek'v-eb-a

1BDAT.SG-VPR-dançar-ST-3ANOM

Eu sinto desejo de dançar.

c. m-e-cin-eb-a

1BDAT.SG-VPR-dançar-ST-3ANOM

Eu sinto desejo de rir.

[Adaptados de Asatiani (1998)] 
(Compare com os correspondentes agentivos de Classe III v-mgher-i 'eu canto', $v$-cek'v$a v$ 'eu danço' e $v$ - $i$-cin- $i$ 'eu rio').

(48) Contraste de significado entre verbo nas Séries II do Aoristo em (a) e nas Séries III do Perfeito em (a').

a. me a-v-a-shen-e saxl-i megobr-is-tvis 1SG.ERG PV-1AERG.SG-VPR-construir-AOR.INDIC casa-NOM amigo-GEN-para Eu construí uma casa para meu amigo (eu quis construir).

a'. me a-m-i-shen-eb-i-a saxl-i

1SG-DAT PV-1BDAT.SG-VPR-construir-ST-SM-3ANOM.SG casa-NOM

Eu construí a casa. (aconteceu, eu não tinha razão para construir).

(49) Contraste de significado entre verbo nas Séries II do Aoristo em (a) e nas Séries III do Perfeito em (a').

a. davaleba ar da-v-c'er-e tarefa.NOM não PV-1AERG.SG-escrever-AOR.INDIC

Eu não escrevi a tarefa (minha vontade, deliberadamente).

a'. davaleba ar da-m-i-c'er-i-a

tarefa.NOM não PV-1BDAT.SG-VPR-escrever-SM-3ANOM.SG

Eu não escrevi a tarefa (involuntário, não deliberadamente, forçado).

[Adaptados de Asatiani (1998)]

Observe que os verbos indiretos correspondentes nos exemplos de (44) a (47) têm uma semântica característica associada a verbos indiretos de Classe IV, denotando emoções (como em (44)), percepção (como (45)), vontade ou desejo de realizar determinada ação (como em (47)) e estados físicos (como m-din-av-s 'dormir' em (46)). Os verbos diretos, em comparação, possuem um importe semântico típico de uma construção direta, denotando eventos em que o sujeito é agentivo e volitivo, i.e., usualmente tem controle sobre a ação.

Estruturalmente, cada construção apresenta seu comportamento característico (observe, por exemplo, a marcação de caso e o uso de afixos de concordância). 
Esse contraste, a princípio, mostra-nos que ambas construções, sendo básicas na língua, têm fortes importes semânticos associados, indicando o quanto são construções arraigadas, tanto semântica quanto estruturalmente. E como é possível observar, cada construção vai apresentar conjuntos de verbos que prototipicamente ocorrem em cada uma, como Langacker (2009b) discute, verbos são aprendidos no contexto das construções em que aparecem - não em isolamento - e vice-versa, e com o arraigamento e convencionalização do uso do verbo em determinada construção é que se pode dizer que o verbo tem o sentido associado àquela construção, em outras palavras, aquela construção, ou significado associado à construção, faz parte do network de construções, ou sentidos, associadas ao lexema verbal.

Uma categoria formada por um network de construções relacionadas é chamada, na $\mathrm{CG}$, de categoria complexa. Além de relações verticais, i.e., relações elaborativas instanciações mais específicas em relação aos esquemas mais abstratos - há também, em uma categoria complexa, relações horizontais, i.e., relações de extensão a partir de um protótipo - um esquema construcional que constitui o centro da categoria, sendo frequentemente instanciado e evocado para a sanção de novas expressões. Ademais, as relações em um network variam tanto em termos de especificidade, quanto em termos de tamanho, i.e., podendo incorporar outros elementos (LANGACKER, 2008).

Tanto itens lexicais, quanto construções gramaticais podem ser abstraídos através do reforço de similaridades apreendidas. Assim, esquemas construcionais são, por sua vez, abstraídos a partir de itens lexicais específicos, enquanto variantes lexicais resultam inicialmente de sua ocorrência em frames estruturais diferentes, podendo formar em cada caso um network de variantes relacionadas em diferentes níveis de especificidade (LANGACKER, 2008).

No caso de um item lexical, por exemplo, um verbo, uma dimensão de sua complexidade é sua ocorrência em contextos estruturais maiores, assim, a descrição de um item lexical depende de conjunto de frames estruturais em que convencionalmente aparece. Esse frames juntamente com os sentidos que induzem formam um network. Como mencionado anteriormente, um item lexical, como um verbo, não é aprendido em isolamento, pelo contrário, sua aquisição se dá através das construções em que ocorre, tornando-se uma unidade através de arraigamento e convencionalização, i.e., sendo abstraído de eventos de uso a partir de similaridades apreendidas. 
Dessa forma, uma estrutura esquemática, como o frame e o sentido que induz de uma construção indireta, pertence tanto ao network dos sentidos associados a verbos indiretos prototípicos, quanto ao network de construções indiretas.

O que é interessante notar no momento é que, seja qual for a direção da derivação -i.e., verbos indiretos prototípicos sendo usados na construção direta em (44), (45) e (46), ou verbos prototipicamente diretos sendo usados na construção indireta em (47) - os significados aproximam-se dos sentidos prototípicos associados a cada construção. Por exemplo, o verbo m-din- $a v$-s 'dormir', usualmente considerado como uma atividade não intencional ou não agentiva, adquire, quando usado na construção direta, o sentido de uma atividade intencional, sendo executada de propósito. Da mesma forma, verbos diretos agentivos de Classe III como v-mgher-i 'eu canto' adquirem, na construção indireta, o sentido, nesse caso, usual da construção desiderativa - em si, uma construção indireta já arraigada na língua, inclusive sendo produtiva na língua -, expressando vontade ou desejo de cantar, ou seja, uma atividade não intencional ou controlável.

Um indicativo adicional de quanto sentidos de não volicionalidade e não intencionalidade estão fortemente associados às construções indiretas, observe os verbos diretos nas sentenças em (48) e (49). Em (48a) e (49a), os verbos aparecem nas Séries II do Aoristo, sendo marcados como é usual, sujeito no ergativo, objeto direto no nominativo e usando-se os afixos do conjunto A para marcar o sujeito.

Nas sentenças em (48a') e (49a'), os mesmos verbos aparecem nas Séries III do Perfeito, como foi exposto nos primeiros capítulos a respeito do sistema verbal georgiano, verbos de Classe I sofrem inversão nas Séries III, tendo seu sujeito marcado com o caso dativo e referenciado com o conjunto B de afixos. Estruturalmente, portanto, verbos de Classe I, quando usados nas Séries III, assemelham-se a verbos indiretos na construção indireta. Semanticamente, é usualmente atribuído às Séries III um sentido de evidencialidade e resultatividade. No caso dessas sentenças, o sentido passado é o de uma ação não intencional por parte do argumento dativo e que ocorre no passado, em que a vontade ou grau de controle do sujeito é enfraquecida (cf. ASATIANI, 1998). ${ }^{11}$

\footnotetext{
${ }^{11}$ Segundo Asatiani (1998), o sentido de evidencialidade/resultatividade em construções nas Séries III traz uma interpretação de que o falante realiza seu enunciado a partir do resultado da ação, descrevendo ou relatando essa ação tal como 'aparentemente' acha que se deu, já que pode não ter visto ou presenciado a situação em questão, ou por não ter certeza do ocorrido, mesmo sendo o agente, seja por não se lembrar, seja por não ter prestado suficiente atenção.
} 
Pensando na construção indireta como a formar uma categoria complexa, é possível supor que as construções discutidas na seção 3.1 façam parte dessa categoria, relacionadas por relações de extensão e em diferentes níveis de especificidade. O esquema construcional da construção indireta em que verbos de Classe IV prototipicamente aparecem seria o centro da categoria, i.e., o protótipo da categoria complexa. Os esquemas de outras construções, como a construção estativa (em específico os passivos de estado bivalentes) e a construção desiderativa - talvez menos centrais, porém igualmente arraigadas na língua - se estenderiam a partir do protótipo. A chamada construção dativa em georgiano (cf. seção 3.1.3) também figuraria na categoria de construções indiretas, estendendo-se a partir do protótipo e, verticalmente, relacionando-se com outros subesquemas em diferentes níveis de especificidade, por exemplo, um em que certos verbos de morfologia de Classe II costumam ocorrer, outro em que certos verbos de Classe I aparecem.

É interessante notar que cada uma dessas construções diferenciam-se ou mesmo distanciam-se do protótipo devido a certas peculiaridades semânticas e estruturais, além de, em alguns casos, terem como prototípicos verbos de morfologia distintas, i.e., de semântica e formação distintas.

Dentre as similaridades, essas construções possuem sujeitos no caso dativo animados, não volitivos e não agentivos, usualmente experienciadores. Construções dativas e passivos de estado bivalentes apresentam além do argumento dativo animado, um argumento nominativo inanimado. Um fator em comum entre todas essas construções e, particularmente interessante, é a presença do argumento dativo marcado pelas vogais pré-radicais. Ainda mais revelador, é o fato de que todas essas construções parecem dirigir maior saliência e foco ao argumento dativo (cf. discussão nas seções 3.1.1, 3.1.2, 3.1.3 e 3.2 ), voltaremos a esse ponto quando discutirmos a noção de construal na significação desses verbos. Dessa forma, parece-nos que certos comportamentos gramaticais apresentados por essas construções, como a preferência pela concordância com o objeto indireto no dativo, parece ser sintomático da maior saliência atribuída ao argumento dativo.

Dentre as diferenças, há, como mencionado, a ocorrência de verbos de morfologia distintas, com semântica e formação particulares. Enquanto a construção indireta com verbos de Classe IV prototípicos pode ser considerada central, na construção dativa, por 
exemplo, ocorrem verbos considerados de Classe II e I. Passivos de estado, por sua vez, têm verbos de semântica essencialmente estativa.

E as construções marginais sob foco, em específico, aquelas que abarcam os verbos direto-indiretos - no caso desses verbos, quando usados na construção indireta -, ainda que possam ser agrupados na categoria complexa de construções indiretas, são também exemplos de como essas construções distanciam-se do protótipo de diferentes modos, sendo provavelmente uma extensão não só do protótipo, mas também do que chamam de construção dativa, já que podem ser também relacionadas a essas construções (cf. seção 3.1.3).

Assim como em relação à categoria complexa das construções indiretas, as construções diretas também formam na língua uma abrangente categoria complexa, tendo provavelmente como construção central ou prototípica aquela em que prototipicamente ocorrem verbos de Classe I ou mesmo de Classe III, denotando eventos agentivos e volitivos. Como mencionado, esses dois polos formam um continuum, não havendo limites precisos onde um começa e outro termina, nem muito menos é possível encaixar ou classificar todas as construções da língua como pertencentes a uma ou outra dessas categorias. Da mesma forma que o uso desses verbos em construções indiretas, seu uso em construções diretas também provavelmente figura como uma extensão do protótipo da categoria, distanciando-se de diferentes formas, seja em termos de morfologia e formação (como aqueles de Classe II), quanto a possíveis nuances de significado.

É ainda interessante notar, no caso desse grupo de verbos direto-indiretos, que talvez não seja possível a partir dos dados que dispomos, afirmar qual construção, se direta ou indireta, é mais básica ou arraigada no network de sentidos associados a cada verbo. De qualquer forma, o contraste em significação parece estar como base da alternância entre construção direta e indireta desses verbos em específico, uma se definindo em relação à outra.

Em relação a esse grupo de verbos na construção indireta, a significação induzida pelo uso na construção indireta interage com os sentidos prototipicamente associados ao verbo, ou como os falantes tendem a perceber esses eventos, o que torna a previsibilidade do significado variável, no caso dos exemplos de verbos de Classe II ilustrados na seção 4.1, alguns denotam eventos usualmente percebidos como mais volitivos e agentivos como 'esconder-se', 'aparecer', 'encontrar-se', outros têm natureza mais estativa como 
'custar'. No caso de verbos direto-indiretos de Classe I, são eventos em sua maior parte psíquicos como 'incomodar', 'alegrar' e 'interessar'.

Tendo essa interação em mente, é possível apontar similaridades que aproximam o significado desses verbos na construção indireta tanto entre si quanto em relação às construções circundantes. Dentre elas, o caráter não volitivo (não voluntário) e não agentivo (no sentido de não poder controlar a ação) do argumento animado no dativo, acarretando eventos não intencionais. Esse contraste se torna particularmente evidente quando comparamos ao uso desses verbos na construção direta, tanto nos verbos de Classe II, quanto nos de Classe I exemplificados na seção 4.1, os eventos denotados nessas construções - com exceção dos exemplos em que o sujeito nominativo é inanimado como em (15c) e (21a) - implicam ações agentivas e volitivas por parte dos sujeitos. Esse contraste também pode ser observado quando se compara um verbo direto-indireto na construção indireta em (19a) da seção 4.1 a um verbo agentivo de Classe I em (19a').

Note que nos exemplos (15c) e (21a), a sentença que seria o equivalente direto, em contraste com as construções indiretas em (15c') e (21a'), afasta-se semanticamente da categoria que definimos como das construções diretas, já que o evento denotado não pressupõe uma volicionalidade ou intencionalidade por parte do foco primário, nesses casos, um argumento no nominativo inanimado. A construção em (15c), em particular, constitui uma construção absoluta, nos termos da CG (ver seção 5.5).

Em relação à animacidade, o argumento dativo é sempre animado, o nominativo varia, às vezes animado, às vezes inanimado, geralmente sendo inanimado em verbos de Classe I na construção indireta, de forma similar a passivos de estado bivalentes e verbos da construção dativa, em que usualmente o argumento nominativo é inanimado. Assim como acontece com essas duas últimas construções, a inanimacidade do argumento nominativo favorece ainda mais uma leitura estativa na construção indireta.

Além dessa oposição em significado entre eventos volitivos/agentivos e não volitivos/agentivos que forma a base semântica do contraste entre construções diretas e indiretas nesses verbos, outras nuances parecem também ser mobilizadas na significação de alguns dos verbos exemplificados, o que em certos casos parece fazer parte da extensão de significados a partir da construção indireta prototípica.

Uma delas e a mais significativa é a própria natureza dos eventos descritos, como se pode perceber, os verbos, particularmente nos exemplos de (15) a (21) da seção 4.1, não são verbos de semântica típica de Classe IV, i.e., verbos em sua maioria psíquicos. 
Quando usados, no entanto, na construção indireta, esses verbos, em específico os exemplos (15a', 15c' e 21a') passam a denotar eventos em que o participante no dativo parece sofrer ou experienciar os efeitos da ação, ou seja, há um deslocamento de caráter psicológico ou psíquico para esse argumento. De forma que, metaforicamente, esse argumento, nesses casos, se torna uma espécie de maleficiário da ação, sendo diretamente afetado por essa ação, ainda que psicologicamente.

De particular importância para a descrição não só desses verbos, mas também para a caracterização de outras construções indiretas que temos visto, é a noção da CG de construal (ver seção 5.3), em específico, no caso desse grupo de verbos, sua dimensão de proeminência envolvendo alinhamento de trajetor e marco.

Argumenta-se que, além das diferenças semânticas discutidas até o momento, o contraste observado entre construções indiretas e diretas nos verbos direto-indiretos exemplificados na seção 4.1 envolve diferentes alinhamentos de trajetor e marco, i.e., constituem formas distintas de se construir esses eventos denotados pelos verbos, atribuindo-se proeminência a diferentes participantes.

Na maior parte dos exemplos da seção 4.1 - tanto em relação aos verbos de Classe I quanto aos de Classe II exemplificados - as sentenças contrastadas entre construção direta e indireta denotam o mesmo evento, ainda assim são conceitualmente distintas, representando diferentes formas de se construir o mesmo evento.

E esse contraste envolve, como vimos, não só noções semânticas distintas como volição e agentividade, mas também a saliência conceitual de diferentes elementos.

Enquanto nas construções diretas com verbos direto-indiretos o argumento nominativo teria maior saliência, i.e., constituiria, nos termos da CG, o foco primário (trajetor) e o argumento dativo, o foco secundário (marco); nas construções indiretas, teríamos a inversão desse alinhamento, em que o foco primário, o trajetor, seria atribuído ao argumento dativo e o foco secundário ao argumento nominativo.

Dessa forma, sentenças que denotam o mesmo evento, como, por exemplo, em (15) - i.e., tanto a construção direta quanto indireta denotam o mesmo conteúdo em que o ladrão escapa do policial - têm como mais salientes diferentes participantes, em (15a), o foco primário recai no argumento nominativo, 'o ladrão', constituindo possivelmente a versão menos marcada e mais narrativa do evento. Na construção indireta, há o deslocamento de saliência, o foco primário, o trajetor, recai no argumento dativo, 'o policial'. 
Acreditamos que essa diferença em alinhamento de trajetor e marco não só é observável nesse grupo de verbos, mas também, ainda mais visivelmente, nas construções indiretas circundantes, como as construções indiretas com verbos de Classe IV, passivos de estado bivalentes e construções dativas, em que o foco primário parece recair sobre o argumento dativo, o nominal usualmente percebido como o sujeito (cf. a discussão nas seções 3.1.2 e 3.1.3).

E como exposto na seção 5.3, noções gramaticais como sujeito e objeto são caracterizadas conceitualmente na $\mathrm{CG}$ em termos de proeminência, o sujeito seria o nominal que codifica o trajetor da relação perfilada pelo verbo, enquanto o objeto seria o nominal que codifica o marco. Dessa forma, sujeito e objeto seriam as manifestações gramaticais de alinhamento de trajetor e marco, um fenômeno puramente conceitual (LANGACKER, 2008).

Por essa perspectiva, o argumento dativo, codificando o trajetor da relação perfilada pelo verbo, estaria servindo como sujeito nessas construções indiretas.

E um argumento a favor dessa análise provém de certos comportamentos gramaticais que podem ser observados nas construções indiretas, inclusive em verbos direto-indiretos, em particular, a concordância com o objeto indireto, mais evidentemente visível na concordância com a terceira pessoa plural.

$\mathrm{Na} \mathrm{CG}$, comportamentos gramaticais usualmente associados a sujeito e objeto não são usados para definir essas noções, mas sim são tomados como sintomáticos de seu importe conceitual, i.e., de sua maior proeminência como participantes focados.

Desse modo, o contraste observado entre construções diretas e indiretas em que a concordância de terceira pessoa plural varia dependendo da construção empregada constitui um comportamento gramatical sintomático da diferença em alinhamento de trajetor e marco.

Como apontado em capítulos anteriores, em construções diretas, a tendência é o verbo concordar com o argumento nominativo no plural - cf. o exemplo (18) da seção 4.1. em que ambos argumentos, tanto o nominativo quanto o dativo, estão no plural e a concordância se dá com o nominal nominativo na construção direta e, na construção indireta, com o nominal dativo -, enquanto na construção indireta, a tendência é a concordância em plural com o argumento dativo. 
Argumenta-se, portanto, que essa diferença em padrões de concordância é sintomática do alinhamento de trajetor e marco, isto é, a tendência é haver concordância de plural com o argumento mais saliente, o trajetor (foco primário).

Os verbos direto-indiretos exemplificados em (13) e (14) na seção 3.2 ilustram essa tendência. Como Aronson (1999) discute, quando o foco de interesse recai no argumento dativo em (13), o verbo concorda em plural com ele, quando, no entanto, o foco de interesse está no argumento nominativo, a concordância ocorre com o sujeito no nominativo, mesmo o argumento dativo sendo animado e plural. Essa diferença, acreditase, é resultado de atribuições de saliência a elementos distintos, em (13), o trajetor é o argumento dativo, em (14), é o argumento nominativo. Em ambas, a concordância é sintomática desse alinhamento.

Como foi discutido ainda na seção 3.2, nem sempre a concordância no georgiano seguiu essa tendência observada. No georgiano antigo, como exemplificado pelos exemplos retirados de Tuite (1998) em (10) em comparação a (11), a concordância se dava invariavelmente com o argumento no nominativo e não com o argumento dativo como no georgiano moderno. Dados como esse mostram-nos que possivelmente o argumento dativo, principalmente em verbos de Classe IV, foi ganhando maior saliência conceitual, i.e., de foco secundário passou a receber foco primário, e devido a essa mudança de saliência, começou a atrair a concordância de plural, tornando-se gramaticalmente mais ativo relativamente ao argumento nominativo.

Nas palavras de Langacker (2008), maior proeminência conceitual tem como consequência maior acessibilidade gramatical:

\footnotetext{
It stands to reason that the conceptual prominence would translate into grammatical "accessibility". The special grammatical behaviors of subject and object can thus be seen as symptoms of their referents being focused relational participants.
}

Dessa forma, comportamentos gramaticais, como concordância, surgem como forma de explorar ou sinalizar a saliência de certos participantes (LANGACKER, 2008).

\subsubsection{Verbos indireto-causativos.}


Análise similar à que temos discutido até agora para os verbos direto-indiretos também pode ser estendida aos verbos causativos-indiretos abordados na seção 4.2.

Como visto, os verbos chamados aqui de indireto-causativos têm, com exceção do segundo grupo como dividido por Tuite (2009), uma morfologia causativa. O primeiro grupo de verbos, exemplos de (24) a (27) da seção 4.2, pode aparecer tanto em seu uso bivalente, i.e., com o agente da causativa, quanto em seu uso monovalente, sem o agente. O uso bivalente, apresentando o agente, ocorre na construção direta (observe a marcação de caso em (27)), aproximando-se do significado da categoria de construções diretas, já que pressupõe um participante que é responsável pela ação. Ainda assim, a construção é uma extensão desse significado que pressupõe, prototipicamente, agentividade e volicionalidade por parte do agente, no caso da construção bivalente em (24) e (27), o sujeito (e foco primário) responsável pela ação é inanimado, correspondendo a sensações como medo.

O uso monovalente não só desse primeiro grupo, como dos outros dois, ocorre, em contraste, na construção indireta, havendo a omissão do agente da causativa. Possivelmente em razão de sua semântica - típica dos sentidos associados a verbos indiretos de Classe IV com sujeitos experienciadores, i.e., denotando, no caso desses verbos indireto-causativos, sensações corporais, dores e desconforto muscular, emanações corporais provocadas por estímulos internos corporais, etc, semântica, aliás, que pressupõe pouco ou nenhum controle e volição por parte do argumento dativo -, esses grupos de verbos passaram a ser aproximados ao esquema construcional, bastante arraigado e convencionalizado na língua, da construção com verbos de Classe IV, construção prototípica da categoria das construções indiretas, consistindo, dessa forma, em uma provável extensão desse protótipo.

De forma similar ao que vimos em relação aos verbos direto-indiretos, particularmente em relação ao terceiro grupo de verbos indireto-causativos, é que a partir da construção indireta (podendo ser considerada mais 'prototípica' devido justamente à semântica associada a esse grupo), há ainda uma extensão do uso desses verbos na construção direta, acarretando, em contraste, eventos em que o sujeito passa a ter controle sobre a situação, i.e., pressupondo que o evento é feito intencionalmente, de propósito (cf. exemplo na seção 4.2 em (29a') e (30a')).

Esse movimento, em que se observa a mudança e flexibilidade na construção de significado nesses grupos de verbos, mostra-nos como o significado das expressões não 
é algo fixo e estático, mas sim um processo dinâmico de conceitualização que está sujeito ao impulso dos falantes - e liberdade, como sujeitos conceitualizadores - em atribuir diferentes significados, formas distintas de se construir eventos e situações, utilizando os mecanismos ou estruturas disponibilizados pela própria língua.

Ademais, juntamente com o uso desses verbos causativos em construções indiretas, devido provavelmente à semântica típica dos eventos denotados por esses verbos, parece-nos que houve, consequentemente, uma mudança em termos de proeminência dos participantes envolvidos, o argumento dativo passando a receber maior proeminência, i.e., ganhando foco primário. Possivelmente, a mudança de foco primário para o argumento dativo foi propiciada pela omissão do agente que, conceitualmente, já não seria um participante necessário codificar devido à natureza dos eventos codificados por alguns desses verbos, perdendo saliência conceitual.

Dados como esses, assim como os vistos anteriormente nesta seção, reforçam a ideia de que a estrutura e semântica acarretada por construções indiretas, principalmente, com verbos de Classe IV, representam uma tendência na língua. Uma forma de se codificar certas significações de certa forma na língua. O mesmo é válido para outros casos, como aquele representado pelas construções diretas, tendo como representativas construções com verbos prototípicos de Classe I. Construções menos produtivas ou numerosas - como aquelas representadas por verbos direto-indiretos vistos aqui ou mesmo os verbos depacientivos que veremos adiante -, consistiriam, por sua vez, em tendências menos produtivas e salientes na língua, ainda sim significativas, já que também nos fornecem indícios de como os falantes atribuem significado, mostrando-nos como diferentes eventos e situações são conceitualizados por meio da língua e de sua estrutura.

\subsubsection{Contraste semântico e a importância da categoria semântica de volição em georgiano.}

Como foi visto nas seções anteriores, certos agrupamentos de construções coalescem ao redor de construções que consideramos como prototípicas na língua, representando tendências ou padrões plenamente arraigados e convencionalizados e 
passíveis de serem usados para a sanção de novas expressões. Atentou-se para dois desses agrupamentos ou categorias, as construções diretas e construções indiretas, cada qual com suas construções mais prototípicas.

Em cada caso, tanto em relação às construções diretas quanto indiretas, observase uma tendência de certos conjuntos de verbos de ocorrerem prototipicamente em uma ou em outra. Como foi salientado, lexemas verbais e os sentidos associados a eles são aprendidos no contexto das construções em que aparecem e vice-versa.

Dessa forma, o fato de um verbo aparecer repetida e convencionalmente em, por exemplo, uma construção indireta, o faz ter de maneira mais arraigada o sentido associado àquela construção, assim, um verbo indireto prototípico como $u$-qvar-s 'amar' carrega fortemente o sentido de não volicionalidade característico dessas construções. Similarmente, o sentido de não volicionalidade canônico das construções indiretas é também resultado dos verbos que prototípica e convencionalmente nelas ocorrem.

Com isso em mente, é possível dizer que certos eventos, denotados pelos verbos, têm uma forma mais prototípica ou canônica de serem conceitualizados pelos falantes na língua, sendo codificados de maneira particular, i.e., através de uma ou de outra construção. Apesar dessa prototipicidade, essa forma de se conceitualizar não é algo objetivamente discernível no mundo ou nos eventos em si, mas sim constitui uma maneira de se perceber ou construir eventos por parte dos falantes, i.e., depende da escolha do falante como sujeito conceitualizador, sendo uma questão de construal.

E as expressões discutidas nas seções anteriores, e mesmo nas seções seguintes, são um exemplo dessa escolha, da liberdade e impulso do falante em construir significado. Essa flexibilidade conceitual pode ser verificada na medida em que certos verbos, por vezes denotando o mesmo conteúdo conceitual, podem aparecer tanto em construções diretas quanto indiretas, variando em significado a depender da situação.

Mesmo verbos usualmente usados em construção diretas, como atos volitivos que pressupõem certo controle por parte do agente - e vice-versa, verbos prototipicamente indiretos que acarretam a noção de não volicionalidade - são empregados de forma contrária do usual, constituindo maneiras diferentes de se construir o mesmo evento.

Um elemento conceitual que parece ser fundamental para a diferenciação dessas duas categorias de construções é a volicionalidade do trajetor, acarretando certo controle, vontade ou intenção por parte do foco primário. Em muitos casos, essa noção conceitual é distintiva na caracterização da significação observada no uso de verbos, a priori, com 
o mesmo conteúdo conceitual. E os exemplos que foram discutidos até o momento são casos em questão. Como foi argumentado, acredita-se que essa noção conceitual esteja presente de forma esquemática na caracterização conceitual de cada categoria de construções de forma contrastiva, fazendo parte do construal imposto por cada construção.

Nesta seção veremos mais exemplos de expressões que se opõem na língua através da noção conceitual de volição, atestando para sua importância na construção de significado na língua e seu consequente reflexo nas formas linguísticas que a codificam.

Essa saliência conceitual da noção de volição, e a flexibilidade de eventos em serem construídos como atos volitivos ou não volitivos, não só é observável em georgiano, mas também em outras línguas como, por exemplo, a língua norte-caucasiana batsbi (ou tsova-tush) que codifica a diferença através de marcas formais.

Em batsbi, há o que Holisky (1987) chama de 'marcação variável' ou o que Dixon (1994) classifica como marcação de $S$ fluida, em que um único verbo intransitivo pode ter seu sujeito de primeira ou segunda pessoa marcado tanto com o caso ergativo quanto com o caso nominativo.

A variação em marcação reflete o grau de volição e controle por parte do sujeito, enquanto o verbo intransitivo em as (erg.) wozhe 'eu caí' implica que a queda foi intencional ou que foi causada por culpa do sujeito, o mesmo verbo com o sujeito no nominativo so (nom.) wozhe 'eu caí' não implica intencionalidade ou culpa por parte do sujeito (HOLISKY, 1987).

Segundo o estudo de Holisky (1987), dentre o grupo de verbos transitivos na língua que apresenta marcação variável, alguns ocorrem livremente em cada marcação a depender do contexto, como o verbo 'cair' citado acima, já outros mostram uma preferência por uma ou outra marcação, sendo a variação uma opção mais marcada, usada em raros ou excepcionais casos. Com verbos como 'morrer' e 'queimar', por exemplo, o uso do nominativo é o usual, não marcado, enquanto o uso do ergativo é raro, passando a interpretação de que o sujeito quer intencionalmente morrer ou ser queimado (uso que, segundo a autora, o informante relutou em aceitar, já que, para ele, ninguém intencionalmente vai querer morrer).

Essa variação em marcação reflete diferentes construals de eventos, apontando mais uma vez para o fato de que os eventos e o mundo não são objetivamente dados ao falante, e sim, sua construção está sujeita à forma como o falante não só percebe e 
apreende aquela situação, mas também a maneira como ele quer construir determinado evento. No caso de batsbi, a marcação formal de caso codifica construals distintos de um mesmo evento, em que a distinção entre atos volitivos ou não volitivos é contrastiva.

Em georgiano - em comparação à língua batsbi -, embora não haja formas sistemáticas que marquem distintivamente a noção de volição na língua, há, como vimos, certas marcas ou estratégias que em conjunto podem ser características ou indicativas de cada construção (diretas e indiretas), como, por exemplo, a concordância de plural com o nome, escolha dos afixos de concordância no verbo e marcação de caso.

Nos exemplos a seguir, com exceção de (54), os verbos contrastados pertencem morfologicamente a classes diferentes; os verbos chamados tradicionalmente de Classe I aparecendo em construções diretas, e os classificados como de Classe II em construções indiretas.

(50) Verbo de Classe I em (a) e verbo indireto de Classe II em (a'), e contraste entre os dois em (b).

a. ga-m-i-t'ex-a PV-1BDAT.SG-VPR-quebrar-3ANOM.SG.AOR.INDIC man me is Ele quebrou isso para mim.

a'. ga-m-i-t'qd-a is $\quad$ me PV-1BDAT.SG-VPR-quebrar-3ANOM.SG.AOR.INDIC 3SG.NOM 1SG.DAT $\mathrm{Eu}$ (dat.) quebrei isso.

b. ch'ika k'i ar ga-v-t'ex-e, ucabedad vidro.NOM apenas não PV-1AERG.SG-quebrar- AOR.INDIC de repente ga-m-i-t'qd-a PV-1BDAT.SG-VPR-quebrar-3ANOM.SG.AOR.INDIC

Eu não apenas quebrei o vidro, eu (dat.) de repente o quebrei.

[Adaptados de Asatiani (1998)]

(51) Verbo de Classe I em (a'), (b'), (c') e verbo indireto de Classe II em (a), (b), (c) e (e) e contraste entre os dois em (d). 
a. dzalian bevri pul-i da-m-e-xarj-a muito muito dinheiro-NOM PV-1BDAT.SG-VPR-gastar-3ANOM.SG.AOR.INDIC Eu fiquei sem dinheiro (apesar de minha vontade, eu não tive intenção).

a'. bevri pul-i da-v-xarj-e muito dinheiro-NOM PV-1AERG.SG-gastar-AOR.INDIC $\mathrm{Eu}$ gastei muito dinheiro.

b. bavshv-s v-a-seirn-eb-d-i da criança-DAT 1ANOM.SG-VPR-levar.para.passear-ST-SA-SM e c'a-m-e-kc-a PV-1BDAT.SG-VPR-cair-3ANOM.SG.AOR.INDIC

Eu levei a criança para passear e a deixei cair (de forma inesperada, apesar de minha vontade).

b'. chemi brali-a, bavshv-i me c'a-v-a-kci-e minha culpa-COP criança-NOM 1SG.ERG PV-1AERG.SG-VPR-cair-AOR.INDIC É minha culpa, eu derrubei a criança.

c. me shemo-m-a-k'vd-a 1SG.DAT PV-1BDAT.SG-VPR-matar-3ANOM.SG.AOR.INDIC Eu matei (aconteceu, eu não tive intenção).

c'. me mo-v-k'al-i 1SG.ERG PV-1AERG.SG-matar-AOR.INDIC Eu matei (eu planejei e matei).

d. k'i ar ga-v-lax-e, shemo-m-e-lax-a apenas não PV-1AERG.SG-bater-AOR.INDIC PV-1BDAT.SG-VPR-bater-3ANOM.SG.AOR.INDIC Eu não apenas bati, eu (dat.) bati nele sem ter intenção.

[Adaptados de Asatiani (1998)]

e. me shemo-m-e-landzgh-a chem- $\mathrm{i}$

1SG.DAT PV-1BDAT.SG-VPR-insultar-3ANOM.SG.AOR.INDIC 1POSS.SG-NOM tav-i mesmo-NOM

Eu insultei a mim mesmo sem intenção. [Adaptado de Amiridze (2006)] 
(52) Verbo de Classe I em (b) e verbo indireto de Classe II em (b'), e contraste entre os dois em (a).

a. k'i ar she-v-cham-e, shemo-m-e-cham-a apenas não PV-1AERG.SG-comer-AOR.INDIC PV-1BDAT.SG-VPR-comer3ANOM.SG.AOR.INDIC

Eu não apenas comi, eu comi sem ter intenção, sem querer. [Adaptado de Asatiani (1998)]

b. bavshv-eb-i cham-en vashl-eb-s

criança-PL-NOM comer-3ANOM.PL maça-PL-DAT

As crianças estão comendo maças.

b'. bavshv-eb-s e-chmev-a-t vashl-eb-i

crianças-PL-NOM VPR-comer-3ANOM-PL.DAT maça-PL-NOM

As crianças estão comendo maças (e.g., apesar de as crianças não terem permissão para comer as maças, não puderam resistir e estão comendo mesmo assim).

(53) Verbo de Classe I em (a) e (b) e verbo indireto de Classe II em (a') e (b').

a. me c'amo-m-cd-a

1SG.DAT PV-1BDAT.SG-dizer-3ANOM.SG.AOR.INDIC

Eu disse (eu não queria dizer, escapou).

a'. me v-tkv-i

1SG.ERG 1AERG.SG-dizer-AOR.INDIC

Eu disse (eu tinha uma razão para dizer algo).

b. mas a-e-ri-a saxel-eb-i

3SG.DAT PV-VPR-confundir-3ANOM.AOR.INDIC nome-PL-NOM

Ele confundiu os nomes (não tinha a intenção).

b'. man a-u-ri-a saxel-eb-i

3SG.ERG PV-VPR-confundir-3ANOM.AOR.INDIC nome-PL-NOM

Ele confundiu os nomes (intencionalmente).

(54) Verbos de Classe III e oscilação na marcação de caso. 

a. macivr-i-dan c'q'al-ma i-c'vet-a
geladeira-INST-POSP água-ERG VPR-pingar-3A.SG.AOR.INDIC
A água pingou da geladeira.
b. macivr-i-dan c'q'al-i i-c'vet-a
geladeira-INST-POSP água-NOM VPR-pingar-3ANOM.SG.AOR.INDIC
A água pingou da geladeira.

[Adaptados de Harris (1981)]

A diferença de significação entre as construções contrastadas gira em torno, principalmente, da volicionalidade do trajetor ou foco primário.

As expressões em (50a) e (50a'), ambas nas Séries II do Aoristo, semanticamente se distinguem em termos de volição ou intencionalidade do trajetor em praticar a ação, a diferença sendo melhor observada em (50b). Em (50a), e similarmente na primeira oração em (50b), o trajetor man 'ele' é o agente que, em uma cadeia de ação, intencionalmente causa a mudança de estado no tema, o marco ou foco secundário, is ‘ele/isso' em benefício do participante $m e$ 'eu'.

Essa organização conceitual é refletida linguisticamente na concordância e na marcação de caso, sendo esta última característica de verbos de morfologia de Classe I nas Séries II, o sujeito é marcado com o caso ergativo, o objeto direto com o caso nominativo e o objeto indireto com o caso dativo. Em (50a'), o conjunto de afixos B concorda com o objeto indireto, em sua ausência, o afixo de primeira pessoa do conjunto A apareceria em seu lugar e concordaria com o sujeito, assim como ocorre na primeira oração em (50b), não podendo as duas marcas ocorrerem ao mesmo tempo no slot 2.

Em (50a') e na segunda oração em (50b), a ação é não volitiva ou intencional, o trajetor é o argumento no dativo $m e$ 'eu', concordando com o verbo e que causa a mudança de estado no tema e foco secundário is 'ele/isso'. Tanto em (50a') quanto na segunda oração de (50b), a interpretação passada é a de que a ação aconteceu de forma não intencional ou mesmo acidental, sem que o sujeito tivesse controle.

O mesmo ocorre nos contrastes em (51). Em (51a', 51b', 51c') e na primeira oração em (51d), são todos eventos no aoristo que denotam um ato volitivo e intencional por parte do trajetor, marcado pelo caso ergativo e que concorda no verbo através do afixo de primeira pessoa $v$ - do conjunto A. Em contrapartida, os exemplos em (51a, 51b, 51c, 
51e) e na segunda oração em (51d) denotam eventos também no aoristo em que o trajetor, no caso dativo e concordando no verbo através do afixo $m$ - do conjunto $\mathrm{B}$, tem pouco ou nenhum controle ou volição sobre a ação praticada.

Em (52), temos mais um contraste entre dois eventos que se distinguem pela volicionalidade ou intencionalidade do trajetor. Em (52a), há o verbo contrastado no aoristo; na primeira oração, a ação é intencional, o trajetor é marcado pelo caso ergativo e concorda no verbo através do afixo do conjunto A v-, na segunda oração, a ação é feita sem intenção e o trajetor é marcado com o caso dativo, concordando no verbo por meio do afixo $m$ - do conjunto B. Em (52b e b'), a mesma oposição é verificada, nesses casos, as sentenças estão no presente e têm seu argumento no plural. Na construção direta em (52b), o verbo concorda, através do afixo -en, com o argumento no plural bavshv-eb-i 'as crianças' que está no caso nominativo e que constitui o foco primário. Na construção indireta em (52b'), o verbo passa a concordar com o argumento dativo no plural e foco primário, bavshv-eb-s 'as crianças', através do afixo de plural - $t$.

Em (53), o contraste é semelhante, em (53a' e 53b'), os eventos no aoristo se referem a uma ação volitiva e intencional por parte do foco primário, estando no caso ergativo e sendo marcado no verbo, em (53a'), através do afixo $v$ - do conjunto A. Em (53a e 53b), os eventos, também no aoristo, remetem a uma ação não intencional praticada pelo trajetor no caso dativo e marcado no verbo, em (53a), por meio do afixo $m$ - do conjunto B.

Como pode ser visto por mais esses exemplos descritos, os padrões evidenciados por construções diretas e indiretas representam tendências arraigadas na língua, distinguidas principalmente pela noção conceitual de volição, o que atesta para sua importância no processo de conceitualização acionado por essas construções. E ainda que essa categoria semântica não seja codificada por meio de uma marcação particular como em batsbi, certas estratégias são empregadas em georgiano para codificar essa concepção, i.e., sua presença parece estar fortemente arraigada em alguns padrões na língua, a exemplo dos padrões que vimos nessas construções em termos de forma, principalmente em relação a padrões de concordância e marcação de caso.

Os exemplos em (54) servem para atestar não só para a observação de como certos padrões na língua têm a noção de volição como um importe semântico fortemente arraigado, mas também para mostrar como essa noção está presente na construção e 
conceitualização de eventos tal como são percebidos e apreendidos pelo falante como sujeito conceitualizador, nesse ponto, de forma similar ao caso de batsbi.

O verbo em (54) apresenta marcação variável; enquanto a sentença em (54a) constitui o padrão considerado normativo, i.e., o verbo classificado como de Classe III tem o sujeito marcado com o caso ergativo no aoristo, em (54b), temos o uso coloquial em que o sujeito é marcado com o caso nominativo. Interessantemente, segundo Harris (1981), ao ter apresentado as duas sentenças variantes a um falante, este lhe respondeu que embora soubesse que a sentença em (54a) seria a 'correta', soava-lhe estranha, parecendo que a água estava pingando de propósito.

A intuição do falante parece apontar não só para o evidente arraigamento da noção de volição, em particular, ao padrão com o caso ergativo no aoristo (como, inclusive, visto nos exemplos discutidos acima), mas também para a forma como o falante apreende e conceitualiza determinados eventos e os constrói por meio das ferramentas que sua própria língua disponibiliza, a exemplo dos verbos direto-indiretos e sua variação.

Ademais, como demonstram línguas como o georgiano e batsbi, a noção conceitual de volição parece ser um elemento essencial na conceitualização de eventos. Acredita-se que, devido à sua saliência cognitiva, essa noção possa, inclusive, constituir um arquétipo conceitual em si nos termos da CG.

Arquétipos conceituais são conceitos aterrados em nossa experiência como a noção de um objeto físico, um objeto se movendo, o ato de segurar alguma coisa, passar alguma coisa, etc. (LANGACKER, 2008).

Ainda que a noção de volição ou de controle faça parte de outros arquétipos conceituais da nossa experiência, a noção em si parece ainda mais fundamental na medida em que está ligada essencialmente à forma como interagimos com o mundo desde muito cedo e nossa percepção sobre ele. Nesse mundo experienciado, exercemos controle sobre certos objetos e atos, sobre o ambiente ao nosso redor, como andar e correr, ações que usualmente percebemos como um ato volitivo que está sob nosso poder controlar, assim como experienciamos situações que estão além de nosso controle ou vontade, em que estamos sujeitos a certas ações que não podemos exercer força ou controle como ao sentir certas emoções ou tropeçar e cair.

A noção conceitual de volição parece emergir desse nosso contato experiencial com o mundo, sendo codificada na língua por meios diversos, não restringindo-se, no 
entanto, por esse mundo ou uma realidade objetiva, já que sua codificação depende da conceitualização que fazemos desses eventos, da forma como os construímos.

\subsection{Verbos depoentes.}

\subsubsection{Vogal pré-radical e verbos comitativos.}

Como exposto na seção 3.3, a vogal pré-radical -i-, em sua função de versão verbal, marca a adição de um argumento extra à estrutura verbal. Nessa função, especificamente, a versão verbal em georgiano se assemelha ao que chamam de aplicativos. Nos termos da CG, um aplicativo tem a função de fazer de um sintagma nominal um participante focado, especificando-o não perifrasticamente (LANGACKER, 2008). Diferente do uso de uma posposição - opção disponível em substituição às versões em georgiano - que introduz um nominal perifrasticamente por meio de uma relação codificada separadamente, indicando que o envolvimento daquele nominal é mais periférico. De acordo com Langacker (2008), a posposição (ou preposição em outras línguas) perfila uma relação que se dá entre o processo designado (seu trajetor) e um participante presente nele (seu marco).

Por essa perspectiva, a versão verbal marca uma relação mais intrínseca ao verbo, inclusive estando morfologicamente mais próxima à raiz verbal. Diferentemente de um objeto indireto marcado somente com o caso dativo em georgiano - mais básico e por isso menos marcado em comparação à versão - o objeto indireto referenciado pela versão é menos básico, sendo explicitamente marcado na estrutura verbal através da versão que, assim, indica a presença de um participante focado adicional, dirigindo a atenção ao papel saliente daquele participante no evento.

Como indicativo de quanto esse tipo de significação envolvendo proeminência é difuso e arraigado na língua e também no próprio espectro de significados e funções associados à vogal pré-radical, podemos começar por discutir o caso dos verbos depoentes chamados de comitativos. 
Como visto na seção 4.4 a respeito dos verbos depoentes comitativos, eles têm como base os verbos lexicalmente recíprocos chamados tradicionalmente de Classe III. Além da diferença em relação ao número de argumentos - há um aumento de argumentos nos verbos comitativos -, os verbos comitativos apresentam a vogal pré-radical $-e$ marcando o argumento extra.

Foi argumentado que a mudança de morfologia está relacionada ao aumento de valência de um verbo para outro. A vogal pré-radical $-e$ - nesses verbos estaria funcionando como marca de comitatividade, isto é, como uma 'versão comitativa', tendo como função tornar aquele sintagma nominal comitativo um argumento da estrutura do verbo, enquanto verbos chamados de Classe III permaneceriam como opção para aparecerem em construções com sintagmas nominais posposicionados.

Devido ao forte arraigamento e difusão da construção envolvendo a vogal préradical em sua função de versão, fazendo de um sintagma nominal um argumento do verbo, i.e., fazendo daquele nominal um participante focado, é possível dizermos que a mudança de morfologia de uma classe à outra está associada à atribuição desse tipo de conceitualização, acionada pela construção com a versão na língua, à construção com sentido comitativo, para isso, derivando o sentido comitativo em verbos de morfologia de Classe II a partir de verbos lexicalmente recíprocos de Classe III.

Como pode ser observado através da exposição que foi feita do sistema verbal georgiano, a construção com verbos intransitivos de morfologia de Classe II, utilizando a vogal pré-radical - $e$ - para marcar a presença de um objeto indireto, é fortemente arraigada na língua, sendo possível supor que um esquema construcional, abstraído do uso repetido desse tipo de construção, tenha sido selecionado para ser usado na derivação de verbos comitativos a partir de verbos lexicalmente recíprocos de Classe III, o que explicaria a mudança de morfologia.

O esquema construcional contendo verbos chamados de Classe II em conjunto com a vogal pré-radical - $e$ - para marcar o objeto indireto teria funcionado como unidade atratora devido ao seu forte arraigamento, sendo explorada para dar o significado consequentemente arraigado nesse tipo de construção e no espectro de significados associados à vogal pré-radical -e-, i.e., a adição de um participante focado à estrutura nesse caso, o nominal comitativo seria o marco, tendo proeminência secundária -, tornando essa relação mais intrínseca ao verbo e, diferente do uso com posposição em verbos de Classe III, não perifrástica. 
Dessa forma, podemos dizer que o esquema construcional, apresentando usualmente verbos chamados de Classe II em conjunto com a vogal pré-radical - $e$-, foi estendido a verbos derivados com sentido comitativo, nesse caso, a vogal pré-radical - $e$ carregaria uma nova extensão, a de versão comitativa.

\subsubsection{Verbos depacientivos.}

\subsubsection{Voz gramatical}

A variedade observada nos fenômenos de voz encontrados nas línguas reflete a multiplicidade de estratégias que podem ser exploradas e usadas pelos falantes na conceitualização de eventos.

Woods (2008), em seu livro sobre os prefixos de conjugação do sumério, descreve voz gramatical e sua relação com os prefixos sumérios nos seguintes termos:

Broadly described, grammatical voice systems provide speakers with a series of linguistic options for expressing distinct conceptualizations of experience and reality. This is precisely the role played by the Sumerian conjugation prefixes: providing the Sumerian speaker with the linguistic means to express alternative perspectives on events (WOODS, 2008, p. 7).

Compartilhando essa visão, acredita-se que a construção que temos chamado aqui de depacientiva constitui, particularmente, uma estratégia de voz, i.e., constitui uma maneira de expressar uma conceitualização distinta dos eventos. Por essa perspectiva, a vogal pré-radical - $i$ - - a priori, apropriada de outras construções na língua - de forma semelhante aos prefixos do sumério, estaria servindo para codificar ou marcar linguisticamente a distinção em significação.

Antes de adentrarmos nessa discussão - a construção depacientiva e sua relação com a noção de voz gramatical como maneira de se conceitualizar eventos de formas alternativas e, assim sendo, sua relação com construções circundantes também envolvendo voz -, serão apresentados alguns conceitos provenientes da CG e que serão relevantes para a discussão. 


\subsubsection{Arquétipos conceituais na CG e estratégias de codificação.}

Na CG, como mencionado na seção 5.3, classes gramaticais, como verbo e substantivo, são definidas conceitualmente, tanto a nível de protótipo quando a nível de uma caracterização esquemática comum, estendida a todos membros da categoria.

Para o verbo, o protótipo da categoria - um arquétipo conceitual aterrado em nossa experiência e suficientemente saliente para induzir que uma classe gramatical forme-se ao seu redor - seria a concepção de participantes interagindo energeticamente em um evento de dinâmica de forças (LANGACKER, 2008).

A caracterização esquemática envolveria habilidades cognitivas básicas manifestadas, de início, no arquétipo conceitual e depois estendidas a outros membros, sendo válida para todas as instâncias. Para o verbo, essas habilidades seriam nossa capacidade de apreender relações e rastrear essas relações ao longo do tempo.

Tanto o arquétipo conceitual do verbo quanto do substantivo - a concepção de um objeto físico - fazem parte do que na CG chama-se de modelo da bola de bilhar, envolvendo a concepção de objetos discretos movimentando-se e interagindo uns com os outros energeticamente. Uma série dessas interações, havendo em cada uma transmissão de energia de um participante a outro, é chamada de cadeia de ação.

Esses arquétipos estão envolvidos no 'modelo de evento canônico', representando a forma mais canônica de ocorrência, i.e., um evento energético em que um agente age sobre um paciente para induzir uma mudança de estado (uma cadeia de ação envolvendo transmissão de energia de um participante a outro). Nesse modelo, o evento é concebido como se observado de um ponto de vista externo por um observador (o chamado stage model), sendo, esse evento, o foco de atenção.

A forma mais típica de se codificar linguisticamente esse tipo de evento canônico é através de uma construção transitiva, em que a interação entre agente e paciente é perfilada e colocada onstage, o agente constituindo o foco primário e o paciente o foco secundário. Nesse tipo de codificação default, os elementos da sentença adquirem seus valores prototípicos, i.e., um verbo prototípico é aquele que perfila uma interação entre 
agente e paciente, e o protótipo para o sujeito e o objeto são os arquétipos de agente e paciente respectivamente (LANGACKER, 2008).

Dessa forma, o protótipo de uma construção transitiva é o modelo de evento canônico. Transitividade, portanto, é uma noção conceitual, dependente de como a situação é construída, e uma questão de gradação, quanto maior o grau de aproximação de uma interação canônica entre agente e paciente, mais transitiva aquela construção, a princípio, será.

Essa, no entanto, não é a única estratégia de codificação presente nas línguas, nem a mais canônica a depender da língua. Langacker (2008) divisa, em particular, duas importantes orientações ou alinhamentos, orientação de agente e orientação de tema. Cada um desses alinhamentos reflete uma forma de dar proeminência linguística a um papel arquétipo de participante, nesses casos, de agente e tema (este último, abarcando, no uso do autor, os papéis de paciente, experienciador, zero, etc.).

Embora cada língua, de uma forma ou de outra, faça uso de ambos os alinhamentos em menor ou maior grau, tanto um alinhamento quanto o outro pode ser estabelecido em dada língua como a orientação default ou mais canônica (LANGACKER, 2008).

A orientação de agente é a estratégia de codificação que seleciona o agente como trajetor, i.e., como foco primário. Segundo o autor, essa estratégia reflete um aspecto básico da experiência humana em que agimos no mundo como criaturas conscientes e volitivas, transmitindo energia para mantermos e controlarmos o ambiente ao redor. Nas línguas em que é selecionada como alinhamento default, o tipo mais básico de sentença é a construção transitiva que codifica a situação descrita há pouco, i.e., uma interação canônica entre agente e paciente, em que o agente é escolhido como trajetor.

A orientação de tema, por sua vez, é a estratégia que seleciona o tema como trajetor. Assim como a orientação de agente, a orientação de tema também reflete um aspecto fundamental de nossa experiência, em que o mundo no qual operamos é posto de certa forma e onde entidades ocupam diferentes lugares e exibem propriedades distintas, sendo acessíveis e suscetíveis à nossa influência em diferentes graus (LANGACKER, 2008).

Nas línguas em que essa orientação é a default, o tipo mais básico de sentença é um processo temático envolvendo um único participante, o tema e, portanto, trajetor. 
Como nesse tipo de língua o tema recebe maior proeminência, em uma sentença com dois participantes transitiva, é o tema que é escolhido como trajetor (LANGACKER, 2008).

Um processo temático é aquele contendo apenas um participante, nesse caso, um tema, construído como passivo e não como fonte de energia (como o agente em uma cadeia de ação). Esse tipo de processo é construído de forma autônoma, sem evocar a fonte energia, representando nessa concepção o que se chama, na CG, de construal absoluto. Segundo o autor, enquanto um processo temático pode ser concebido de forma autônoma, i.e., sem evocar a fonte de energia, o contrário não ocorre, já que não se poderia conceitualizar um evento agentivo sem evocar, ainda que esquematicamente, a ocorrência por ele induzida; a noção de agência, em si, pressupondo a existência de um processo temático (LANGACKER, 2008).

Essas duas orientações, na CG, refletiriam dois caminhos naturais de acesso mental aos elementos de uma sentença complexa, um em que o ponto de início seria o agente no fluxo de energia de uma cadeia de ação, e o segundo, em que o ponto de início seria o processo temático, i.e., em um processo construído de forma autônoma. Esses dois caminhos naturais ainda podem alinhar com outros dois caminhos naturais, o de ordem de palavras e o de proeminência focal, i.e., partindo do trajetor, em seguida o marco e depois outros participantes. Cada uma dessas orientações, portanto, serviria como uma forma de alinhamento entre o ponto inicial do caminho natural de proeminência focal, o trajetor, e o ponto inicial de cada orientação; no caso do fluxo de energia, o agente; e no caso de um processo construído de forma autônoma, o processo temático.

\subsubsection{Construção depacientiva e construções circundantes}

Em línguas de orientação de agente, usualmente a voz ativa é tomada como o default, enquanto em línguas de orientação de tema a construção absoluta seria o default. As vozes conhecidas como passiva e antipassiva constituiriam alternativas para essa codificação default respectivamente, a passiva servindo para dar maior proeminência ao paciente e a antipassiva ao agente. Em relação ao default, essas alternativas de codificação normalmente são mais marcadas na língua, codificando linguisticamente uma estratégia distinta de se conceitualizar o evento. 
A priori, o georgiano parece ser uma língua híbrida, já que parece fazer uso de ambas formas de codificação, não sendo, no entanto, o intuito deste trabalho verificar qual orientação é mais proeminente ou não no atual estado da língua.

O que nos interessa aqui é discutir a construção depacientiva como forma alternativa de se construir eventos e sua relação com construções circundantes, como a construção transitiva, passiva e com alguns dos significados da voz média.

Em comparação com a construção passiva em georgiano, formada, como visto pela vogal pré-radical $-i-$, a construção ativa na língua pode ser considerada como a menos marcada. Por essa perspectiva, relativamente à construção ativa, a vogal pré-radical $-i$ estaria marcando, linguisticamente, uma alternativa distinta de codificação do evento.

A construção ativa ou voz ativa é aquela que seleciona o agente como o mais proeminente em uma interação entre agente e paciente, em que o evento é visto como uma cadeia de ação, envolvendo transmissão de energia entre agente e paciente de forma que este último sofre os efeitos da mudança induzida pelo agente. $\mathrm{O}$ agente, portanto, seria o ponto inicial de acesso mental do evento.

Essa estratégia de se conceitualizar o evento pode ser observada nos exemplos (33a') e (35b) com os verbos 'xingar' e 'morder', ambos envolvem a conceitualização de uma cadeia de ação em que há transmissão de energia entre agente e paciente, o agente é a fonte de energia dessa cadeia de ação e o primeiro elemento a ser acessado, constituindo o foco primário, nos exemplos, os nominais no nominativo 'ele' e 'criança'. O paciente, por sua vez - nos exemplos, os nominais no dativo 'governo' e 'me' - sofre a mudança imposta pelo agente, ainda que metafórica.

A figura abaixo ilustra o diagrama da construção transitiva. Observe que todo o processo é perfilado, do ponto inicial, o agente e foco primário (trajetor), ao fim, o paciente e foco secundário (marco).

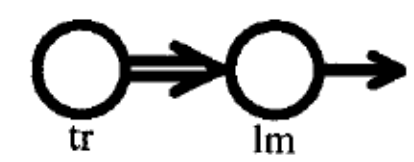

Figura 1: Construção transitiva ativa (LANGACKER, 2008, p.385)

Relativamente a essa codificação canônica, a construção passiva se destaca por oferecer um construal distinto do mesmo evento. Na construção passiva, o tema é escolhido como foco primário ou trajetor do processo. $\mathrm{O}$ agente do processo e fonte de 
energia é apenas uma entidade implícita ou pressuposta, podendo não ser codificado ou ser codificado perifrasticamente por meio de uma posposição.

Um exemplo de construção passiva no georgiano com a vogal pré-radical - $i$ - pode ser observado em (36c). Nesse exemplo, em particular, o verbo de Classe II está em sua forma relativa, i.e., na presença de um objeto indireto no dativo kal-s 'mulher', a vogal pré-radical - $i$ - nesse verbo foi substituída pela vogal pré-radical - $e$ - que marca a presença do argumento extra. De qualquer forma, a sentença exemplifica uma construção passiva típica na língua, em que o foco primário é deslocado para o tema pul-i 'dinheiro', omitindo-se o agente da ação do processo perfilado, ou seja, aquele que dá o dinheiro, a fonte de energia.

A figura a seguir representa o diagrama da construção passiva, em que apenas o tema recebe status de participante focado, constituindo o foco primário.

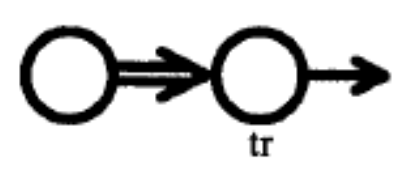

Figura 2: Construção passiva (LANGACKER, 2008, p.385)

Em contraste a essas duas vozes gramaticais, a função da voz média, segundo Maldonado (2007), estaria em focar no próprio domínio do sujeito, i.e., denotaria eventos ou estados pertencentes à própria esfera do sujeito. Mais especificamente, para o autor:

\footnotetext{
[The middle voice] core function is to focus on the change-of-state undergone by the subject (Maldonado 1992, 1999). In other words, since the middle marker imposes a conceptualization centered on the subject, it crucially profiles the observable change-of-state. (MALDONADO, 2007, p. 856).
}

Dentre os eventos prototípicos associados à voz média, estão os ‘tipos de situação' identificados por Kemmer (1994) como sendo aqueles usualmente marcados pela construção média, por exemplo: eventos de cuidados corporais, envolvendo elementos dentro do domínio do sujeito, tais como partes do corpo e posse inalienável; eventos de mudança de postura corporal do sujeito e mudança de lugar, acarretando alguma transmissão de energia interna; eventos envolvendo mudanças internas, mentais ou emocionais; etc (cf. MALDONADO, 2007). 
Nessas situações típicas da voz média, os efeitos da ação denotada pelo verbo recaem, de um modo ou de outro, sobre o próprio sujeito ou sobre seu domínio, por essa razão, o evento gira em torno daquele único participante. E como observa Maldonado (2007), a construção média frequentemente se sobrepõe às construções intransitivas, já que ambas envolveriam um participante. Esse dado é particularmente interessante se pensarmos que, no georgiano e em outras línguas (ver discussão da seção 4.5), a mesma marca morfológica parece codificar construções associadas à intransitividade, como construções passivas, médias e depacientivas. Em georgiano, notoriamente, a vogal préradical $-i-$.

Devido ao foco, na construção média, recair em seu único participante, haveria um maior grau de não distinguibilidade, ou não diferenciação, entre participantes, i.e., entre sujeito e objeto afetado. Por essa razão, Kemmer (1994) posiciona a voz média como estando entre eventos de dois participantes e de um participante, havendo uma diminuição gradual de distinção de participantes entre um ponto (dois participantes) a outro (um participante). Nesse aspecto, a construção reflexiva contrastaria com a construção média, já que, ao contrário da construção média em que não há diferenciação de participantes, o sentido reflexivo implicaria correferencialidade entre sujeito e objeto, i.e., um único participante ocuparia os papéis de trajetor e marco (LANGACKER, 2008; MALDONADO, 2007).

O diagrama a seguir, na Figura 3, representa a construção média, envolvendo um evento que ocorre dentro do domínio do próprio sujeito:

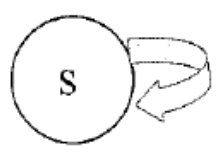

Figura 3: Construção média (MALDONADO, 2007)

Em georgiano, embora não haja uma construção específica que marque os significados usualmente associados à voz média, é interessante observarmos aqui algumas similaridades, já notadas na literatura da língua, entre os significados da voz média e, em específico, a versão subjetiva (marcada pela vogal pré-radical -i-).

Tuite (2007) aponta algumas semelhanças entre a descrição da semântica frequentemente atribuída à voz média àquela da versão subjetiva, como, por exemplo, a denotar eventos que acontecem em benefício do sujeito ou de sua posse. Em particular, 
alguns grupos de verbos - destacados pelo autor e formados pela vogal pré-radical - $i$ - ou, mais especificamente, pela versão subjetiva - corresponderiam a alguns dos significados relacionados à construção média. ${ }^{12}$

Dentre eles, estão certos verbos ativos que teriam a versão subjetiva como formação não marcada, i.e., não teriam formas correspondentes com a versão neutra ou objetiva. Segundo Tuite (2007), esses verbos teriam uma semântica consistente, em que a ação denotada pelo verbo seria orientada para o sujeito, a maior parte aglomerando-se ao redor das situações de tipo descritas por Kemmer (1994) como 'média indireta', por exemplo, o verbo $v$-i-dzen 'eu procuro, obtenho' e 'média cognitivas', por exemplo, o verbo $g a-v-i-g e b$ 'eu entenderei' (TUITE, 2007).

Outros verbos seriam certos verbos ativos com a versão subjetiva como, por exemplo, $v$-i-p'ars-av 'eu me barbeio' correspondendo à situação de tipo de Kemmer (1994) referente a cuidados corporais; e uma parte considerável de verbos tradicionalmente classificados como de Classe III como, por exemplo, $v$ - $x t$ 'una-ob 'eu pulo para cima e para baixo' (fut: v-i-xt'unav-eb) correspondendo à situação de tipo de 'movimento translacional' de Kemmer e v-c'k'mut'un-eb 'eu choramingo' (fut: $v-i$ c'k'mut'un-eb) correspondendo à situação de 'ações de fala emotiva' (TUITE, 2007).

No georgiano moderno, a vogal pré-radical $-i$ - apenas está presente nas formas do futuro e do aoristo de verbos de Classe III, seu aparecimento, nesses tempos, sendo um desenvolvimento posterior a partir de empréstimo de outros paradigmas verbais télicos, o que parece também ter motivado a maior sobreposição da versão subjetiva nesses verbos de Classe III com a voz média (TUITE, 2007).

Diante dessas considerações, é possível perceber que, ainda que o georgiano não possua uma construção específica que marque a voz média, há correlações e similaridades entre os significados usualmente atribuídos à voz média e o uso da vogal pré-radical - $i$ Mais notavelmente, e o ponto a ser argumentado a seguir, é que a mesma marca em georgiano, associada aos significados da voz média, venha a marcar também a construção depacientiva sob foco.

Essa correlação entre a marcação das duas construções não é exclusiva do georgiano. Como notado na seção 4.5, na língua to'aba'ita, a mesma marca encontrada na construção depacientiva também é observada em construções com significados

\footnotetext{
12 Tuite (2007) atenta, por exemplo, para a similaridade semântica entre o verbo ativo com versão subjetiva $i$-xsn-i-s 'soltar, desatar' e o verbo na voz média do grego $\lambda \hat{v} \varepsilon-\tau \alpha \iota$ 'soltar, desatar para si mesmo'.
} 
atribuídos à voz média. Mais do que mera coincidência, acreditamos que a correlação em marcação entre as duas construções se dá por certas similaridades conceituais entre os diferentes construals por elas codificados.

As construções ativas transitivas em (33a') e (35b) que, como discutimos, codificam o modelo de evento canônico - i.e., uma interação entre agente e paciente, em que o primeiro induz uma mudança de estado no segundo -, se tomadas como a construção não marcada relativamente, por exemplo, à construção passiva, podem ser consideradas como a base para a derivação também de construções como a depacientiva, mais marcada, tanto em termos de significado, já que, acredita-se, constitui uma alternativa de se conceitualizar esse evento canônico, quanto em termos de forma, i.e., no uso da vogal pré-radical $-i$ -

Nos exemplos de construções depacientivas fornecidos na seção 4.3, (33a), (34), (35a, 35a'), (38) e (39), há, nos verbos de base transitiva (aqueles chamados de Tipo 2 por Tuite (2002)), o apagamento do paciente relativamente à construção equivalente transitiva. Observe que tanto em (33a) e (35a e a') - em contraste com (33a') e (35b) respectivamente - como (34a, 34d, 34e), o tema, constituindo o foco secundário, o marco, é apagado: a entidade à qual é dirigido o xingamento em (33a), o olhar em (34d) ou o ato de bater em (34a), quem ou o que é mordido em (35a e 35a') ou mastigado em (34e) - cf. o verbo transitivo coxn-i-s 'mastigar', usualmente usado para designar o ato de mastigar de animais ruminantes com um objeto direto indicando o que é mastigado, como grama, etc. (TUITE, 2002).

O resultado são eventos de um argumento que, sendo o único participante focado, passa, consequentemente, a receber proeminência máxima, i.e., é o foco primário, o trajetor. Como ressalta Langacker (2008), a própria ausência de um argumento já resulta em uma maior saliência do participante restante, visto que se anula a competição entre participantes.

Mesmo em verbos normalmente usados intransitivamente como (34b e 34d), (38) e (39), o efeito ou resultado do seu uso na construção depacientiva é o mesmo de verbos de base transitiva, o único participante recebe proeminência máxima, denotando um evento muito mais marcado semanticamente do que o correspondente intransitivo ativo, semanticamente menos marcado (cf. a-purtx-eb-s 'cuspir', q'ep-s 'latir' e p'ranch'-av-s 'fazer graça, flertar'). 
Como consequência, a construção depacientiva em todos esses exemplos, (33a), (34), (35a, 35a'), (38) e (39), tem como efeito, em contraste com a construção ativa, deslocar o foco para os contornos da ação denotada pelo verbo e para o sujeito como agente daquela ação. Essa mudança de foco acarreta eventos semanticamente mais marcados, i.e., há uma maior caracterização desse evento em termos de sua aparência ou impressão causada nos outros, ou seja, tal como é percebido pelo observador, sendo orações usualmente proferidas na segunda e terceira pessoas.

Por essa razão, essas construções não raramente apontam para o comportamento inapropriado, desagradável ou inconveniente do sujeito, ocasionando uma impressão negativa por parte do observador. Ademais, frequentemente enfatizam a natureza repetitiva ou habitual de certas ações, às vezes como ações características do sujeito - por exemplo, o verbo depacientivo de Tipo II em (34e) e (35a e a') e de Tipo III em (38), denotando eventos de natureza repetitiva ou que são característicos daquele sujeito, i.e., como a possuir aquela propriedade (TUITE, 2002).

Devido ao foco estar na natureza da ação e no próprio agente que a pratica, os eventos comumente denotados nessas construções referem-se, segundo Tuite (2002), a comportamentos que chamam a atenção do observador por sua aparência ou conveniência, abarcando verbos que expressam ações comportamentais como comer (e.g., $i$-coxn-eb-a 'mastigar'), olhar (i-ch'qit'-eb- $a$ 'olhar estupefato'), contato corporal (i-k'bin-eb-a 'morder'), expressões faciais (i-ghmich'-eb-a 'contorcer a face em desagrado'), atitudes ou comportamentos (i-p'ranch'-eb-a 'fazer graça, flertar'), atos de fala (i-landzgh-eb-a 'insultar'), etc. (TUITE, 2002).

Devido a essa saliência atribuída ao agente, ele constituiria o ponto de início de acesso mental tanto do ponto de vista de proeminência, como trajetor, quanto da orientação considerando o fluxo de energia numa cadeia de ação, como agente. Da mesma forma que na construção ativa, o evento é evocado como uma cadeia de ação, envolvendo transmissão de energia entre agente e um tema. No entanto, diferentemente da construção ativa que perfila todo o evento, de seu início da cadeia de ação, o agente, ao seu resultado, o processo temático, a construção depacientiva evoca o processo temático apenas de forma esquemática (observe Figura 4), não constituindo um participante focado, i.e., não é codificado linguisticamente. Na construção depacientiva, apenas o início da cadeia de ação é perfilado e codificado, ou seja, o agente e a ação por ele praticada. 


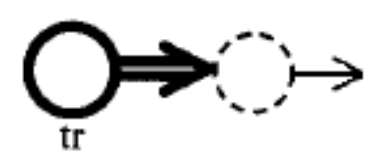

Figura 4: Construção depacientiva

Desse modo, acredita-se que a construção depacientiva constitui uma alternativa de conceitualização de eventos relativamente à construção ativa, sendo marcada linguisticamente pela vogal pré-radical - $i$-. Argumenta-se, no entanto, que a apropriação da vogal pré-radical - $i$ - para marcar a construção depacientiva constitui, não somente uma forma de os falantes utilizarem os próprios recursos oferecidos pela língua para atribuir novas significações, mas também uma aproximação aos sentidos associados ou marcados pela vogal pré-radical - $i$-, dentre eles aqueles associados à voz média, as duas, possivelmente, sendo extensões da versão subjetiva em georgiano.

Pela exposição que fizemos dos sentidos atribuídos tanto à construção depacientiva quanto aos da voz média, é possível traçar algumas similaridades semânticas entre as duas construções, argumentando-se que, assim como a construção média, a construção depacientiva também envolve certo foco no domínio do sujeito.

Como foi visto, na construção média, a ação permanece dentro da própria esfera do sujeito, i.e., é dirigida a ele e não a outro participante, afetando o sujeito ou seus interesses. Na construção depacientiva, ainda que a ação não se volte ou afete o sujeito, é, às vezes, uma ação característica daquele indivíduo, como a denotar uma propriedade do agente. Esse significado, ainda que não constitua uma ação que afete ou se volte ao sujeito, parece, em menor grau, estar dentro do domínio do sujeito, tornando, por esse motivo, a codificação do tema irrelevante ou genérica, i.e., sendo evocado apenas de forma esquemática. É daí, portanto, que surge a semelhança, tanto no que se refere à conceitualização de eventos que evocam, quanto no que diz respeito à formação, nesse caso, a vogal pré-radical $-i$-.

Em termos de formação de um continuum de construções, de um lado, haveria a construção transitiva ativa com dois participantes, perfilando toda a cadeia de ação, i.e., a interação entre agente e paciente, do outro, haveria a construção média que envolve apenas um participante, focando no domínio do sujeito, a ação referindo-se ou o afetando de certa forma. No meio dessas duas construções, surge a construção depacientiva que, embora evoque conceitualmente toda a cadeia de ação, apenas um participante é focado, o agente, o processo temático sendo evocado apenas esquematicamente, i.e., a construção 
depacientiva perfilaria somente o agente como fluxo de energia e a ação por ele desencadeada.

Por esse lado, a construção depacientiva se aproximaria da construção ativa ao evocar, ainda que esquematicamente, toda a cadeia de ação, por outro, se aproximaria de uma construção média, com um participante e focando no domínio do sujeito, característica esta que acreditamos, ainda que de forma mais branda, também está presente na significação da construção depacientiva.

Argumenta-se ainda que as duas construções em georgiano, média (ou os sentidos associados a ela) e depacientiva, constituem possivelmente extensões dos sentidos associados à vogal pré-radical $-i$-, principalmente, em relação ao seu sentido como versão subjetiva em georgiano.

Como foi discutido na seção 5.4, lexemas verbais são aprendidos no contexto das construções que aparecem e vice versa, i.e., é por meio de arraigamento e convencionalização do uso de um lexema verbal em determinada construção que é possível dizer que o verbo possui o sentido associado àquela construção, ou seja, o significado associado à construção passa a fazer parte do network de construções, ou sentidos, associadas ao lexema verbal.

Assim como um lexema verbal, um item dito como gramatical, como as vogais pré-radicais, também é aprendido no contexto das construções em que convencionalmente aparece, o significado daquela construção passando a fazer parte do network de sentidos associados àquele morfema ou item gramatical. É importante salientar que, na CG, léxico e gramática formam um continuum, diferindo apenas em termos de complexidade simbólica.

Dessa forma, a descrição de uma unidade linguística, como a vogal pré-radical - $i$ , depende da descrição do conjunto de frames estruturais em que convencionalmente aparece, uma dimensão de sua complexidade sendo, portanto, sua ocorrência em contextos estruturais maiores. Nas palavras de Langacker (2008) "to some extent, a lexeme's meaning is shaped by the frames it occurs in".

Ademais, como Gurevich (2006) ressalta, o sentido de uma vogal pré-radical somente pode ser definido dentro de contextos morfossintáticos maiores, nos termos da $\mathrm{CG}$, no contexto das construções em que aparece.

Por essa perspectiva, através de arraigamento e convencionalização, os significados associados a construções em que a vogal pré-radical - $i$ - aparece, como, dentre 
outras, a construção passiva, seu uso como versão subjetiva, e, como acreditamos, a construção depacientiva e construções com sentidos associados à voz média, fazem parte do network de sentidos associados à vogal pré-radical - $i$-, cada qual a formar, portanto, esquemas abstraídos de similaridades apreendidas entre diferentes instâncias.

Supõe-se, em particular, que as construções com sentidos associados à voz média e construções depacientivas marcadas pela vogal pré-radical - $i$ - são, possivelmente, extensões do já bastante arraigado e produtivo esquema construcional de seu uso como versão subjetiva, partindo-se de similaridades semânticas entre as construções e a formar construções com diferentes significados.

\subsubsection{Verbos depoentes chamados de Tipo 1}

Os verbos chamados por Tuite (2002) de depoentes de Tipo 1 e exemplificados em (36b) e (37) são verbos caracterizados pela omissão de um argumento relativamente a verbos bitransitivos ativos dos quais seriam derivados. Normalmente, são verbos que denotam eventos de transferência como 'dar' (36) e 'transmitir' (37).

Em comparação a uma construção bitransitiva prototípica que possui três participantes perfilados, agente, tema e recipiente (cf. 36a), as construções mencionadas no parágrafo anterior omitem um participante, usualmente o objeto indireto, i.e., o participante que recebe o objeto direto (dinheiro, informação, etc.).

O diagrama abaixo, retirado de Langacker (2008), ilustra um evento prototípico de transferência em que três participantes são perfilados. O agente, como o trajetor que inicia o ato de transferência, e o tema e recipiente, ambos como marcos, já que são igualmente participantes perfilados, inclusive, não havendo em georgiano diferença em marcação nas Séries I do Presente, os dois no caso dativo. ${ }^{13}$

\footnotetext{
${ }^{13}$ Segundo Langacker (2008), por serem ambos, tema e recipiente, participantes com direito à proeminência focal, cada língua poderia fazer uso de diferentes estratégias para dar maior saliência para um ou para outro, ou mesmo, em alguns casos, para os dois, o recipiente constituindo o segundo marco.
} 


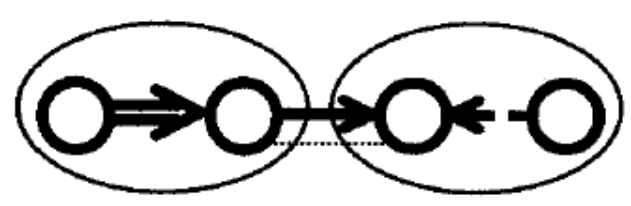

Figura 5: Construção bitransitiva (LANGACKER, 2008, p.242)

O diagrama mostra uma cadeia de ação em que o agente, a partir do seu domínio, faz com que o objeto se mova, ainda que metaforicamente, em direção ao domínio do recipiente que, então, recebe o objeto.

De forma similar aos verbos depacientivos, esses verbos depoentes parecem codificar uma conceitualização alternativa desses eventos relativamente a uma construção bitransitiva canônica. Por essa perspectiva, a vogal pré-radical $-i-$, em conjunto com morfologia verbal característica, passa a marcar nesses verbos um evento mais marcado semanticamente, um construal distinto, i.e., uma maneira diferente de os falantes construírem uma determinada situação.

É interessante notar que contrária à sua função de versão verbal (usualmente servindo para codificar a presença de um argumento extra), a vogal pré-radical $-i$ - - tanto nesses verbos quanto na construção depacientiva que vimos anteriormente e também a construção passiva -, parece marcar a ausência de um argumento, e não adição.

Nas construções sob foco, o recipiente, aquele que receberia a informação ou objeto, seria irrelevante ou em certos casos estaria na perspectiva do próprio falante. Em (36b), o argumento que corresponderia a quem o dinheiro estaria sendo entregue é omitido, sendo apenas relevante a codificação do agente e do objeto a ser entregue. Em (37), temos situação semelhante, o recipiente é omitido, i.e., para quem as notícias são transmitidas não é informação relevante. Na sentença, ainda há o significado de que aquele evento é habitual ou ocorre de forma regular.

Como citado anteriormente, a própria ausência de um argumento já acarretaria uma maior saliência do participante restante, visto que se anula a competição entre participantes. Dessa forma, ao se omitir o recipiente, a proeminência recairia plenamente nos participantes restantes, o agente, o trajetor, e o tema, como único marco, passando a receber exclusivamente a proeminência secundária.

A Figura 6, abaixo, ilustra o diagrama desse tipo de construções com verbos de transferência com somente dois participantes perfilados: 


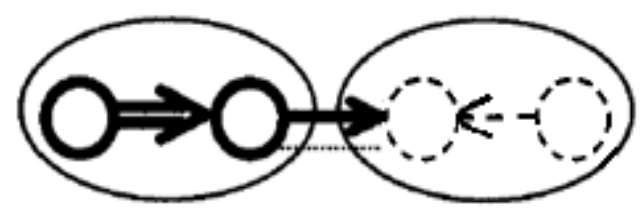

Figura 6: Verbos de transferência com dois participantes

$\mathrm{Na}$ figura, apenas o trajetor e o tema, que é movido de um domínio a outro, são perfilados na cadeia de ação. $O$ recipiente e o consequente recebimento do tema em seu domínio não são codificados, sendo evocados apenas esquematicamente.

As três construções em (36), desse modo, representam três distintas formas de se conceitualizar o mesmo evento, sendo dada, em cada construção, maior proeminência a elementos diferentes. Em (36a), temos a codificação de um evento bitransitivo canônico em que toda a cadeia de ação é perfilada; em (36c), há uma construção passiva que codifica a mesma situação, mas em que apenas o tema e o recipiente são perfilados, o agente não sendo informação relevante ou necessária; em (36b), por fim, temos uma construção que serve como alternativa às duas anteriores, codificando o mesmo evento, porém de forma a dar proeminência a somente o agente e tema. 


\section{CONSIDERAÇÕES FINAIS}

Na literatura tradicional sobre a língua, a análise do sistema verbal parte de uma visão de classes, em que os verbos são classificados, sobretudo, considerando-se características morfológicas em comum. Ainda que tenham sua utilidade como forma de se observar certas generalizações na língua, divisões restritas como essas falham em capturar a riqueza conceitual característica do sistema verbal.

Um exemplo são os grupos de verbos marginais sob foco, por apresentarem peculiaridades morfológicas, sintáticas ou semânticas em relação aos outros membros das classes nas quais são inseridos, são considerados como idiossincráticos ou como exceção, pouca atenção lhes sendo dada.

Se, no entanto, deixarmos de partir de uma visão restrita de classes e passarmos a uma análise que considera construções, pareamentos de forma e significado, como ponto de partida, é possível se chegar a um entendimento mais intuitivo e aprofundado dessas construções marginais.

Com o intuito, portanto, de oferecer uma análise alternativa dessas construções, foi feita uma transição entre a visão tradicional e nossa análise ao fim. Os capítulos 2 e 3 foram dedicados, portanto, à apresentação e descrição da abordagem tradicional do sistema verbal e de outros aspectos relevantes ao entendimento desses verbos. Os grupos de verbos marginais sob foco foram introduzidos e inicialmente descritos no capítulo 4 .

O primeiro capítulo foi dedicado à introdução de conceitos fundamentais, pressupostos e metodologia utilizada para delimitar e analisar nosso objeto de estudo.

No capítulo 5, a base teórica desta pesquisa, que constitui a Linguística Cognitiva, em particular, a Gramática Cognitiva de Langacker, foi apresentada em conjunto com a análise proposta das construções marginais estudadas.

Como foi argumentado nesta dissertação, essas diferentes construções marginais discutidas, constituem, cada qual, um processo de significação coerente, representando construals distintos, i.e., maneiras diferentes de se construir eventos, e codificados na língua de forma particular.

Por essa perspectiva, a 'idiossincrasia', a priori, distinguida nessas construções nada mais é que o reflexo de conceitualizações distintas. O que evidencia formas de se perceber ou construir eventos por parte dos falantes, i.e., a construção de significado não 
é algo objetivamente discernível no mundo ou nos eventos em si, é uma escolha do falante como sujeito conceitualizador que, através do impulso em dar novas significações, faz uso das estratégias de codificação linguísticas disponibilizadas pela própria língua. 


\section{REFERÊNCIAS BIBLIOGRÁFICAS}

AARTS, Bas. Syntactic Gradience: The Nature of Grammatical Indeterminacy. New York: Oxford University Press, 2007.

ACHARD, Michel. Representation of Cognitive Structures: Syntax and Semantics of French Sentential Complements. Cognitive Linguistics Research 11. Berlin: Mouton de Gruyter, 1998.

ACHARD, M., DIRVEN, R., IBANEZ, F. J. R. de M., KRISTIANSEN, G. (eds.). Cognitive Linguistics Current Applications and Future Perspectives. Berlin/New York: Mouton de Gruyter, 2006.

AMIRIDZE, N. Reflexivization strategies in Georgian. Ph. D. dissertation. Universiteit Utrecht, 2006.

ANDERSON, S. R. On representations in morphology. Case agreement and inversion in Georgian. Natural Language and Linguistic Theory, 2(2):157-218, 1984.

ANDERSON, Gregory \& GUREVICH, Olga. Toward a Typology of Version: Formal and Functional Perspectives. 2005.

ARONSON, H. I. Towards a semantic analysis of case and subject in Georgian. Lingua, 25:291-301, 1970.

Georgian: a reading grammar. Columbus: Slavica, 1982a.

On the status of version as a grammatical category in Georgian. Folia Slavica 5: 66-80, 1982b.

ARONSON, H I; KIZIRIA, D. Georgian language and culture: a continuing course. Slavica, 1999.

ASATIANI, Rusudan. nebelobis semant'ik'uri k'at'egoriis gamoxat'va kartul zmnebsi [The expression of volition in Georgian verbs]. In Z. Sarjveladze, editor, Works of the Chair of the Georgian Language of the Tbilisi State Pedagogical University, volume 4, pages 25-36. Tbilisi State Pedagogical University Press, Tbilisi, 1998. (in Georgian). 
BHASKARARAO, Peri \& SUBBARAO, K. V. Non-nominative Subjects, vol. I. Amsterdam/Philadelphia: John Benjamins Publishing Company, 2004a.

Non-nominative Subjects, vol. II. Amsterdam/Philadelphia: John Benjamins Publishing Company, 2004b.

CAMPBELL, L. \& HARRIS, A. C. Historical Syntax in Cross-Linguistic Perspective. Cambridge: Cambridge University Press, 1995.

CATE, B.D. \& ZEEVAT, H.W. Logic, Language, and Computation: 6th International Tbilisi Symposium on Logic, Language, and Computation, TbiLLC 2005 Batumi, Georgia, September 12-16, 2005. Revised Selected Papers. Berlin, Heidelberg: Springer Berlin Heidelberg, 2007.

CHERCHI, Marcello. Modern Georgian morphosyntax. A grammatico-categorial hierarchy-based analysis with special reference to indirect verbs and passives of state. Wiesbaden: Harrassowitz Verlag, 1997.

CROFT, William. Syntactic Categories and Grammatical Relations: The Cognitive Organization of Information. Chicago: University of Chicago Press, 1991.

. Radical Construction Grammar: Syntactic Theory in Typological Perspective.

Oxford: Oxford University Press, 2001.

CROFT, William \& CRUSE, Alan. Cognitive Linguistics. Cambridge Textbooks in Linguistics. Cambridge: Cambridge University Press, 2004.

CUYCKENS, H. \& GEERAERTS, D. (eds.). The Oxford Handbook of Cognitive Linguistics. New York: Oxford University Press, 2007.

DIXON, R. M. W. Ergativity. Cambridge: Cambridge University Press. 1994.

DIXON, R. M. W. \& AIKHENVALD, A. Changing Valency: Case studies in transitivity. Cambridge University Press, 2000.

ELLIS, Nick C. \& ROBINSON, Peter. The Handbook of Cognitive Linguistics and Second Language Acquisition. New York/London: Routledge, 2008. 
EVANS, Vyvyan. A Glossary of Cognitive Linguistics. Edinburgh: Edinburgh University Press, and Salt Lake City: University of Utah Press, 2007.

EVANS, Vyvyan and GREEN, Melanie. Cognitive Linguistics: An Introduction. Mawhaw, N.J.: Erlbaum, 2006.

EVANS, Vyvyan, BERGEN, Benjamin K. and ZINKEN, Jörg (eds.). The Cognitive Linguistics Reader. London: Equinox, 2006.

FOX, Barbara \& HOPPER, Paul. Voice: Form and Function. Amsterdam/Philadelphia: John Benjamins Publishing Company, 1994.

GEERAERTS, Dirk (ed.). Cognitive Linguistics: Basic Readings. Cognitive Linguistics Research 34. Berlin: Mouton de Gruyter, 2006.

GERRITSEN, N. Russian Reflexive Verbs-In search of unity and diversity. Studies in Slavic and general linguistics. Vol.15. Amsterdam: Rodopi. 1990.

GIVÓN, Talmy. Syntax: An Introduction, vol. 1, 2nd ed. Amsterdam/Philadelphia: John Benjamins Publishing Company, 2001a.

Syntax: An Introduction, vol. 2, 2nd ed. Amsterdam/Philadelphia: John Benjamins Publishing Company, 2001b.

GOLDBERG, Adele. Constructions: A Construction Grammar Approach to Argument Structure. Chicago: Chicago University Press, 1995.

GOLDBERG, Adele (ed.). Conceptual Structure, Discourse, and Language. Stanford, CA: CSLI Publications, 1996.

GOLDBERG, Adele. 'Construction grammar', in E. K. Brown and J. E. Miller (eds), Concise Encyclopedia of Syntactic Theories. New York: Elsevier Science, 1997.

GUREVICH, Olga I. Constructional Morphology: The Georgian Version. Ph. D. dissertation. University Of California. Berkeley, 2006.

HARRIS, Alice C. Georgian syntax: a study in relational grammar. New York: Cambridge University Press, 1981. 
Diachronic syntax: the Kartvelian case (Syntax and syntax 18). New York: Academic Press, 1985.

. History in Support of Synchrony. Proceedings of the 30th Annual Meeting of the Berkeley Linguistic Society, 2004.

HASPELMATH, M. Explaining the Ditransitive Person-Role Constraint: a usage-based account. Constructions 2/2004, 49 pp. University of Düsseldorf, 2004.

HEWITT, George. Review article. Revue des études géorgiennes et caucasiennes 3: 173213. 1987

Georgian: A Structural Reference Grammar. Amsterdam/Philadelphia: John Benjamins Publishing Company, 1995.

Georgian: A learner's Grammar. London: Routledge, 1996.

HILLERY, Patrick J., The Georgian Language: An outline grammatical summary, available at www.armazi.com. Consultado em 2009.

HOLISKY, Dee Ann: Aspect and Georgian medial verbs. Delmar, NY: Caravan Press, 1981. 274. 1987.

. The case of the intransitive subject in Tsova-Tush (Batsbi). Lingua 71: 245-

HOPPER, Paul \& THOMPSON, Sandra. Transitivity in grammar and discourse. Language 56: 251-99, 1980.

JANSSEN, Theo \& REDEKER, Gisela (eds.). Cognitive Linguistics: Foundations, Scope, and Methodology. Cognitive Linguistics Research 15. Berlin: Mouton de Gruyter, 1999.

KEMMER, Suzanne. The Middle Voice. Typological Studies in Language 23. Amsterdam: John Benjamins, 1993. 
KLAIMAN, M. H. Grammatical Voice (Cambridge Studies in Linguistics 59). Cambridge: Cambridge University Press, 1991.

KUNO, Susumu \& KABURAKI, Etsuko. Empathy and Syntax. Linguistic Inquiry Volume 8 Number 4, MIT Pres,1977, p. 627-672.

LANGACKER, Ronald W. Foundations of Cognitive Grammar, vol. 1: Theoretical Prerequisites. Stanford: Stanford University Press, 1987.

Foundations of Cognitive Grammar, vol. 2: Descriptive Application. Stanford: Stanford University Press, 1991.

Grammar and Conceptualization. Cognitive Linguistics Research 14. Berlin: Mouton de Gruyter, 1999.

Concept, Image, and Symbol: The Cognitive Basis of Grammar. 2nd ed. Cognitive Linguistics Research 1. Berlin: Mouton de Gruyter, [1991] 2002.

Press, 2008.

Cognitive Grammar: A Basic Introduction. New York: Oxford University Investigations in Cognitive Grammar. Cognitive Linguistics Research 42. Berlin: Mouton de Gruyter, 2009a.

Cognitive (construction) grammar. Cognitive Linguistics, 20(1), 167-176. doi:10.1515/COGL.2009.010, 2009b.

LEE, David. Cognitive Linguistics: An Introduction. Melbourne: Oxford University Press, 2001.

LICHTENBERK, F. Reciprocals and related meanings in To'aba'ita. In: NEDJALKOV, V. P. (Ed.). Reciprocal constructions. 5 volumes. Amsterdam/Philadelphia: John Benjamins Publishing Company, 2007, p. 1547-1571.

MACLAURY, R. E. \& TAYLOR, J. R. (eds.). Language and the Cognitive Construal of the World. Trends in Linguistics: Studies and Monographs 82. Berlin/New York: Mouton de Gruyter, 1995. 
MALDONADO, R. A media voz: problemas conceptuales del clítico SE em español. Mexico: Instituto de Investigaciones Filologicas, UNAM, 2002.

. Middle as a basic voice system. In Lilian Guerrero, Sergio Ibáñez \& Valeria Belloro (eds.), Studies in role and reference grammar. México: Instituto de Investigaciones Filológicas, UNAM, 2009.

MEDOVÁ, L. Reflexive Clitics in the Slavic and Romance Languages. Ph. D. dissertation. Princeton Universtiy, 2009.

MELIKISHVILI, Irine. Georgian as an Active/Ergative Split Language. Bulletin of the Georgian National Academy of Sciences, vol. 2, no. 2, Tbilisi, 2008.

NAESS, Åshild. Prototypical Transitivity. Amsterdam/Philadelphia: John Benjamins Publishing Company, 2007.

NEDJALKOV, V. P. (ed.). Reciprocal constructions. 5 volumes. Amsterdam: John Benjamins Publishing Company, 2007.

RAUH, Gisa. Syntactic Categories. Their Identification and Description in Linguistic Theories. New York: Oxford University Press, 2010.

RAYFIELD, Donald, et al. (eds). A Comprehensive Georgian-English Dictionary, 2 vols, London: Garnett Press, 2006.

RICE, Sally. Towards a Cognitive Model of Transitivity. Ph.D. dissertation, University of California, San Diego, 1987.

RUDZKA-OSTYN, Brygida (ed.). Topics in Cognitive Linguistics. Amsterdam: John Benjamins, 1988.

SHANIDZE, A. kartuli gramat'ik'is sapudzvlebi, 1: morpologia. (Fundamentals of Georgian grammar, 1: Morphology). Tbilisi: Tbilisis universit'et'is gamomcemloba, 1973.

SHIBATANI, M. (ed.). Passive and Voice (Typological Studies in Language 16) Amsterdam/Philadelphia: John Benjamins Publishing Company, 1988. 
SHIBATANI, M. \& THOMPSON, S. A. (eds.) Grammatical Constructions: Their Form and Meaning. Oxford: Oxford University Press, 1996.

SHOPEN, Timothy (ed.). Language typology and syntactic description, vol. 3: Grammatical categories and the lexicon. Cambridge: Cambridge University Press, 2007.

TALMY, Leonard. Toward a Cognitive Semantics, vol. 1: Concept Structuring Systems. Cambridge, Mass.: MIT Press, and London: Bradford, 2000a.

Toward a Cognitive Semantics, vol. 2: Typology and Process in Concept Structuring. Cambridge, Mass.: MIT Press, 2000b.

TAYLOR, John. Cognitive Grammar. Oxford Textbooks in Linguistics. Oxford: Oxford University Press, 2002.

Linguistic Categorization: Prototypes in Linguistic Theory. 3rd ed. Oxford: Oxford University Press/Clarendon, 2004.

TSCHENKÉLI, K. Einführung in die georgische Sprache. Zürich: Amirani Verlag, 1958a.

. Einführung in die georgische Sprache. Band II. Zürich: Amirani Verlag, 1958b.

Georgisch-deutsches Wörterbuch. Zürich: Amirani Verlag, 1960-1974.

TUITE, KEVIN. Indirect transitives in Georgian. Proceedings of the 13th annual meeting of the Berkeley Linguistics Society (BLS 13), 296-309, 1987.

Paradigm recruitment in Georgian. NSL 8: Linguistic Studies in the NonSlavic Languages of the Commonwealth of Independent States and the Baltic Republics, H. Aronson (editor). Chicago Linguistics Society; 375-387, 1996

Kartvelian Morphosyntax. Number agreement and morphosyntactic orientation in the South Caucasian languages. (Studies in Caucasian Linguistics, 12). München: Lincom Europa, 1998. 
Deponent verbs in Georgian. Philologie, Typologie und Sprachstruktur: Festschrift für Winfried Boeder zum 65. Geburtstag, Wolfram Bublitz, Manfred von Roncador, Heinz Vater (ed.), 375-389. Frankfurt am Main: Peter Lang Verlag, 2002.

Liminal morphosyntax: Georgian deponents and their kin. Chicago Linguistics Society, vol 39: 774-788, 2007.

Agentless transitive verbs in Georgian. Anthropological Linguistics, 51 \#3-4: 269-295, 2009.

VERHAGEN, Arie. Construal and Perspectivization. In: CUYCKENS, H. \& GEERAERTS, D. (eds.). The Oxford Handbook of Cognitive Linguistics. New York: Oxford University Press, 2007.

WIER, Thomas R. Georgian Morphosyntax and Feature Hierarchies in Natural Language. Ph. D. dissertation. University Of Chicago, 2011.

WOODS, Christopher. The Grammar of Perspective: The Sumerian Conjugation Prefixes As a System of Voice. Cuneiform Monographs, vol. 32. Leiden: Brill, 2008. 


\section{APÊNDICE: COMPILAÇÃO, PARA REFERÊNCIA, DOS EXEMPLOS DO GEORGIANO UTILIZADOS AO LONGO DESTE TEXTO}

\section{Seção 2.3.1 - p. 30}

(1a) kal-eb-i saxl-s a-shen-eb-en.

mulher-PL-NOM casa-DAT VPR-construir-ST-3ANOM.PL

As mulheres estão construindo uma casa.

(1b) kal-eb-ma saxl-i a-a-shen-es.

mulher-PL-ERG casa-NOM PV-VPR-construir-3AERG.PL.AOR.INDIC

As mulheres construíram a casa.

(1c) kal-eb-s turme saxl-i a-u-sheneb-i-a-t.

mulher-PL-DAT aparentemente casa.NOM PV-VPR-construir-SM-3ANOM-PL.DAT As mulheres aparentemente construíram a casa.

Seção 2.3.2 - p. 31

(2a) k'alam-i qoveltvis t'qd-eb-a

caneta-NOM sempre quebrar-ST-3ANOM.SG

A caneta está sempre quebrando.

(2b) k'alam-i ga-t'qd-a gushin caneta-NOM PV-quebrar-3ANOM.SG.AOR.INDIC ontem A caneta quebrou ontem.

(2c) k'alam-i turme ga-t'exil-a caneta-NOM aparentemente PV-quebrar-3ANOM.SG A caneta aparentemente quebrou.

\section{Seção 2.3.2 - p. 32}
(3) mt'ver-i
a-par-i-a
iat'ak'-ze
poeira-NOM VPR-estar.espalhado-SM-3ANOM.SG
chão-POSP

A poeira está espalhada no chão.

(HARRIS, 1981)

\section{Seção 2.3.3 - p. 33}
(4a) k'ac-i musha-ob-s qoveldghe
homem-NOM trabalhar-ST-3ANOM.SG todo.dia O homem trabalha todo dia.


(4b) k'ac-eb-ma i-mushav-es

homem-PL-ERG VPR-trabalhar-3AERG.PL.AOR.INDIC

Os homens trabalharam.

(4c) k'ac-eb-s turme u-mushav-i-a-t homem-PL-DAT aparentemente VPR-trabalhar-SM-3ANOM-PL.DAT Os homens aparentemente trabalharam.

\section{Seção 2.3.4 - p. 34}

(5a) bich'-eb-s u-qvar-t gogona garoto-PL-DAT VPR-amar-PL menina.NOM Os garotos amam a menina.

(5b) bich'-eb-s e-qvar-eb-a-t gogona garoto-PL-DAT VPR-amar-ST-3ANOM-PL menina.NOM Os garotos amarão a menina

(5c) bich'-eb-s qvar-eb-i-a-t gogona garoto-PL-DAT amar-ST-SM-3ANOM-PL menina.NOM Os garotos aparentemente amaram a menina.

Seção 3.1.2 - p. 37

(6) surat-i k'edel-ze h-k'id-i-a quadro-NOM parede-POSP 3BDAT.SG-suspender-SM-3ANOM.SG O quadro está pendurado na parede.

(HEWITT, 1995)

\section{Seção 3.1.2 - p. 37}

(7) mezobel-s cecxl-i u-nt-i-a saxl-shi vizinho-DAT fogo-NOM VPR-estar.aceso-SM-3ANOM.SG casa-POSP $\mathrm{O}$ vizinho tem fogo aceso em casa (lit. o fogo está aceso na casa do vizinho).

(HILLERY, 2009)

\section{Seção 3.1.3 - p. 38}

(8) mdzghol-s benzin-i gaza-ze da-u-mtavr-d-a motorista-DAT gasolina-NOM caminho-POSP PV-VPR-acabar-PI-3ANOM.SG.AOR.INDIC $\mathrm{O}$ motorista ficou sem gasolina no caminho. 


\section{Seção 3.2 - p. 39}

(9) gakvetil-eb-i male mo-mzad-d-eb-a lição-PL-NOM logo PV-estar.pronta-PI-ST-3ANOM.SG Logo as lições estarão prontas.

(ARONSON, 1982a)

\section{Seção 3.2 - p. 40}

(10a) mat da-e-drik'-a-t mat-i p'ir-eb-i mic'-isa-k'en. 3PL-DAT PV-VPR-voltar-3ANOM-PL seu-NOM rosto-PL-NOM chão-GEN-em.direção "Eles voltaram suas faces em direção ao chão."

(10b) tu g-i-q'var-d-e(s)-t tkven tkven-i moq'vare-eb-i se 2BDAT-VPR-amar-PI-3ANOM-PL 2PL.DAT seu.PL-NOM amante-PL-NOM "Se vocês amarem aqueles que os amam..."

(TUITE, 1998)

\section{Seção 3.2 - p. 40}

(11a) mat da-x-e-drik'-nes p'ir-n-i mat-n-i kweq'n-ad 3PL.DAT PV-3BDAT-VPR-voltar-3ANOM.PL rosto-PL-NOM seu-PL-NOM terra-AD "Eles voltaram suas faces em direção ao chão." [Luke 24:5 (Xanm.; c. 500 AD)]

(11b) uk'wetu g-i-q'war-d-en tkwen moq'ware-n-i tkwen-n-i se 2BDAT-VPR-amar-PI-3ANOM.PL 2PL.DAT amante-PL-NOM seu-PL-NOM "Se vocês amarem aqueles que os amam..." [Luke 6:32 (Xanm.)]

(TUITE, 1998)

\section{Seção 3.2 - p. 41}

(12a) nino-s bavshv-i da-e-k'arg-a Nino-DAT criança-NOM PV-VPR-perder-3ANOM.SG.AOR.INDIC Nino perdeu a criança.

(12b) nino-s bavshv-eb-i da-e-k'arg-a Nino-DAT criança-PL-NOM PV-VPR-perder-3ANOM.AOR.INDIC Nino perdeu as crianças.

(12c) gogon-eb-s bavshv-i da-e-k'arg-a-t menina-PL-DAT criança-NOM PV-VPR-perder-3ANOM.AOR.INDIC-PL As meninas perderam a criança. 
(12d) gogon-eb-s bavshv-eb-i da-e-k'arg-a-t

menina-PL-DAT criança-PL-NOM PV-VPR-perder-3ANOM.AOR.INDIC-PL

As meninas perderam as crianças.

(ASATIANI, 1998)

Seção 3.2 - p. 42

(13a) es teoria / es teori-eb-i mas aint'eres-eb-s esse teoria.NOM esse teoria-PL-NOM 3SG.DAT interessar-ST-3ANOM.SG

Essa teoria/Essas teorias interessam-no.

(13b) es teoria / es teori-eb-i mat aint'eres-eb-t esse teoria.NOM esse teoria-PL-NOM 3PL.DAT interessar-ST-PL Essa teoria/Essas teorias interessam-nos.

(13c) mat ra ac'ux-eb-t

3PL.DAT que incomodar-ST-PL

O que os incomoda?

(ARONSON, 1999)

\section{Seção 3.2 - p. 42}
(14a) k'arg-i moxseneba msmenel-eb-s aint'eres-eb-s bom-NOM fala.NOM ouvinte-PL-DAT interessar-ST-3ANOM.SG Uma boa fala interessa os ouvintes.

(ARONSON, 1999)

\section{Seção 4.1.1 - p. 49}

(15) Verbos direto-indiretos de Classe II com VPR - $e$-.
a. kurd-i ga-e-p'ar-a p'oliciel-eb-s ladrão-NOM PV-VPR-escapar-3ANOM.AOR.INDIC polícia-PL-DAT

a'. p'oliciel-eb-s ga-e-p'ar-a-t kurd-i polícia-PL-DAT PV-VPR-escapar-3ANOM.AOR.INDIC-PL.DAT ladrão-NOM

O ladrão escapou da polícia.
b. mepe e-chven-eb-a xalx-s rei.NOM VPR-aparecer-ST-3ANOM.SG pessoas-DAT $\mathrm{O}$ rei se mostra para as pessoas. 
b'. deda-s e-chven-eb-a shvil-i sizmar-shi mãe-DAT VPR- aparecer-ST-3ANOM.SG criança-NOM sonho-POSP A criança aparece para a mãe no sonho. [A mãe vê a criança aparecendo.]

c. gak'vetil-i e-c'q'-eb-a moc'ape-eb-s xval rva lição-NOM VPR-começar-ST-3ANOM.SG estudante-PL-DAT amanhã oito saat-ze hora-POSP

c'. moc'ape-eb-s e-c'q'-eb-a-t gak'vetil-i xval rva estudante-PL-DAT VPR-começar-ST-3ANOM-PL.DAT lição-NOM amanhã oito saat-ze hora-POSP

A lição começa para os estudantes amanhã às oito horas.

[Adaptados de Tschenkeli (1958a)]

Seção 4.1.1 - p. 49

(16) Verbos direto-indiretos de Classe II com VPR -e-.

a. ded-eb-s e-chven-eb-i-an tavianti bavshv-eb-i mãe-PL-DAT VPR-aparecer-ST-SM-3ANOM.PL suas criança-PL-NOM As crianças apareceram diante de suas mães.

a'. ded-eb-s e-chven-eb-a-t tavianti bavshv-eb-i mãe-PL-DAT VPR-aparecer-ST-3ANOM-PL.DAT suas criança-PL-NOM As crianças apareceram para suas mães (em sonho).

b. damsheul dzaghl-eb-s mgl-eb-i e-c-nen famintos cão-PL-DAT lobo-PL-NOM VPR-cair-3ANOM.PL Os lobos caíram sobre os cães famintos.

b'. damsheul dzaghl-eb-s sun-i e-c-a-t famintos cão-PL-DAT odor-NOM VPR-cair-3ANOM-PL Os cães famintos sentiram o odor.

[Adaptados de Tuite (1998)]

Seção 4.1.1 - p. 50 
(17) Verbos direto-indiretos de Classe II com VPR -e-.

a. bavshv-eb-i e-mal-eb-i-an ertmanet-s criança-PL-NOM VPR-esconder-ST-SM-3ANOM.PL um.ao.outro-DAT

a'. bavshv-eb-s e-mal-eb-a-t ertmanet-i criança-PL-DAT VPR-esconder-ST-3ANOM-PL.DAT um.ao.outro-NOM

As crianças se escondem umas das outras.

b. bavshv-eb-i da-e-k'arg-nen criança-PL-NOM PV-VPR-perder-3ANOM.PL

ertmanet-s um.ao.outro-DAT

ertmanet-i

b'. bavshv-eb-s da-e-k'arg-a-t criança-PL-DAT PV-VPR-perder-3ANOM-PL.DAT

As crianças perderam-se umas das outras.

[Adaptados de Tuite (1998)]

\section{Seção 4.1.1 - p. 50}

(18) Verbos direto-indiretos de Classe II com VPR -e-.
a. bavshv-eb-i e-mal-eb-i-an ded-eb-s criança-PL-NOM VPR-esconder-ST-SM-3ANOM.PL mãe-DAT As crianças estão se escondendo de suas mães.
a'. bavshv-eb-s e-mal-eb-a-t ded-eb-i criança-PL-DAT VPR-esconder-ST-3ANOM-PL.DAT mães-NOM As crianças estão se escondendo de suas mães (no entanto, não o fazem de propósito).

\section{Seção 4.1.1 - p. 51}

(19) Contraste entre verbo direto de Classe I e verbo de Classe II direto-indireto.

a. am sak'itxis axsnisas bevri dro da-m-e-k'arg-a esse questão.GEN explicação muito tempo PV-1BDAT.SG-VPR-perder-3ANOM.AOR.INDIC Eu perdi muito tempo durante a explicação dessa questão (eu não tinha a intenção). 
a'. bevri dro da-v-k'arg-e

muito tempo PV-1AERG.SG-perder-AOR.INDIC

Eu perdi muito tempo.

[Adaptados de Asatiani (1998)]

Seção 4.1.1 - p. 51

(20) Verbos de Classe II direto-indiretos sem vogal pré-radical -e-.

a. kal-eb-i she-xvd-eb-i-an kmr-eb-s

mulher-PL-NOM PV-encontrar-ST-SM-3ANOM.PL marido-PL-DAT

As mulheres encontrarão os maridos.

a'. kal-eb-i she-xvd-eb-a-t kmr-eb-s

mulher-PL-NOM PV-encontrar-ST-3ANOM.AOR.INDIC-PL.DAT marido-PL-DAT

Os maridos encontrarão as mulheres (por acaso).

[Adaptados de Tuite (1998)]

Seção 4.1.1 - p. 51

(21) Verbos direto-indiretos de Classe II com a vogal pré-radical - $u$-.

a. es saxl-i da-u-jd-a chem-s mshobl-eb-s esta casa-NOM PV-VPR-custar-3ANOM.SG.AOR.INDIC meu-DAT pais-PL-DAT bevri pul-i

muito dinheiro-NOM

a'. chem-s mshobl-eb-s da-u-jd-a-t es saxli meu-DAT pais-PL-DAT PV-VPR-custar-3ANOM.AOR.INDIC-PL esta casa-NOM bevri pul-i

muito dinheiro-NOM

Esta casa custou muito dinheiro aos meus pais.

[Adaptados de Tschenkeli (1958a)]

Seção 4.1.1 - p. 52

(22) Verbos direto-indiretos de Classe I 
a. umcros-eb-s upros-eb-i a-c'ux-eb-d-nen

mais.jovens-PL-DAT mais.velhos-PL-NOM VPR-incomodar-ST-SA-3ANOM.PL

Os mais velhos estavam incomodando os mais jovens.

a'. umcros-eb-s ... ar a-c'ux-eb-d-a-t es

mais.jovens-PL-DAT não VPR-incomodar-ST-SA-3ANOM-PL.DAT essa

morchileba

submissão.NOM

Os mais jovens não se incomodaram em se submeter (à regra) [lit. aos mais jovens não incomodou se submeter à regra].

b. masc'avlebel-i mosc'avle-s a-xasiat-eb-s

professor-NOM estudante-DAT VPR-caracterizar-ST-3A NOM.SG

O professor caracteriza o estudante.

b'. am mosc'avle-s k'argi michveva a-xasiat-eb-s

esse estudante-DAT bom hábito.NOM VPR-caracterizar-ST-3ANOM.SG

Esse estudante é caracterizado por bons hábitos.

c. amxanag-eb-i a-xar-eb-en ertmanet-s

colega-PL-NOM VPR-fazer-ST-3ANOM.PL um.ao.outro-DAT

Os amigos fazem uns aos outros felizes.

c'. amxanag-eb-s a-xar-eb-t ertmanet-is ambeb-i

colega-PL-DAT VPR-fazer-ST-PL.DAT um.ao.outro-GEN notícias-NOM

Os amigos estão felizes com as notícias um do outro (lit. "as notícias um do outro fazem os amigos felizes").

d. es gogo-eb-i ertmanet-s a-int'eres-eb-en zghap'r-eb-it essa garota-PL-NOM um.ao.outro-DAT VPR-interessar-ST-3ANOM.PL conto-PL-INST Essas garotas estão interessando uma a outra em contos.

d'. am gogo-eb-s ertmanet-i a-int'eres-eb-t essa garota-PL-DAT um.ao.outro-NOM VPR-interessar-ST-PL.DAT

Essas garotas estão interessadas uma na outra.

[Adaptados de Tuite (1998)]

Seção 4.1.1 - p. 53

(23) Verbos direto-indiretos de Classe I 
a. mariam-i a-cxel-eb-s c'q'al-s

Maria-NOM VPR-esquentar-ST-3ANOM.SG água-DAT

Maria está esquentando a água.

a'. avadmq'op-s a-cxel-eb-s

paciente-DAT VPR-esquentar-ST-3ANOM.SG

O paciente está com febre.

[Adaptados de Tschenkeli (1958)]

\section{Seção 4.2 - p. 60}

(24) Causativos sem agente facultativos

a. shish-ma isev a-m-a-k'ank'al-a medo-ERG novamente PV-1B.SG-PRV-tremer-3AERG.SG.AOR.INDIC

$\mathrm{O}$ medo me fez tremer novamente.

a'. siciv-isa-gan a-m-a-k'ank'al-a

frio-GEN-POSP PV-1BDAT.SG-VPR-tremer-3ANOM.AOR.INDIC

Eu tremi de frio.

[Adaptados de Tuite (2009)]

\section{Seção 4.2 - p. 60}

(25) Causativos sem agente facultativos

a. me m-a-caxcax-eb-s rodesac v-uqur-eb

1SG.DAT 1BDAT.SG-VPR-ter.medo-ST-3ANOM.SG quando 1ANOM.SG-olhar-ST lom-S

leão-DAT

Eu tenho medo quando olho para um leão.

b. chem-s sul-s a-trtol-eb-s shen-i siqvarul-i

meu-DAT alma-DAT VPR-tremer-ST-3ANOM.SG seu-NOM amor-NOM

Minha alma treme por seu amor.

c. me m-a-bod-eb-d-a rodesac m-kond-a

1SG.DAT 1BDAT.SG-VPR-delirar-ST-SA-3ANOM quando 1BDAT.SG-ter-3ANOM

sicxe

febre.NOM

Eu delirava quando tive febre. 
Seção 4.2 - p. 60

(26) Verbo causativo sem agente em (a) e verbo ativo em (a')

a. ga-m-a-zmor-eb-s

PV-1BDAT.SG-VPR-alongar-ST-3ANOM.SG

Eu sinto a necessidade de me alongar.

a'. ga-v-i-zmor-e

PV-1AERG.SG-VPR-alongar-AOR.INDIC

Eu me alonguei.

\section{Seção 4.2 - p. 61}

(27) Marcação de caso em verbos indireto-causativos monovalentes e bivalentes.

a. xazarula-s siciv-isa-gan a-zhrzhol-eb-s

xazarula-DAT frio-GEN-POSP VPR-tremer-ST-3ANOM.SG

A xazarula (nome de árvore) estremece do frio.

a'. xazarula-s siciv-isa-gan she-a-zhrzhol-a

xazarula-DAT frio-GEN-POSP PV-VPR-tremer-3ANOM.SG.AOR.INDIC

A xazarula estremeceu do frio.

b. kal-s usiamovno mogoneba a-zhrzhol-eb-s.

mulher-DAT desagradável lembrança.NOM VPR-tremer-ST-3ANOM.SG

Uma lembrança desagradável faz a mulher tremer.

b'. kal-i usiamovno mogoneba-m she-a-zhrzhol-a.

mulher-NOM desagradável lembrança-ERG PV-VPR-tremer-3ANOM.SG.AOR.INDIC Uma lembrança desagradável fez a mulher tremer.

[Adaptados de Tuite (2009)]

\section{Seção 4.2 - p. 61}

(28) Verbos sem agente facultativos (não causativos)

a. ga-m-qin-av-s

PV-1BDAT.SG-sentir-se.gelado-ST-3ANOM

Eu me sinto gelado. 
b. gverd-shi m-chxvlet-s

lado-POSP 1BDAT.SG-sentir.dor-3ANOM

Eu sinto uma dor lancinante no lado do corpo.

\section{Seção 4.2 - p. 62}

(29) Causativos sem agente lexicais

a. c'amosvl-is dghe-s gaciebuli vq'opilvar, sashinlad partida-GEN dia-DAT resfriado 1SG.estar.PERF terrivelmente m-a-xvel-eb-d-a.

1BDAT.SG-VPR- tossir-ST-SA-3ANOM

No dia da partida eu fiquei resfriado, eu tossia terrivelmente.

a'. didi k'ac-ivit much'-shi v-a-xvel-eb grande homem-como palma-POSP 1ANOM.SG-VPR-tossir-ST Como um adulto eu tusso na minha mão.

b. mas da-a-xvel-a

3SG.DAT PV-VPR-tossir-3ANOM.AOR.INDIC

Ele tossiu.

[Adaptados de Tuite (2009)]

\section{Seção 4.2 - p. 62}

(30) Causativos sem agente lexicais

a. rac v-ch'am-e, gadmo-m-a-rc'q-i-a

que 1AERG.SG-comer-AOR.INDIC

PV-1BDAT.SG-VPR-vomitar-SM-3ANOM

Eu vomitei o que comi.

[Retirado de Rayfield (2006)]

a'. bavshv-ma gadmo-m-a-rc'q-i-a

criança-ERG PV-1BDAT.SG-VPR-vomitar-SM-3ANOM

A criança vomitou em mim.

\section{Seção 4.2 - p. 63}

(31) Causativos sem agente lexicais 
a. ertxel kimi-is lekcia-ze da-m-a-mtknar-a uma.vez química-GEN aula-POSP PV-1BDAT.SG-VPR-bocejar-3ANOM.AOR.INDIC Uma vez eu bocejei em uma aula de química.

a'. da-v-a-mtknar-e

[Adaptado de Tuite (2009)] PV-1AERG.SG-VPR-bocejar-AOR.INDIC

Eu bocejei intencionalmente.

[Adaptado de Hewitt (2005)]

\section{Seção 4.2 - p. 63}

(32) Causativos sem agente lexicais

a. zog-i haer-s iolad amo-a-boq'in-eb-s algum-NOM ar-DAT facilmente PV-VPR-arrotar-ST-3ANOM.SG Alguns bebês arrotam ar facilmente.

b. sisxl-i amo-v-a-Xvel-e sangue-NOM PV-1AERG.SG-VPR-tossir-AOR.INDIC Eu tossi sangue.

[Adaptados de Tuite (2009)]

\section{Seção 4.3 - p. 65}

(33) Verbo de Tipo 2 em (a) e verbo transitivo em (b)

a. is i-gin-eb-a (*mtavroba-s).

3SG.NOM PRV-xingar-ST-3ANOM.SG government-DAT

Ele fica xingando, está ocupado em xingar (*o governo).

a'. is

a-gin-eb-s mtavroba-s

3SG.NOM PRV-xingar-ST-3ANOM.SG

governo-DAT

Ele xinga o governo.

[Adaptados de Amiridze (2006)]

\section{Seção 4.3 - p. 65}

(34) Verbos de Tipo 2 
a. ras i-rt'q'mevin-eb-i?!

por que VPR-bater-ST-2ANOM.SG

Por que você fica batendo?! [lit. por que você bate?]

b. k'argi-a, nu i-cingl-eb-i!

bom-COP NEG VPR-choramingar-ST-2ANOM.SG

É o bastante, pare de choramingar!"

c. sup-shi rat'om i-purtx-eb-it?

sopa-POSP por que VPR-cuspir-ST-2ANOM.PL

Por que você continua cuspindo na sopa?

d. shexe, rogor dga-s da i-ch'qit'-eb-a

olhar.IMP como ficar.3ANOM.SG e VPR-olhar.estupefato-ST-3ANOM.SG

Olhe como ele fica ali olhando estupefato.

e. is i-coxn-eb-a

3SG.NOM PRV-morder-ST-3ANOM.SG

Ele fica mastigando, mastiga continuamente [enfatiza a natureza repetitiva da ação de mastigar].

[Adaptados de Tuite (2002)]

\section{Seção 4.3 - p. 66}

(35) Verbo de Tipo 2 em (a) e (a') e verbo transitivo em (b)

a. chvil-i i-k'bin-eb-a.

criança-NOM PRV-morder-ST-3ANOM.SG

A criança morde (quando, por exemplo, a criança já está na fase de ganhar novos dentes e gosta de ficar mordendo alguma coisa). [Adaptado de Amiridze (2006)]

a'. dzaghl-i i-k'bin-eb-a.

cachorro-NOM PRV-morder-ST-3ANOM.SG

O cachorro morde.

b. chvil-i m-k'en-s

criança 1BDAT.SG-morder.3ANOM.SG

A criança me morde.

\section{Seção 4.3 - p. 66}


(36) Verbo depoente de Tipo 1 em (b), verbo passivo em (c) e verbo bitransitivo de Classe I em (a).

a. mdivan-i kal-s pul-s a-dzlev-s

secretária-NOM mulher-DAT dinheiro-DAT VPR-dar-3ANOM.SG

A secretária dá dinheiro à mulher

b. mdivan-i pul-s i-dzlev-a

secretária-NOM dinheiro-DAT VPR-dar-3ANOM.SG

A secretária está dando dinheiro.

c. kal-s pul-i e-dzlev-a

mulher-DAT dinheiro-NOM VPR-dar-3ANOM.SG

Dinheiro está sendo entregue à mulher.

[Adaptados de Tuite (2002)]

\section{Seção 4.3 - p. 67}

(37) Verbo depoente de Tipo 1.

a. k'orisp'ondent'-i i-uc'q'-eb-a raion-is axal ambeb-s correspondente-NOM VPR-transmitir-ST-3ANOM.SG região-GEN novo notícias-DAT O correspondente está transmitindo (transmite regularmente) as últimas notícias da região.

[Adaptado de Tuite (2002)]

\section{Seção 4.3 - p. 67}

(38) Verbo depoente de Tipo 3

a. dzaghl-i i-q'ep-eb-a

cachorro-NOM VPR-latir-ST-3ANOM.SG

O cachorro late toda hora, tem o hábito de ficar latindo (de forma inapropriada, desnecessária).

[Adaptado de Tuite (2002)]

\section{Seção 4.3 - p. 67}

(39) Verbo depoente de Tipo 3 absoluto em (a) e relativo em (b). 
a. p'at'ara dzaghl-i i-p'ranch'-eb-a.

pequeno cachorro-NOM VPR-flertar-ST-3ANOM.SG

$\mathrm{O}$ pequeno cachorro faz pose/graça.

b. $[\ldots]$ da aravis e-p'ranch'-eb-i.

e ninguém.DAT VPR-flertar-ST-2A.NOM.SG

[...] e você não flerta ninguém.

\section{Seção 4.4 - p. 69}

(40) Verbos comitativos em (a) e (b) e verbos de Classe III em (a') e (b').

a. me adamian-eb-s v-e-lap'rak'-eb-i

1SG.NOM pessoa-PL-DAT 1ANOM.SG-VPR-falar-ST-1ANOM.SG

Eu falo com as pessoas.

a'. ambav-ze lap'arak'-ob-s

fato-POSP falar-ST-3ANOM.SG

Ele fala sobre o acontecimento.

b. dzaghl-i tevz-s e-tamash-eb-a.

cachorro-NOM peixe-DAT VPR-brincar-ST-3ANOM.SG

O cachorro brinca com o peixe.

b'. nino k'argad tamash-ob-s

nino.NOM bem jogar-ST-3ANOM.SG

Nino joga bem.

\section{Seção 4.5 - p. 73}

(41) Em russo

a. Naša sobaka ne kusaet detej.

our dogNOM NEG bite3.SG.PRES childrenACC.PL

'Our dog doesn't bite people.'

b. Naša sobaka ne kusajet.sja

our dogNOM NEG bite3.SG.PRES. sja

'Our dog doesn't bite.' 
Seção 4.5 - p. 75

(42) Em to'aba'ita

a. Wane e laba-ta'i nau.

man 3sg.fact harm-tr $1 \mathrm{sg}$

'The man harmed me.'

b. Wane baa 'e kwai-laba-ta'i.

man that 3sg.fact depat-harm-tr

'The man harms (people), damages, destroys (things).'

(LICHTENBERK, 2007, p. 1560)

\section{Seção 5.2 - p. 83}

(43) Contraste entre verbo de Classe IV (a) e verbo transitivo de Classe I (b)

a. me uceb she-m-dzul-d-a

1SG.DAT de repente PV-1B.DAT.SG-odiar- PI-3ANOM.SG.AOR.INDIC

papa

mingau-NOM

Eu detestei o mingau inesperadamente (não pude controlar).

b. me uceb she-v-i-dzul-e papa

1SG.ERG de repente PV-1AERG.SG-VPR-odiar-AOR.INDIC mingau.NOM

Eu detestei logo o mingau (deliberadamente).

[Adaptados de Amiridze (2006)]

Seção 5.4.2 - p. 93

(44) Verbo indireto em (a) e (b) e verbo direto em (a') e (b')

a. sandro-s u-qvar-d-eb-a nino

Sandro-DAT VPR-amar-PI-ST-3ANOM.SG Nino.NOM

Sandro está se apaixonando por Nino (mesmo que não queira). 
a'. sandro i-quar-eb-s nino-s

Sandro-NOM VPR-amar-ST-3ANOM.SG Nino-DAT

Sandro está se apaixonando por Nino (e está fazendo de propósito).

b. me she-m-i-qvar-d-a

musik'a

1SG.DAT PV-1BDAT.SG-VPR-amar-PI-3ANOM.SG.AOR.INDIC música.NOM

Eu me apaixonei pela música (sem intenção).

b'. me she-v-i-qvar-e musik'a

1SG.ERG PV-1AERG.SG-VPR-amar-AOR.INDIC música.NOM

Eu me apaixonei pela música (intencionalmente).

\section{Seção 5.4.2 - p. 93}

(45) Verbo indireto de Classe IV em (a) e verbo direto de Classe I em (a').

a. beka-s e-smin-eb-a musik'a

Beka-DAT VPR-ouvir-ST-3ANOM.SG música.NOM

Beka está ouvindo música (mesmo que não queira ou não precise).

a'. beka u-smen-s musik'a-s

Beka-NOM VPR-ouvir-3ANOM.SG música-DAT

Beka está ouvindo música (e está fazendo intencionalmente).

b. mas mo-e-c'on-a simghera

3SG.DAT PV-VPR-gostar-3ANOM.SG canção.NOM

Ele gostou da música (sem intenção).

b'. man mo-i-c'on-a simghera

3SG.ERG PV-VPR-gostar-3ANOM.SG canção.NOM

Ele gostou da música (intencionalmente).

\section{Seção 5.4.2 - p. 94}

(46) Verbos de Classe I

a. mo-v-i-mk'vdarun-e

PV-1AERG.SG-VPR-fingir.de.morto-AOR.INDIC

Eu me fingi de morto.

b. mo-v-i-gizhian-e

PV-1AERG.SG-VPR-fingir.de.louco-AOR.INDIC

Eu me fingi de louco. 
c. mo-v-i-sulel-e

PV-1AERG.SG-VPR-agir.como.tolo-AOR.INDIC

Eu me passei por idiota, agi como um tolo.

d. mo-v-i-mdzinar-e

PV-1AERG.SG-VPR-fingir.domir-AOR.INDIC

Eu fingi que estava dormindo.

(cf., por exemplo, o verbo de Classe IV m-din- $a v-s$-'eu durmo')

[Adaptados de Asatiani (1998)]

\section{Seção 5.4.2 - p. 94}

(47) Verbos desiderativos

a. m-e-mgher-eb-a

1BDAT.SG-VPR-cantar-ST-3ANOM

Eu sinto desejo de cantar, estou no humor de cantar.

b. m-e-cek'v-eb-a

1BDAT.SG-VPR-dançar-ST-3ANOM

Eu sinto desejo de dançar.

c. m-e-cin-eb-a

1BDAT.SG-VPR-dançar-ST-3ANOM

Eu sinto desejo de rir.

[Adaptados de Asatiani (1998)]

(Compare com os correspondentes agentivos de Classe III v-mgher-i 'eu canto', $v$-cek'v$a v$ 'eu danço' e $v$ - $i$-cin- $i$ 'eu rio').

\section{Seção 5.4.2 - p. 95}

(48) Contraste de significado entre verbo nas Séries II do Aoristo em (a) e nas Séries III do Perfeito em (a').
a. me
a-v-a-shen-e
saxl-i
megobr-is-tvis
1SG.ERG PV-1AERG.SG-VPR-construir-AOR.INDIC casa-NOM
amigo-GEN-para
Eu construí uma casa para meu amigo (eu quis construir). 
a'. me a-m-i-shen-eb-i-a saxl-i

1SG-DAT PV-1BDAT.SG-VPR-construir-ST-SM-3ANOM.SG casa-NOM

Eu construí a casa. (aconteceu, eu não tinha razão para construir).

\section{Seção 5.4.2 - p. 95}

(49) Contraste de significado entre verbo nas Séries II do Aoristo em (a) e nas Séries III do Perfeito em (a').

a. davaleba ar da-v-c'er-e tarefa.NOM não PV-1AERG.SG-escrever-AOR.INDIC

Eu não escrevi a tarefa (minha vontade, deliberadamente).

a'. davaleba ar da-m-i-c'er-i-a tarefa.NOM não PV-1BDAT.SG-VPR-escrever-SM-3ANOM.SG

Eu não escrevi a tarefa (involuntário, não deliberadamente, forçado).

[Adaptados de Asatiani (1998)]

\section{Seção 5.4.3 - p. 108}

(50) Verbo de Classe I em (a) e verbo indireto de Classe II em (a'), e contraste entre os dois em (b).

a. ga-m-i-t'ex-a man me is PV-1BDAT.SG-VPR-quebrar-3ANOM.SG.AOR.INDIC 3SG.ERG 1SG.DAT 3SG.NOM Ele quebrou isso para mim.

a'. ga-m-i-t'qd-a is me PV-1BDAT.SG-VPR-quebrar-3ANOM.SG.AOR.INDIC 3SG.NOM 1SG.DAT $\mathrm{Eu}$ (dat.) quebrei isso.

b. ch'ika k'i ar ga-v-t'ex-e, ucabedad vidro.NOM apenas não PV-1AERG.SG-quebrar- AOR.INDIC de repente ga-m-i-t'qd-a PV-1BDAT.SG-VPR-quebrar-3ANOM.SG.AOR.INDIC

Eu não apenas quebrei o vidro, eu (dat.) de repente o quebrei. 


\section{Seção 5.4.3 - p. 108}

(51) Verbo de Classe I em (a'), (b'), (c') e verbo indireto de Classe II em (a), (b), (c) e (e) e contraste entre os dois em (d).

a. dzalian bevri pul-i da-m-e-xarj-a muito muito dinheiro-NOM PV-1BDAT.SG-VPR-gastar-3ANOM.SG.AOR.INDIC Eu fiquei sem dinheiro (apesar de minha vontade, eu não tive intenção).

a'. bevri pul-i da-v-xarj-e muito dinheiro-NOM PV-1AERG.SG-gastar-AOR.INDIC $\mathrm{Eu}$ gastei muito dinheiro.

b. bavshv-s v-a-seirn-eb-d-i da criança-DAT 1ANOM.SG-VPR-levar.para.passear-ST-SA-SM e c'a-m-e-kc-a PV-1BDAT.SG-VPR-cair-3ANOM.SG.AOR.INDIC

Eu levei a criança para passear e a deixei cair (de forma inesperada, apesar de minha vontade).

b'. chemi brali-a, bavshv-i me c'a-v-a-kci-e minha culpa-COP criança-NOM 1SG.ERG PV-1AERG.SG-VPR-cair-AOR.INDIC É minha culpa, eu derrubei a criança.

c. me shemo-m-a-k'vd-a 1SG.DAT PV-1BDAT.SG-VPR-matar-3ANOM.SG.AOR.INDIC Eu matei (aconteceu, eu não tive intenção).

c'. me mo-v-k'al-i 1SG.ERG PV-1AERG.SG-matar-AOR.INDIC Eu matei (eu planejei e matei).

d. k'i ar ga-v-lax-e, shemo-m-e-lax-a apenas não PV-1AERG.SG-bater-AOR.INDIC PV-1BDAT.SG-VPR-bater-3ANOM.SG.AOR.INDIC Eu não apenas bati, eu (dat.) bati nele sem ter intenção. 

e. me shemo-m-e-landzgh-a chem-i
1SG.DAT PV-1BDAT.SG-VPR-insultar-3ANOM.SG.AOR.INDIC 1POSS.SG-NOM
tav-i
mesmo-NOM

Eu insultei a mim mesmo sem intenção. [Adaptado de Amiridze (2006)]

\section{Seção 5.4.3 - p. 110}

(52) Verbo de Classe I em (b) e verbo indireto de Classe II em (b'), e contraste entre os dois em (a).

a. k'i ar she-v-cham-e, shemo-m-e-cham-a apenas não PV-1AERG.SG-comer-AOR.INDIC PV-1BDAT.SG-VPR-comer3ANOM.SG.AOR.INDIC

Eu não apenas comi, eu comi sem ter intenção, sem querer. [Adaptado de Asatiani (1998)]

b. bavshv-eb-i cham-en vashl-eb-s

criança-PL-NOM comer-3ANOM.PL maça-PL-DAT

As crianças estão comendo maças.

b'. bavshv-eb-s e-chmev-a-t vashl-eb-i

crianças-PL-NOM VPR-comer-3ANOM-PL.DAT maça-PL-NOM

As crianças estão comendo maças (e.g., apesar de as crianças não terem permissão para comer as maças, não puderam resistir e estão comendo mesmo assim).

\section{Seção 5.4.3 - p. 110}

(53) Verbo de Classe I em (a) e (b) e verbo indireto de Classe II em (a') e (b').

a. me c'amo-m-cd-a

1SG.DAT PV-1BDAT.SG-dizer-3ANOM.SG.AOR.INDIC

Eu disse (eu não queria dizer, escapou).

a'. me v-tkv-i

1SG.ERG 1AERG.SG-dizer-AOR.INDIC

Eu disse (eu tinha uma razão para dizer algo). 
b. mas a-e-ri-a saxel-eb-i

3SG.DAT PV-VPR-confundir-3ANOM.AOR.INDIC

nome-PL-NOM

Ele confundiu os nomes (não tinha a intenção).

b'. man a-u-ri-a

3SG.ERG PV-VPR-confundir-3ANOM.AOR.INDIC nome-PL-NOM

Ele confundiu os nomes (intencionalmente).

\section{Seção 5.4.3 - p. 110}

(54) Verbos de Classe III e oscilação na marcação de caso.

a. macivr-i-dan c'q'al-ma i-c'vet-a

geladeira-INST-POSP água-ERG VPR-pingar-3A.SG.AOR.INDIC

A água pingou da geladeira.

b. macivr-i-dan c'q'al-i i-c'vet-a

geladeira-INST-POSP água-NOM VPR-pingar-3ANOM.SG.AOR.INDIC

A água pingou da geladeira.

[Adaptados de Harris (1981)] 